\title{
Acute liver ischemia : an experimental study in dogs with special emphasis on enzymatic and metabolic aspects
}

Citation for published version (APA):

Oostenbroek, R. J. (1986). Acute liver ischemia : an experimental study in dogs with special emphasis on enzymatic and metabolic aspects. [Doctoral Thesis, Maastricht University]. Rijksuniversiteit Limburg. https://doi.org/10.26481/dis.19861219ro

Document status and date:

Published: 01/01/1986

DOI:

10.26481/dis.19861219ro

Document Version:

Publisher's PDF, also known as Version of record

Please check the document version of this publication:

- A submitted manuscript is the version of the article upon submission and before peer-review. There can be important differences between the submitted version and the official published version of record.

People interested in the research are advised to contact the author for the final version of the publication, or visit the DOI to the publisher's website.

- The final author version and the galley proof are versions of the publication after peer review.

- The final published version features the final layout of the paper including the volume, issue and page numbers.

Link to publication

\footnotetext{
General rights rights.

- You may freely distribute the URL identifying the publication in the public portal. please follow below link for the End User Agreement:

www.umlib.nl/taverne-license

Take down policy

If you believe that this document breaches copyright please contact us at:

repository@maastrichtuniversity.nl

providing details and we will investigate your claim.
}

Copyright and moral rights for the publications made accessible in the public portal are retained by the authors and/or other copyright owners and it is a condition of accessing publications that users recognise and abide by the legal requirements associated with these

- Users may download and print one copy of any publication from the public portal for the purpose of private study or research.

- You may not further distribute the material or use it for any profit-making activity or commercial gain

If the publication is distributed under the terms of Article 25fa of the Dutch Copyright Act, indicated by the "Taverne" license above, 


\section{ACUTE LIVER ISCHEMIA}

An experimental study in dogs with special emphasis on enzymatic and metabolic aspects 



\section{ACUTE LIVER ISCHEMIA \\ An experimental study in dogs with special emphasis on enzymatic and metabolic aspects}

\section{PROEFSCHRIFT}

ter verkrijging van de graad van doctor in de geneeskunde aan de Rijksuniversiteit Limburg te Maastricht, op gezag van de Rector Magnificus, Prof. Dr. F.I.M. Bonke, volgens besluit van het College van Dekanen, in het openbaar te verdedigen in de aula van de universiteit op vrijdag 19 december 1986, des namiddags te twee uur

door

ROBERT JOANNES OOSTENBROEK

geboren te Brisbane (Australië) 
Promotor:

Co-promotores: Dr. W.Th. Hermens

Referenten:
Dr. P.B. Soeters

Prof. Dr. J.M. Greep

Prof. Dr. F.T. Bosman

Prof. Dr. J.A. Flendrig

Prof. Dr. J.H.P. Wilson

Financial support for the publication of this thesis was received from: Travenol B.V.

Auto Suture Benelux B.V. 
To my parents 



\section{List of abbreviations}

$\begin{array}{ll}\text { AA } & \text { Amino acids } \\ \text { AAA } & \text { Aromatic amino acids } \\ \text { Ala } & \text { Alanine } \\ \text { ALT } & \text { Alanine aminotransferase } \\ \text { AST } & \text { Aspartate aminotransferase } \\ \text { AV } & \text { Arterial-venous difference } \\ \text { A-fV } & \text { Arterial-femoral venous difference } \\ \text { BCAA } & \text { Branched chain amino acids } \\ \text { Cs } & \text { Steady state plasma activity } \\ \text { cAST } & \text { Cytoplasmic aspartate aminotransferase } \\ \text { C (t) } & \text { Enzyme activity present in plasma at time } t \\ \text { CK } & \text { Creatine kinase } \\ \text { E (t) } & \text { Extravascular enzyme activity at time } t \\ \text { ERR } & \text { Extravascular return rate constant } \\ \text { FCR } & \text { Fractional catabolic rate constant } \\ \text { GLDH } & \text { Glutamate dehydrogenase } \\ \text { GIn } & \text { Glutamine } \\ \text { HBD } & \text { Alpha-hydroxybutyrate dehydrogenase } \\ \text { IRG } & \text { Immunoreactive glucagon } \\ \text { IRI } & \text { Immunoreactive insulin } \\ \text { mAST } & \text { Mitochondrial aspartate aminotransferase } \\ \text { PCS } & \text { Portacaval shunt } \\ \text { Q (t) } & \text { Cumulative release of enzyme per litre of plasma at time } t \\ \text { TER } & \text { Transcapillary escape rate constant }\end{array}$




\section{Contents}

Chapter 1: Introduction and background of the study

Chapter 2: $\quad$ Survey of experimental vascular induced liver injury in dogs

2.1. Need for appropriate animal models

2.2. Extrahepatic vascular anatomy in dogs

- Arterial blood supply

- Portal and hepatic veins

2.3. Extrahepatic vascular surgery in dogs $\quad 10$

- Occlusion of the portal vein 11

- Occlusion of the common hepatic artery 12

- Occlusion of the portal vein and the common hepatic artery

- Portacaval shunt and occlusion of the common hepatic artery

Chapter 3: Methods for the assessment of the effects of normothermic hepatic ischemia in dogs

3.1. Introduction

3.2. Animals

3.3. Selection of anesthesia

3.4. Surgical procedures

3.5. Liver biopsies

3.6. Analytical methods

3.7. Quantitation of liver injury 24

3.8. Statistics

Chapter 4:

Arterial hepatic blood flow in dogs after a portacaval shunt and devascularization of the liver

4.1. Introduction

4.2. Measurement of arterial blood flow in the liver 27

4.3. Results

4.4. Discussion 
Chapter 5: Metabolic parameters in acute liver ischemia in dogs

5.1. Introduction

5.2. Material and methods $\quad 35$

5.3. Results 36

- Pilot study 36

- Definitive experiment 37

- Glucose, insulin and glucagon 37

- Epinephrine and norepinephrine . 40

- Amino acids 42

- Ammonia 54

- Lactate and pyruvate 55

- Free fatty acids and total ketone bodies: aceto-acetate and beta-hydroxybutyrate $\quad 57$

5.4. Discussion 58

Chapter 6: Enzymatic and pathological aspects of acute hepatic ischemia in dogs

6.1. Introduction

6.2. - Enzymatic patterns of acute hepatic ischemia 67

- Enzymatic quantitation of acute liver injury $\quad 69$

6.3. Pathological aspects of acute hepatic ischemia 73

6.4. Discussion 76

Chapter 7: Liver damage as a potential source of error in estimation of myocardial infarct size from plasma creatine kinase activity

7.1. Introduction

7.2. Material and methods $\quad 79$

7.3. Results 81

7.4. Discussion 86

Summary and conclusions $\quad 91$

Samenvatting en conclusies $\quad 95$

References $\quad 99$

$\begin{array}{ll}\text { Nawoord } & 109\end{array}$

$\begin{array}{ll}\text { Curriculum vitae } & 111\end{array}$ 



\section{Introduction and background of the study}

Little is known about the prevention or treatment of hepatic injury due to ischemia or shock. Abnormalities of hepatic function and morphology as observed in hepatic diseases, but also in diseases not primarily of hepatic origin, have often been associated with hepatic ischemia. Because of its high metabolic activity the hepatic cell is easily damaged by anoxia. Studies on the pathogenesis of liver insufficiency in ischemia deal mainly with isolated liver perfusion techniques or devascularization procedures with or without a portalsystemic shunt. However, all these laboratory models have their limitations. In the extensive literature, the wide variation in approach to animal experiments is striking.

Our main goal for the study was to assess a reproducible model of acute liver ischemia in the dog and to provide a detailled description of the characteristics of the model (chapter 3). Such a model necessitates the creation of a portalsystemic shunt, because prolonged portal occlusion leads to death within half an hour. Potential additional influences of the shunt itself should however be taken into account (Burchell, 1976). The details of devascularization procedures vary remarkably in different reports (chapter 2). The study in dogs of Farkouh (1971), Misra (1972), MacKenzic (1975 and 1977) have revealed that the survival rate after 60 to 90 minutes of hepatic ischemia ranged between $0-40 \%$. These authors performed a devascularization procedure of the liver with exception of the common hepatic artery, but including the construction of a portalsystemic shunt.

When trying to reproduce their procedures, we noted prolonged survival times if we carried out the occlusion of the common hepatic artery after one week. Either the devascularization employed during the surgical procedures was inappropriate or restoration of portal blood flow through collaterals was achieved within one week after our procedure. Both possibilities were therefore studied. The occurrence of retrograde blood flow and development of collateral circulation after installment of a portacaval shunt and ligation of the common hepatic artery was investigated by means of microspheres (chapter 4 ).

Death after prolonged acute liver ischemia is probably due to several 
metabolic abnormalities. We have looked for indices of the metabolic disturbances that could possibly be of prognostic value. From a metabolic point of view, portacaval shunted dogs have been well defined by many authors (Aguirre, 1974; Fischer, 1976; Soeters, 1977 and 1979). In clamping studies of the arterial afferent blood supply " however, in combination with a previously constructed portacaval shunt, detailed metabolic sequential studies are lacking. In our efforts to create a reproducible model of acute liver ischemia, we were interested in glucose and amino acid metabolism during and shortly after occlusion. In addition we were interested which metabolic determinants coincide with survival and which determinants may have prognostic value in non-survival (chapter 5).

When we consider the pathological features caused by the occlusion in our dogs, we have to take into account the effects of systemic diversion of portal blood on hepatocellular function and structure. There are only a few studies in dogs reporting acute and chronic histological changes of the liver after different periods of total ischemia. Edgcomb (1984) described that diversion of portal flow results in demonstrable morphologic liver changes. These changes are maximal 3 to 6 weeks postoperatively. For this reason, one week after performing the portacaval shunt and the devascularization procedure, the arterial inflow was occluded and biopsies were taken within 24 hours after occlusion. The effect of the temporary ischemia was followed in survivors, which were biopsied 2, 4 and 6 weeks later (chapter 6).

In the literature, controversy still exists whether histological changes occur before plasma enzymatic changes in liver injury. Concomitant with biopsies early after occlusion, plasma patterns of both mitochondrial and cytoplasmatic enzymes were measured. Analogous to the enzymatic quantitation of acute myocardial infarct size we have tried to quantitate the amount of liver injury. A two compartment model for the quantitative description of circulating proteins was used. This model is well established for enzyme release from the heart as well as from the liver (Hermens, 1982) (chapter 6).

The main part of this thesis concerns the characterization of an acute hepatic ischemic model in the dog, the quantitation of liver necrosis and the establishment of parameters that may predict outcome. Such a model, however, allows induction of acute complete liver ischemia with very little trauma, so that certain aspects of liver function can be assessed by studying the phenomena occurring after abolishment of all functions by the induction of ischemia. In chapter 7 , in this way a possible effect of liver function on the rate of elimination of creatine kinase (CK) from plasma was studied. Roberts (1975) demonstrated in dogs that subtotal occlusion of the hepatic 
artery did not influence the elimination rate of CK from plasma. It was concluded that the liver is not involved in this process. Recently, however, Carlson (1982) directly estimated hepatic extraction of CK from plasma and concluded that the liver is the main organ responsible for the elimination of CK. To settle this controversy, the effect of the complete arrest of hepatic blood supply on the rate of elimination of $\mathrm{CK}$ was measured in dogs with previous devascularization of the liver and a portacaval shunt (Oostenbroek, 1985a and 1985b). In addition the occurrence of liver damage in patients with uncomplicated acute myocardial infarction, was investigated by comparing cumulative plasma release of $\mathrm{CK}$, alpha-hydroxybutyrate dehydrogenase (HBD) and alanine aminotransferase (ALT) (chapter 7). 



\section{Survey of experimental vascular induced liver injury in dogs}

\subsection{Need for appropriate animal models}

Hepatic coma is a common occurrence in failing hepatic function and is the usual mode of death in patients with cirrhosis of the liver. Terminal stage hepatic insufficiency in the dog has many features in common with hepatic failure as seen clinically. Liver cell death is, obviously, a very important feature of the spectrum of the acute reaction of liver cells to injury. A wide variety of toxic chemicals, viruses and other hazards in the cell's environment, such as anoxia, are known to induce hepatic cell death. Several forms of hepatic injury have been shown to be associated with intracellular proteolysis. Clinical investigations have suggested that especially ischemia may be an important cause of this process, a possibility supported by observations in animals that experimental injury and shock cause a reduction of hepatic blood flow and histologic changes similar to those seen in patients with liver insufficiency (Brauer, 1963).

Experimental models of acute or chronic liver ischemia necessitate the construction of a portalsystemic shunt, to relieve associated portal hypertension or prevent the rapid development of portal congestion and shock. However such a shunt induces new pathophysiological mechanisms and these have to be elucidated (Alford, 1979). Potentially the anhepatic animal. would be a valuable model to study liver function, c.q. the absence of liver function. Total hepatectomy is, however, lethal within a day.

According to Terblanche (1975) and Miller (1976) a suitable animal model should meet the following criteria:

1. Reversibility: the hepatic failure induced should be potentially reversible.

2. Reproducibility: liver damage should be quantitatively and qualitatively reproducible.

3. Death from liver failure: a significant proportion of animals should die after a time-interval which is sufficiently long to allow treatment to be installed (de Groot, 1984).

4. Large animal model: a large animal should be used to allow the use of techniques applicable to human beings. 
5. Minimal hazard to personnel: drugs, micro-organisms or techniques used should be of minimal risk to laboratory personnel.

There is as yet no animal model which fulfills all criteria to allow evaluation of various methods of support applied in acute hepatic failure. According to the propositions made by Terblanche suitable models for studying fulminant hepatic failure have been produced in smaller animals like rats and rabbits, but a satisfactory larger animal model, e.g. in dogs, pigs and baboons, is not yet available. Carbon tetrachloride, paracetamol, galactosamine, dimethylnitrosamine, halothane, fluroxene and thioacetamide have been frequently used to produce experimental hepatic failure, mostly in rats. All these substances have been applied to dogs or pigs without satisfactory results. Liver ischemia has been claimed to be involved at least to some degree after severe trauma, infections, haemorrhage and a number of toxic lesions. It is therefore most likely that liver damage induced by acute ischemia in larger animals is a relevant model for hepatic failure in man.

\subsection{Extrahepatic vascular anatomy in dogs}

The liver receives most of its blood from the proper hepatic arteries branches of the common hepatic artery - and from the portal vein which is the confluence of the superior mesenteric, inferior mesenteric and the gastrosplenic vein. In all vertebrates blood from the alimentary canal traverses the liver, passing through a second capillary bed, before entering the systemic circulation. By controlling the outflow of blood from the liver, the hepatic veins are in a position to exert profound influence on liver function and portal hemodynamics. Although approximately $70 \%$ of the blood supply to the liver is supplied by the portal vein and only $30 \%$ by the hepatic artery, early investigators noted that the artery has an essential function in nourishing this large organ, because arterial blood is delivered at high pressure and fully oxygenated. The extrahepatic afferent and efferent blood supply will be discussed in detail in order to explain the devascularization procedures used in the present study.

\section{Arterial blood supply}

Early studies in the dog on the arterial course of the common hepatic artery and its hepatic branches, the proper hepatic arteries, are often inexact because they follow too closely the classic course and branching of the 
hepatic arteries in man. Grävenstein (1938), Tanturi (1950) and Popper (1954) have described the branching of the common hepatic artery more precisely but the most detailled investigation in this field was a study of Payer (1956), who reported data on 100 mongrel dogs of different age, sex and weight. After preparation of the abdominal aorta and the celiac trunk Payer considered: diameter and length of the common hepatic artery, its branching pattern, course and destination of the branches, and also the diameter of the splenic, left gastric, gastroduodenal and right gastric arteries. Before discussing the details of this extensive study concerning the hepatic arterial blood supply, the subphrenic origin as part of the arterial blood supply to the liver has to be mentioned.

In his original work, Popper (1954) confirmed results of Markowitz (1949) and emphasized the existence of hepatic branches of the phrenic arteries. Oxygen supply by these branches allowed survival of many dogs with complete interruption of the entire subhepatic blood supply. This subphrenic arterial blood supply can comprise about $10 \%$ of the whole arterial blood supply of the liver and is crucial in the interpretation of the effects of devascularization procedures of the liver. In spite of these anatomical studies many authors do not mention the branches of the phrenic arteries in their description of devascularization techniques. Some consequences of the presence of these phrenic branches will be discussed below. The original study by Payer (1956) presents the following data on hepatic blood supply. The celiac trunk arises from the ventral surface of the abdominal aorta as its first visceral branch. The length of the trunk averages 21.3 $\mathrm{mm}$, with an external diameter of $5.2 \mathrm{~mm}$. The celiac trunk trifurcates in 63 percent of cases in a typical triad: the common hepatic artery, the splenic artery and the left gastric artery (Fig. 2.2-1). In 34 percent of cases there is a combined gastrosplenic trunk. In these dogs the celiac trunk has four branches: common hepatic, splenic and two left gastric arteries. Sporadically the phrenic artery also originates from the celiac trunk. Mean external diameters of common hepatic, splenic and left gastric arteries are $3.4,3.4$ and $2.3 \mathrm{~mm}$, respectively. According to Payer, the common hepatic artery originates directly from the celiac trunk. The mean length is $56.8 \mathrm{~mm}$. From its origin the artery bends to the right and runs into the porta hepatis after reaching the antimesenteric rim of the duodenum. In the porta hepatis it forms caudally a concave arch, from which originate two to five proper hepatic arteries. The last branch lies left and caudally to the portal vein. The mean distance between the first and the last branch is $18.3 \mathrm{~mm}$. In the course of the celiac trunk to the first branch the common hepatic artery generally has no larger branches. Payer found one or two very small branches to the portal lymph nodes in 12 of the 100 dogs. 
Fig. 2.2-1

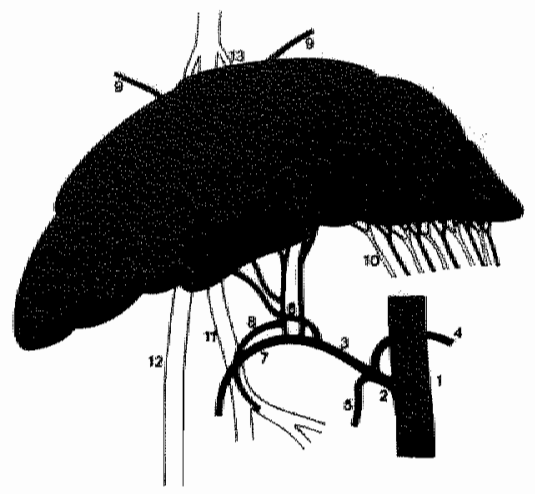

Fig. 2.2-2

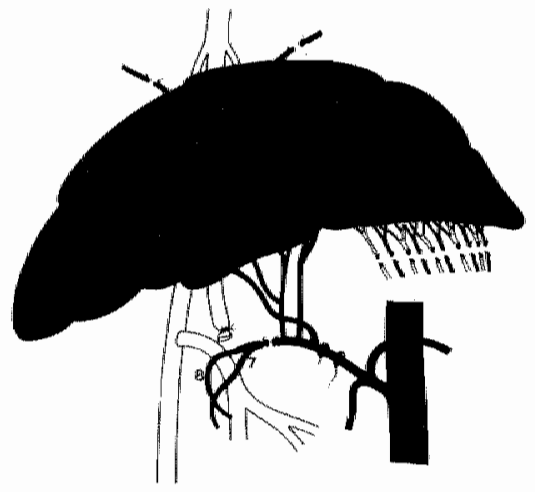

Fig. 2.2-3

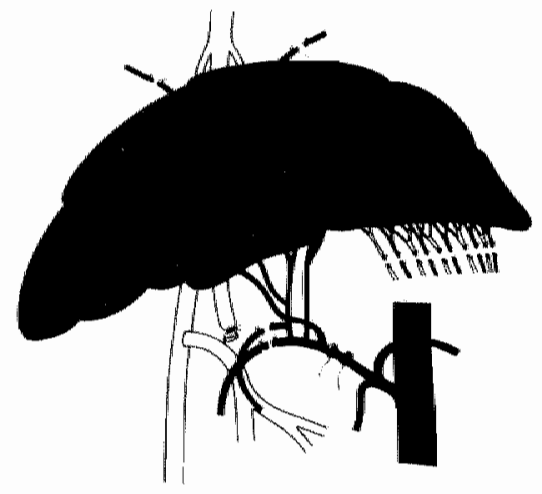

Hepatic circulation before and after hemodynamic intervention
1. Aorta
2. Celiac trunk
3. Common hepatic artery
4. Splenic artery
5. Left gastric artery
6. Proper hepatic arteries
7. Gastroduodenal artery
8. Right gastric artery
9. Hepatic branches of the phrenic artery
10. Small vessels in gastrohepatic ligament
11. Portal vein
12. Vena cava inferior
13. Hepatic veins 
The right gastric artery arises mostly from the common hepatic artery (fig. 2.2-3). If not, it arises from one of the proper hepatic arteries, in which case the common hepatic artery becomes the gastroduodenal artery after the last proper hepatic artery (fig. 2.2-1). In the first instance the common hepatic artery terminates as the small right gastric and the much larger gastroduodenal artery. The origin of the branches to the liver and the right gastric artery in the hilus demonstrate a large variability (Fig. 2.2-2 and fig. 2.2-3).

At least two and at most five branches of the common hepatic artery lead to the liver. The single branches often fuse, from which new branches run to the hepatic lobes. The sequence of ramification of the single hepatic branches exhibits a wide variability. As one would expect, no uniform nomenclature exists. Payer named every branch according to its supply area: ramus lobi caudati, ramus lobi sinistri, ramus processus papillaris, ramus lobi quadrati, ramus lobi dextri medialis, ramus lobi dextri lateralis and cystic artery. As we found mostly three proper hepatic arteries in our own experiments we adopted for convenience the nomenclature given by Miller (1964). The right branch goes to the right portion of the liver, the caudate and right lateral lobes. The middle branch goes to the right medial lobe, dorsal part of the quadrate, and part of the left medial lobe. This artery may be replaced by two or more arteries. The left branch, shortest of the three, supplies the large left lateral lobe, the quadrate lobe, and part of the left medial lobe. From this branch the cystic artery arises. This vessel leaves the left branch about $10 \mathrm{~mm}$ before it enters the liver, and ramifies into two or more branches primarily on the surface of the gallbladder which is attached to the liver.

The origin and course of the right gastric artery is very variable. Payer described a mean diameter of only $1.1 \mathrm{~mm}$. In 45 percent the artery arises at the same level as the hepatic branches. In 25 percent the origin is situated 3-28 $\mathrm{mm}$ distally from the last hepatic branch. The right gastric artery originates in 18 percent from the proper right branch. In the remaining dogs the artery arises from other hepatic branches. If the right gastric artery does not exist the left gastric artery supplies the whole minor curvature of the stomach. The continuation of the common hepatic artery is the gastroduodenal artery with a mean diameter of $2.7 \mathrm{~mm}$, much larger than the right gastric artery. Although many observations in the literature describe the additional variations in the arterial blood supply to the liver, our own results have largely supported those of Payer.

\section{Portal and hepatic veins}

The portal venous sytem is interposed between two capillary beds, draining 
the gastrointestinal tract and emptying into the capillary network of the liver. The portal vein drains blood from the splanchnic area and is formed as an upward continuation of the superior mesenteric vein after this vessel has been joined by the splenic vein. The vein then runs caudodorsal to the pancreas and posterior in the hepatoduodenal ligament. At the porta hepatis the portal vein divides into right and left branches which run with the hepatic arteries and the right and left hepatic ducts. In the center of the hepatic lobules there are single central veins. These constitute the beginning of the efferent or outgoing venous system of the liver. Adjacent central veins fuse to form the interlobular veins, which unite to form the hepatic veins.

Swelling of the canine liver can be produced by several experimental interventions or pathollogical conditions. This swelling is thought to be due to changes in the outflow of blood from the liver as a result of contraction of hepatic venous sphincters. Bauer (1932) already reported a possible sphincter action at the junction of the hepatic vein with the inferior caval vein. Deysach (1941) reported the mechanism at sublobular vein level, while Knisely (1957) demonstrated sphincter action at the sinusoidal level. Moreno (1962) stated that the blood reservoir function of the canine liver is supported by the unique ability of the hepatic veins to store blood. They demonstrated that epinephrine was the specific agent controlling the hepatic vein sphincters. Alternatively, the whole hepatic venous system may react by vasoconstriction (Neill, 1963). Arterioportal connections may provide functional shunts between the two systems by enabling blood to pass from the high-pressure arterial inflow system to the low-pressure portal venous system and provide a possible explanation of some of the interrelationships between the arterial and portal venous inflow into the liver (Richardson, 1981).

\subsection{Extrahepatic vascular surgery in dogs}

In order to study the effects of interruption of the afferent blood supply to the liver, occlusion of the hepatic vessels has received a great deal of attention. Since Malpighi (1699) (Markowitz, 1949) first ligated the hepatic artery much controversial evidence has been submitted. Some authors stated that ligature of the hepatic artery is without effect while others maintain that necrosis of the liver follows. The surgical trauma in itself may play an important role. Haberer (1906) stated, for instance, that occlusion of the hepatic artery beyond the origin of the right gastric artery results in 
extensive liver necrosis, while Markowitz (1949) and Tanturi (1950) found that under antibiotic therapy 100 percent of their dogs survived such ligature of the hepatic artery. Results of reports on the tolerance of the dog to temporary hepatic portal inflow obstruction also vary widely. To obviate rapid development of splanchnic congestion and shock after occlusion of the portal vein Raffucci and Wangensteen (1951) rendered the intestines ischemic by clamping the superior mesenteric artery and celiac axis. A reduced mortality rate has been reported by Goodall (1957) who used this technique also in combination with hypothermia. Drapanas (1955), Hines (1956) and many others used either a side-to-side or an end-toside portacaval shunt in order to escape splanchnic congestion. When the pathophysiology of temporary or permanent hepatic ischemia is considered four different possibilities of inflow obstruction can be distinguished:

* Occlusion of the portal vein;

* Occlusion of the common hepatic artery;

* Occlusion of the portal vein and the common hepatic artery;

* Portacaval shunt and occlusion of the common hepatic artery.

\section{Occlusion of the portal vein}

Interest in the duration of portal vein acclusion that can be tolerated stems from work on orthotopic canine liver homotransplantation. Occlusion of the portal vein in the dog and in rats above the last tributary, usually results in rapid deterioration and death (Onnis, 1962; Kerr, 1975; van Dongen, 1984). In man and in the monkey the intestines show considerable congestion, but recovery generally occurs. Apparently sufficient collateral circulation exists to permit an effective intestinal outflow. Probably, in the surviving subject this collateral flow develops quickly so that the induced portal hypertension subsides within a week or ten days.

Johnstone (1957) found a precipitous fall in blood pressure to 30 or $40 \mathrm{~mm}$ within 10 to 20 minutes after ligation of the portal vein in dogs. The estimated circulating blood volume was reduced by approxinately $56 \%$. After these studies and a review of the literature he stated that although the reduction in the circulating blood volume was a most important factor, death could not be solely attributed to this factor. Maynard Beach (1965) concluded that tissue ischemia and cellular anoxia in dogs produce severe lactic acidosis, which appears to be an important lethal factor accompanying hypotensive shock. Acute occlusion of the portal vein during 60 minutes results in severe distention of the larger mesenteric veins and progressive discoloration of the intestines with many scattered subserosal hemorrhages. Pulsations in the mesenteric arteries were promptly attenuated and after some minutes could no longer be observed. These phenomenal disappeared 
within several minutes after removal of the clamp. Nine out of ten dogs survived after 60 minutes of portal vein occlusion.

\section{Occlusion of the common hepatic artery}

In the past a great deal of controversial evidence has been put forward concerning hepatic artery ligation. This procedure has been recommended for various conditions, e.g. hepatic carcinoma, hepatic artery aneurysm, arterio-venous fistula, accidental hepatic arterial injury and bleeding from lacerations after trauma to the liver.

Previous experiments have shown that excision of the entire canine hepatic artery, from the celiac trunk up to the hilus of the liver, was well tolerated if antibiotics were given (Markowitz, 1949). Further work demonstrated that even without antibiotics, this procedure was not fatal in a substantial percentage of experiments. Raffuci (1951), Popper (1953), Alivisatos (1971), Jeppson (1979) and Hasselgren (1979) demonstrated that temporary or permanent occlusion of the common hepatic artery in dogs can be done safely. Raffucci (1951) found that occlusion of the hepatic artery for one hour was tolerated without demonstrable ill side effects. Popper (1954) stated that arterial blood entering the liver through the hepatic branches of the phrenic arteries was responsible for survival. Interruption of the entire arterial blood supply of the liver by complete excision of the hepatic artery and ligation of the hepatic branches of the phrenic arteries was generally fatal. Therefore the conclusion seemed justified that the oxygen provided by the portal blood alone is insufficient to prevent liver death. In his observations combined ligature of the hepatic artery with threefourths of the portal branches in the hilum of the liver leads to liver necrosis when performed in one stage. This procedure was well tolerated if performed with an interval of one week. He concluded that the liver can gradually adjust to a drastically reduced arterial and venous circulation. By clamping the common hepatic artery for only 60 to 75 minutes, Alivisatos (1971) found a decrease in systemic arterial pressure of 5 to $10 \mathrm{~mm} \mathrm{Hg}$. Thirty minutes after beginning of clamping, the oxygen saturation in the suprahepatic veins had decreased maximally, whereas the oxygen saturation in the portal vein increased progressively after clamping. This increased portal oxygen saturation was maintained during the whole experiment. Popper (1954) suggested that opening of arterio-venous anastomoses between the systemic circulation and the portal circulation at the level of the intestines was responsible for the increased oxygen saturation in portal blood. In pigs Jeppson (1979) investigated the effect on the liver parenchyma of periods of occlusion of the hepatic arterial circulation, of restoration of the arterial blood flow after several hours of occlusion and the significance 
of the interval between operation and occlusion. Two slings were used which were placed around the hepatic artery and its branches and distal to the gastroduodenal artery. With this method they could repeatedly interrupt the arterial supply to the liver for any length of time without anesthesia. In different groups of dogs the arterial supply was occluded for $1,2,4$ or $12 \mathrm{hr}$ on the 1 st and $3 \mathrm{rd}$ postoperative day. The authors stated that when the occlusion is transient, there is less stimulus for development of arterial collaterals. They were unable to explain why liver cells are damaged less when the interval between operation and occlusion is lengthened. Degradation products and toxic substances derived from the operative trauma can aggravate liver damage when occlusion is performed soon after the operation. It is also possible that after some days metabolic alterations in liver cells generate a resistance to liver ischaemia. In this respect it may be relevant that Hasselgren (1979) found a reduced incorporation rate of amino acids (e.g. ${ }^{14} \mathrm{C}$-leucine) into liver proteins after an ischemic period effected by ligation of the hepatic artery for 1 hour.

In conclusion, occlusion of the subhepatic arterial blood supply is at present considered less dangerous than was reported in early investigations.

\section{Occlusion of the portal vein and the common hepatic artery}

Simultaneous acclusion of the portal vein and of the hepatic artery rapidly results in death. In his original work Raffuci (1951) demonstrated that seven out of nine dogs died as a result of clamping subhepatic afferent blood supply for 30 minutes. The maximum time tolerated was in the vicinity of 20 minutes. In another series of experiments the afferent circulation was occluded for 15 minutes. The clamps were then released for 30 minutes and reapplied for 15 minutes. All dogs survived this procedure and none showed necrosis. With these experiments Raffucci (1951) confirmed the findings of Fitts (1950) and Lewis (1950). These experiments carried out in the early fifties are in agreement with the more recent operative results in man of Brunschwig (1955), Shumway (1956), Huggins (1957), Longmire (1961), MacKenzie (1977), and Huguet (1978). Also Popper (1953), confirming the results of Rapaport (1951) (Rappaport, 1973), stated that the liver of the dog appears to be able to survive a drastic reduction of its arterial and venous blood supply if this is done in stages. Obviously, for supply of oxygen, the hepatic artery is more important than the portal wein. A decreased portal blood flow, combined with some arterial blood perfusing the liver via an interval-clamped thepatic artery or through the hepatic branches of the phrenic arteries is sufficient to prevent liver necrosis.

Alivisatos (1971) occluded the complete subhepatic blood supply in 15 
dogs. Five were occluded for 5 minutes, another 5 for 45 minutes and 5 dogs for 60 minutes. In the first group no problems were encountered. From the group which were occluded for 45 minutes all dogs were dead within 20 days, while the third group did not survive 48 hours. Studying especially hemodynamies he demonstrated a point of no return in the two groups after 30 minutes which coincided with persistent pathological findings. Central-lobular necrosis, interstitial oedema, oedema in the hepatocytes with vacuolisation and hyperaemia in the portal regions were the main pathological features. With regard to total clamping of subhepatic blood supply, specifically the study of Kock (1972) has to be mentioned dealing with the interaction between the portal vein and hepatic artery. Separate electromagnetic flow probes and partial short-term occlusion were used in this study. The mean ratio between the flow through the portal vein and the hepatic artery was $3.5: 1$. Complete or partial occlusion of the hepatic artery for three to five minutes did not change the portal flow, while partial or total occlusion of the portal vein produced a rapid but transient increase in hepatic artery flow. After discontinuation of occlusion, reactive hyperemia was seen in the arterial flow bed but not in the portal venous bed. These experiments support the concept of hepatic arterial autoregulation with a fixed portal flow to the liver.

\section{Portacaval shunt and occlusion of the common hepatic artery}

In initial attempts to avoid venous infarction of the bowel during occlusion of both portal vein and hepatic artery occlusion the superior mesenteric artery and celiac axis were clamped. In these experiments the turning point between reversible and irreversible damage of liver parenchyma appeared to be between 30 to 40 minutes of clamping (Raffuci, 1951; Goodall, 1957). These authors and others have reported a markedly reduced mortality rate following one hour of occlusion when hypothermia was used (Huggins, 1957).

In later reports the combination of a portalsystemic shunt and occlusion of the hepatic artery was used more and more to assess the tolerance of the dog liver for prolonged warm ischemia and to study the late consequences of such an injury to the parenchyma of the liver.

In 1877, von Eck, a Russian military surgeon, carried out the first portacaval shunt by performing a side-ta-side anastomosis of the portal wein to the caval vein below the liver, with ligation of the portal wein above the last tributary. The fact that blood from the alimentary canal traverses the liver before entering the systemic circulation put the liver in a favourable position to exercise some censorship on the products of digestion before they enter the general circulation. Interest in metabolic 
implications combined with attempts to relieve portal hypertension has established portacaval anastomosis and other varieties of portalsystemic shunts as procedures studied by clinicians and investigators for more than a century.

In the early fifties Drapanas (1955) used a side-to-side portacaval shunt to avoid portal hypertension during complete interruption of inflow of portal and arterial blood to the liver. Sixteen out of 17 dogs survived 30 to 75 minutes of ischemia. Three out of 9 animals survived periods of 90 minutes but none survived a longer interval of interrupted circulation. Hines and Roncoroni (1956), also using a portacaval shunt to prevent intestinal congestion found that 9 out of 10 dogs died after 30 minutes of hepatic inflow interruption and 23 out of 24 died after one hour. Popper (1954) stressed the role of oxygen supply by the hepatic branches of the phrenic arteries. These investigations demonstrated for the first time the important role of these ramifications in occlusion studies. Prolonged survival was observed in dogs with a portalsystemic shunt and occlusion of the hepatic artery. The conclusion was drawn that the oxygen supply by these suprahepatic arterial branches helps to prevent liver necrosis. Restrepo (1962) determined changes of hepatic blood flow in normal dogs following side-to-side and end-to-side portacaval anastomosis. In addition he reported studies concerning dogs with an end-to-side portacaval anastomosis and splenectomy, with ligation of the hepatic artery and after 70 cent hepatectomy. Liver blood flow was estimated with radioactive colloidal gold. Surgical trauma itself did not significantly affect hepatic circulation. Portacaval shunted dogs had a decrease of total hepatic blood flow of approximately 50 per cent. A similar reduction was seen after side-to-side and end-to-side shunts indicating that there was no perfusion of sinusoids with portal blood after construction of side-to-side portacaval shunts. In the postoperative period the total hepatic blood flow decreased further in all dogs with portacaval shunts. Although there was no significant change in hepatic blood flow in animals with ligation of the hepatic artery, there was a high mortality due to liver necrosis. In a study by Swenson (1967) in dogs with a portafemoral shunt (teflon-silicone rubber shunt) and occlusion of the hepatic artery, permanent vascular changes were produced in the liver by ischemic periods of more than 90 minutes duration. The author concluded that ischemic periods of longer than four hours may result in irreversible loss of hepatocytes. In these experiments the hepatic branches of the phrenic arteries were not occluded, which may explain the higher survival rates compared with the study by Popper (1954).

The possibility that periarterial dissection leads to denervation of the hepatic artery which may augment liver blood flow has been investigated 
and thas led to broad controversy. In two groups of dogs Smith (1967) performed hepatic periarterial neurectomy by stripping the periadventitial tissues and accompanying splanchnic nerves from the hepatic artery over a distance of $20 \mathrm{~mm}$. In one group staged ligation of the portal vein was performed. Another group of dogs underwent a side-to-side portacaval shunt. Liver blood flows were estimated by the radioactive gold technique. After ligation of the portal vein liver blood flow decreased 56 per cent, while in combination with periarterial neurectomy there was a reduction in flow of only 33 per cent $(\mathrm{p}<0.001)$. After porta-caval shunt alone the liver blood flow was reduced by 54 per cent; in combination with neurectomy the postoperative flow fell by 40 per cent $(p<0.05)$. After clinical application in three patients with portal hypertension and bleeding esophageal varices, it was concluded that the use of hepatic periarterial neurectomy as an adjunct to portacaval shunt warranted further laboratory investigation and clinical trials. Several years later Mathie (1980) studied the influence of hepatic artery denervation and total liver denervation on the hepatic arterial flow after acute occlusion of the portal vein in dogs. Side-to-side mesocaval shunt provided drainage of the mesenteric venous blood. Occlusion of the portal vein produced an immediate and significant increase in hepatic arterial flow which was sustained at approximately $80 \%$ above control values during 6 minutes of observation. Total liver blood flow and hepatic tissue perfusion ( ${ }^{85} \mathrm{Krypton-clearance)}$ were both significantly reduced with approximately $40 \%$. Denervation of the hepatic artery alone or of the entire liver produced no change in the response, so that it was concluded that there is no neurogenic component either initiating or modifying the early changes in hepatic arterial flow.

In pigs Nordlinger (1980) cross clamped the portal triad for 60,90 , 120 and 180 minutes after achieving portal decompression by an external splenojugular shunt. The suprahepatic arteries were divided. After releasing the clamp the shunt was removed and the splenic vein was tied. Portal ischemia of the liver was confurmed by aortography and Au-liver scan. After two hours of ischemia the anatomic changes were mild. According to their protocol, 120 minutes can be considered as the maximal safe period of normothermic ischemia of the liver in pigs.

The variability of the experimental protocols and the experimental species used precludes clear conclusions. However it is apparent from these studies that the tolerance of the liver to warm ischemia varies considerably even within the same species and despite strict adherence to the protocol. Some unknown factors must be responsible for this larger variation between animals (Oostenbroek, 1982; de Boer, 1984 and 1986). 


\section{Methods for the assessment of the effects of normothermic hepatic ischemia in dogs}

\subsection{Introduction}

To circumvent repeated descriptions of methods employed in the chapters $4,5,6$ and 7 , containing the actual dog experiments, in this chapter materials, methods and techniques will be described in detail.

\subsection{Animals}

Experiments were carried out with overnight-fasted mongrel dogs (18-40 $\mathrm{kg}$ ) of either sex, that had been fed standard dog chow (Hope Farms, Woerden) for at least 10-14 days prior to the first stage surgical procedure. Water was allowed ad libitum. The dogs were examined by a veterinary surgeon. The animals had been observed and screened for parasites and other infections. The females were neither pregnant nor lactating. A leucocyte count below $16.10^{\circ} /$, a hematocrit above $38 \%$, a good appetite and normal stools, were required before experiments were started. The animals were housed in separate cages, in a constant temperature and humidity and with a normal day/night rhythm. Once a week and prior to the surgical procedure and the experiments the dogs were weighed.

\subsection{Selection of anesthesia}

Protection from stress is a major purpose of anesthesia. Many experiments demonstrate that a considerable central sympathetic activity exists during the anesthetic state produced by classical agents. In searching for the most suitable anesthesia for the occlusion experiments and to avoid disturbances of the hormone-related parameters, the so-called 'stress-free" anesthesia seemed advantageous. Recently there has been considerable interest in these techniques which appear to ameliorate some of the physiological and metabolic responses to surgery (Cooper, 1981; Zurick, 1981). In our experimental design we intended to follow chronologically the metabolic response, especially with regard to insulin, glucagon, epinephrine and 
norepinephrine, during and after acute liver ischemia. This requires anesthesia with a minimal endocrine and metabolic response and with maximal cardiovascular stability.

The increase in blood glucose concentration during anesthesia and surgery has been extensively investigated. Hall (1978) compared the effect of supplementation of nitrous oxide and oxygen anesthesia with either halothane or fentanyl on the metabolic and hormonal response in healthy women who were admitted for microscopic tubal surgery. The supplementation with fentanyl abolished the hyperglycemic response, and the cortisol and growth hormone response after surgery. Effects of anesthesia and surgical stress on endocrine function related to carbohydrate metabolism was investigated by Ohkubo (1979) in 73 patients who underwent abdominal surgery. Again halothane was compared with fentanyl in combination with nitrous oxide in oxygen. Blood glucose levels in both types of anesthesia increased slightly. Glucagon increased only in the initial phase in the fentanyl group, while levels of insulin, the catecholamines, growth hormone and cortisol did not vary significantly during both types of anesthesia.

De Castro (1979) investigated cardiovascular, neurological and metabolic side-effects of eight narcotics in dogs and found no metabolic acidosis and hypermetabolism after high and even massive intravenous doses of fentanyl. The recent interest in high dose fentanyl as a sole anesthetic agent to be used with oxygen during surgery stems from its remarkable ability to stabilize hormonal metabolic and cardiovascular responses. Whether alteration or blockade of the stress response to surgery is advantageous or not is a debatable point. Stanley (1980) demonstrated that fentanyl and oxygen prevent the increases in plasma concentrations of stress hormones, with the exception of significant increases in epinephrine and norepinephrine levels just after cardiopulmonary bypass in patients selected for coronary artery surgery. These results were confirmed by Sebel (1981) in his study on hormonal responses to high dose fentanyl anesthesia in cardiac surgery. No significant changes were demonstrated in blood glucose, insulin and growth hormone, while decreased cortisol concentrations were found both in controls and the high-dose-fentanyl group.

Although most studies of the effects of anesthetic agents on specific aspects of metabolism deal with patients who have debilitating diseases such as cardiac lesions, or consider some form of premedication or surgery, the general preference for a high-dose-fentanyl oxygen combination seems justified from a metabolic point of view (Editorial Lancet, 1979; Editorial Br. J. Anaesth., 1980). 


\subsection{Surgical procedures}

As discussed in the preceding chapter, both portal and arterial blood flow to the liver must be interrupted in order to produce acute ischemic damage. In addition, the portal inflow to the liver can only be interrupted after providing a shunt pathway for the portal blood. Taking these factors into account it was decided to produce hepatic ischemia by occlusion of the common hepatic artery after prior installment of a portacaval shunt. In order to separate the hormone-related metabolic disturbances induced by surgical trauma from those resulting from hepatic ischemia, a two-stage devascularization procedure was adopted. First, an end-to-side portacaval shunt was constructed and two inflatable ballloon occluders were placed around the hepatic artery. Thereafter, the animals were allowed to recover for at least a week before hepatic ischemia was produced by temporary inflation of the occluders. After reappraisal of anatomical details in the literature and after careful study of the hepatic vasculature in several dogs we concluded that three points were of major importance:

* A substantial arterial support by the hepatic branches of the phrenic arteries is often present.

* The liver may receive arterial support from vessels in the gastrohepatic omentum.

* Retrograde flow may occur from the gastroduodenal artery and the right gastric artery.

With respect to the last aspect retrograde flow in dogs from the right gastric artery, originating from a proper hepatic artery, together with retrograde flow from the gastroduodenal artery has not been described in the literature (Fig. 2.2-2 and 2.2-3). This phenomenon could be visualized with selective angiography of the celliac trunk and superior mesenteric artery. After occlusion of the common hepatic artery retrograde filling of the proper hepatic arteries was demonstrated, although somewhat delayed. Together with the subphrenic arterial blood supply, this retrograde flow appears to be crucial for survival after temporary liver ischemia (see chapter 4).

Taking these factors into account, the two-stage devascularization procedure was adlapted as follows:

First stage.

After an overnight fast (16-18 hr), dogs were premedicated with Acetadon " $0.1 \mathrm{ml} / \mathrm{kg}$ b.w. (pro $\mathrm{ml}: 0.6 \mathrm{mg}$ atropinosulfate, $4 \mathrm{mg}$ methadon- $\mathrm{HCl}$ and $1.5 \mathrm{mg}$ acepromazine) and received a pre-operative dose of $500 \mathrm{mg}$ ampicillin i.m. $\left(\right.$ Amfipen $\left.{ }^{\mathrm{R}}\right)$. Anesthesia was introduced with sodium pentobarbital 
$\left(10 \mathrm{mg} / \mathrm{kg}\right.$; Narcovet $\left.{ }^{k}\right)$, and the dogs were after endotracheal intubation connected to a ventilator. Anesthesia was maintained with nitrous oxide in oxygen while adjusting the fractional inspired oxygen concentration $\left(\mathrm{FiO}_{2}\right)$ to achieve an arterial partial pressure of oxygen $\left(\mathrm{pO}_{2}\right)$ of 80 to $100 \mathrm{~mm} \mathrm{Hg}$. This type of premedication and anesthesia allowed a quick recovery.

\section{Operative technique.}

Adhering to general rules of asepsis a midline upper abdominal incision is made with the use of a cautery. After the peritoneal cavity is opened, the fat pad is excised. The incision is widely retracted with a self-retaining retractor. After inspection of the entire abdomen, the small and large intestines are packed in a large moist towel and kept to the left abdominal side by the assistant's stretched left hand. This maneuver clearly exposes the portal vein and inferior vena cava. The gastrohepatic ligament at the most right outer edge and the ipsilateral hepatorenal ligament is incised. Connective tissue, fat and adventitia from the portal vein is carefully stripped on its free surface up to the portal bifurcation at the hilum. Special attention is made not to overlook the highest tributary vein. It is necessary to free the vena cava of overlying fat and connective tissue above the entrance of the renal veins, as cephalad as possible. A vesselloop is placed around the portal vein just caudal of its bifurcation. After these maneuvers the veins are freed to obtain sufficient mobility to construct an end-toside portacaval shunt. Before performing the shunt however, the hepatophrenic attachments have to be totally divided to interrupt any additional arterial blood supply. Starting at the extreme left margin of the left liver lobe these attachments are dissected to the right side. After dividing successively the left triangular ligament, sometimes present in duplicate, and the falciform ligament, the left margin of the hepatic veins is reached. By turning the dome of the right lobe to the left side with the surgeon's left hand, the right triangular and the coronary ligaments can be cut. The liver is suspended now only by the veins entering the vena cava and the structures in the right margin of the omentum minus. With this technique it is impossible to overlook the phrenic arteries at both sides of the hepatic veins. The phrenic arteries are ligated and divided on the surface of the diaphragm. In dissecting the liver from the surrounding structures any aberrant branch to the liver is interrupted. After ligation and division of all the structures in the gastrohepatic omentum left of the common bile duct, complete division is obtained of all hepatic ligaments containing the accessory arterial supply. The liver is now devascularized except for the portal vein and the hepatic artery. 
The common hepatic, the proper hepatic, the gastroduodenal and the right gastric arteries have to be carefully dissected. The hepatic artery is cleared from its origin to its final division, the gastroduodenal artery with or without the right gastric artery. When the right gastric artery originates from a proper hepatic artery it is interrupted at this site. Subsequently, independent of this last procedure, ligation and division of the common hepatic artery, named gastroduodenal artery at this point, is performed directly after the last branching proper hepatic artery. Around the common hepatic arteries two balloon occluders with a diameter of $3 \mathrm{~mm}$ are placed (Janssen Pharmaceutica, Beerse, Belgium), after testing their patency by inflating the balloons.

After this devascularization the portacaval shunt is constructed. The operation area and instruments are adjusted, the portal vein is clamped and ligated in the hilum of the liver and divided just below its bifurcation. With a clamp according to Satinsky the vena cava is partially clamped in a longitudinal direction and an end-to-side anastomosis is constructed with a running suture 5-0. The total period of clamping lasts between 10 and 15 minutes. Recovery of the portal flow is evidenced by normalization of the colour of the intestines and the aspect of the spleen and pancreas.

After careful hemostasis the intestines and the greater omentum are carefully repositioned in the abdominal cavity. The tips of the balloon occluders are anchored in a subcutaneous pocket. The abdomen is closed by a running suture, the skin in an interrupted way.

\section{Second stage.}

After 7-9 days the second stage was carried out. No premedication was given. After administration of $500 \mathrm{mg}$ ampicillin i.m., anesthesia was introduced with sodium pentobarbital $(10 \mathrm{mg} / \mathrm{kg})$ and followed by intubation and connection to the ventilator (Seneca ${ }^{R}$ in conjunction with a Pulmonat $19.1^{\mathbb{R}}$, Dräger Nederland B.V.).

Anesthesia was maintained only with intermittant fentanyl $i . v$. and oxygen. The dogs were positioned on an operating table on a warm water blanket. An angiocath (Braunule ${ }^{\mathrm{R}}$ ) was inserted percutaneously into a foreleg vein. The femoral artery and vein were catheterized with silastic catheters with the tips placed respectively in the iliac artery and peripherally. Three-way systems were connected for monitoring and for arterial and venous blood sampling. The attachments of the balloon occluders in the subcutaneous pocket were exposed. Regular monitoring was performed by measuring the following parameters:

* Blood pressure (Schwarzer type DME 47, with a CP-01 Transducer, Century Technology Cy., Inglewood, Calif.); 
* Pulse rate;

* Expiratory carbon dioxide $\left(\mathrm{CO}_{2}\right)$ concentrations (Capnolog ${ }^{\mathrm{R}}$ and Optocap ${ }^{R}$-sensor, Drägerwerk $A G$, Lübeck, Germany), either by continuously tracing changes in $\mathrm{CO}_{2}$-concentrations or by measuring the peak $\mathrm{CO}_{2}$ value. Ventilation was adjusted to maintain an end tidal carbon dioxide concentration of $4.5-5.0 \%$;

* Body temperature.

After positioning of the catheters, a $90 \mathrm{~min}$ stabilization period was allowed. Then, the common hepatic artery was occluded by inflating both balloon cuffs $(t=0)$. Reperfusion was allowed after 90 to 120 minutes. Arterial and venous samples were taken at $t=-60,-30,0,10,20,40,60,90$, 120,180 and 240 minutes. After 240 minutes the femoral arterial and venous catheters were withdrawn. The attachments of the balloon occluders were again placed in the subcutaneous pocket which was closed with some interrupted sutures.

After extubation the dogs were transferred to their cages. During the first hours in their cages $500 \mathrm{ml}$ saline $0.9 \%$ was infused, after which the catheter in the foreleg vein was removed. Arterial and venous sampling at $\mathrm{t}=420$ and $\mathrm{t}=720$ minutes was collected from the contralateral femoral artery and foreleg vein. When the dogs were awake, they were allowed to drink water. Dogs unable to drink received saline $0.9 \%$ subcutaneously.

\subsection{Liver biopsies}

Liver specimens were taken in control dogs, while in the ischemic group within 24 hours both in survivors and non-survivors biopsies were taken (Tru-cut ${ }^{\mathrm{R}}$-needle, Travenol). Survivors were biopsied 2, 4 and 6 weeks after acute hepatic ischemia. The specimens were fixed in 10 per cent neutral buffered formalin and processed into Paraplast ${ }^{\mathrm{R}}$. Routine histology was performed on $5 \mu \mathrm{m}$ sections stained with $\mathrm{H} / \mathrm{E}$ (hematoxilyn/eosine).

\subsection{Analytical methods}

Blood was collected in heparinized tubes and cooled on ice immediately. From the freshly drawn blood, $0.6 \mathrm{ml}$ was pipetted into a cooled test tube containing $60 \mu \mathrm{l}$ of the protease inhibitor aprotinin (Trasylol ${ }^{\mathrm{R}}$ ) for determination of Immunoreactive Glucagon (IRG). Tubes were centrifuged for 15 minutes at $2000 \mathrm{~g}$ at $4^{\circ} \mathrm{C}$. Plasma was removed and immediately stored at $-70^{\circ} \mathrm{C}$ until analysis.

Plasma ghcose was determined enzymatically with glucose-oxidase in a Beckman-glucose analyser-2. 
Plasma Immunoreactive Insulin (IRI) was determined with a commercially available radioimmunoassay kit (Wellcome, Beckenham, England) with human standards and antisera.

Plasma IRG was measured with a commercial radioimmunoassay kit (Biolab, Brussels, Belgium) with human standards and antisera.

Plasma amino acids were determined on a LKB Biochrom 4400 amino acid analyser running a physiological program with $5 \mathrm{Li}^{+}$-buffers as described by Dilley and Rocek (1979). The plasma was deproteinized with sulfosalicylic acid $(5 \% \mathrm{w} / \mathrm{v})$ and filtered through filters with $0.22 \mu \mathrm{m}$ pores (Millipore filters).

Plasma ammonia was determined enzymatically according to Da FonsecaWollheim (1974).

Plasma D-(-)-3-Hydroxybutyrate was determined enzymatically according to Williamson and Mellanby (1974).

Plasma acetoacetate was determined enzymatically according to Mellanby and Williamson (1974).

Plasma pyruvate was determined enzymatically according to Czok and Lamprecht (1974).

Plasma lactate was determined enzymatically according to Racine (1975).

Plasma free fatty acids were determined according to a colorimetric micromethod described by Duncombe (1964).

Plasma ALT (alanine aminotransferase) was determined with a commercially available test kit (Boehringer) based on the reaction conditions of Bergmeijer (1974).

Plasma AST (aspartate aminotransferase) was determined enzymatically with a commercially available test kit (Boehringer) based on the reaction conditions of Karmen (1955).

Mitochondrial AST (mAST) was separated from cytoplasmic AST (cAST) by column chromatography as described by Sampson (1978). Minicolumns with a total volume of $10 \mathrm{ml}$ were filled with ion-exchanger (DEAE-A5O Sephadex) and equilibrated overnight in $0.05 \mathrm{M}$ Tris- $\mathrm{HC} \|$ buffer, $\mathrm{pH}=$ 8.5 , containing $0.05 \mathrm{M} \mathrm{NaCl}$. The same buffer is used for elution of 1 $\mathrm{ml}$ of plasma containing the mixture of MAST and cAST. This procedure leaves CAST on the column while mAST is collected in the effluent. In a second elution step, with buffer containing $0.2 \mathrm{M} \mathrm{NaCl}, \mathrm{mAST}$ is also eluted from the column.

Plasma GLDH (glutamate dehydrogenase) was determined enzymatically with a commercially available test kit (Boehringer) according to the recommendations of the Deutsche Gesellschaft für Klinische Chemie (1970). Plasma CK (creatine kinase) was determined enzymatically with a commercially available test kit (Merck) according to the recommendations of 
the Deutsche Gesellschaft für Klinische Chemie (1977).

Plasma Catecholamines (epinephrine and norepinephrine) were determined by a radio-enzymatic catechol-0-methyl transferase method (COMT) (Engel, 1983).

\subsection{Quantitation of liver injury}

Cumulative release of enzyme per litre of plasma, $Q(t)$, was calculated from plasma enzyme activities in patients, and for ALT in the dog, according to the equation (Willems, 1982):

$$
\mathrm{Q}(\mathrm{t})=\overline{\mathrm{C}}(\mathrm{t})+\mathrm{E}(\mathrm{t})+\mathrm{FCR} \cdot \int_{0}^{1} \overline{\mathrm{C}}(\tau) \mathrm{d} \tau
$$

This equation is based on the two-compartment model as shown in fig. $3.7-1$. The validity of this model for the quantitative description of circulating proteins was discussed by Hermens (1982). An essential feature of this model, direct input of enzymes in plasma, is well-established for enzyme release from the heart as well as from the liver. The three terms in equation (1) represent respectively the enzyme activity present in plasma at time $t(\overline{\mathrm{C}}(\mathrm{t}))$, the extravascular enzyme activity at time $\mathrm{t}(\mathrm{E}(\mathrm{t}))$ and the enzyme activity that has been eliminated from plasma up to time $t$ (FCR: fractional catabolic rate constant). The extravascular enzyme activity is calculated from this equation:

$$
E(t)=T E R \cdot \exp (-E R R \cdot t) \int_{0}^{1} \exp (E R R \cdot \tau) \bar{C}(\tau) d \tau
$$

where TER and ERR are respectively the transcapillary escape rate constant and the extravascular return rate constant. Parameter values used in equations (1) and (2) for patients were: $F C R_{C K}=0.20 \mathrm{~h}^{-1}, F_{C R} R_{H B D}=$ $0.015 \mathrm{~h}^{-1}, \mathrm{FCR}_{\mathrm{ALT}}=0.042 \mathrm{~h}^{-1}, \mathrm{TER}=0.014 \mathrm{~h}^{-1}, \mathrm{ERR}=0.018 \mathrm{~h}_{-1}, \mathrm{C}_{\mathrm{s}}$ $(\mathrm{CK})=47 \mathrm{U}$ litre $^{-1}, \mathrm{C}_{\mathrm{s}}(\mathrm{HBD})=80 \mathrm{U}^{\mathrm{litre}}{ }^{-1}$ and $\mathrm{C}_{s}(\mathrm{ALT})=7 \mathrm{U} \mathrm{litre}^{-1}$ $\left(C_{s}:\right.$ steady state plasma activity). Parameter values used in dogs were:
TER $=0.031 \mathrm{~h}^{-1}, E R R=0.069 \mathrm{~h}^{-1}$ and $\mathrm{FCR}_{\mathrm{ALT}}=0.022 \mathrm{~h}^{-1}$. 


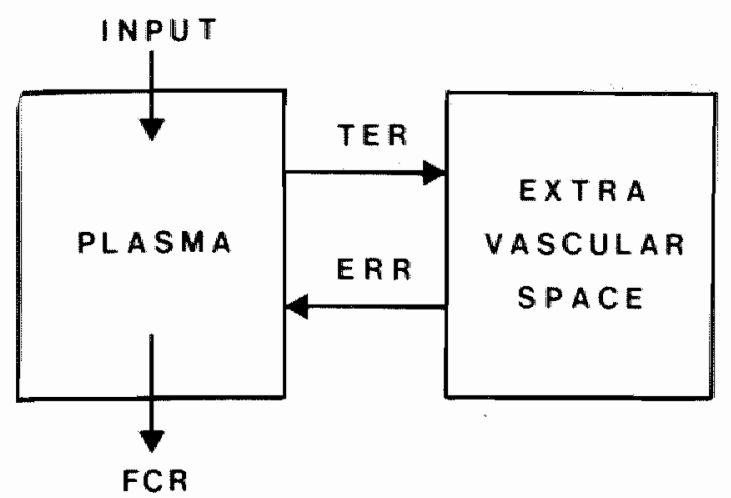

Figure 3.7-1: Two-compartment model for circulating proteins.

FCR : Fractional catabolic rate;

TER : Tramscapillary escape rate;

ERR : Extravascular return rate.

\subsection{Statistics}

The data from experiments employing two groups were statistically evaluated using Student's $t$ test for paired observations. Results obtained are given as the mean \pm standard error of the mean. 



\section{Arterial hepatic blood flow after a portacaval shunt and devascularization of the liver}

\subsection{Introduction}

The effect of surgery and anesthesia on hepatic blood flow has been repeatedly investigated. Over the years hepatic blood flow measurement techniques have ranged from crude estimates such as blood lost from severed hepatic vessels during a certain period, to the more sophisticated laser Doppler velocimetry or hydrogen clearance techniques. All currently available techniques have important limitations. Several necessary assumptions such as the liver's specificity for the clearance of certain dyes, the presence or absence of extrahepatic shunts, and the preservation of normal hepatic function during invasive monitoring have been shown to be unsound (Bradley, 1974; Gelman, 1976; Teranaka, 1977; Leiberman, 1978; Nxumalo, 1978; Richardson, 1981; Corbic, 1984; Vorobioff, 1984 and Gouma, 1986). An ideal method to measure hepatic blood flow, takes into account not only intrahepatic shunting, but also spontaneous and surgically induced extrahepatic portalsystemic shunting, so that a volumetric estimation of total hepatic blood flow results. The microsphere technique employs an absolute arterial volume flow reflecting a true state of tissue perfusion, i.e. the rate of blood flow per unit of liver perfused.

\subsection{Measurement of arterial blood flow in the liver}

Regional arterial blood flow was determined by the microsphere method described by Prinzen (1981) and van der Veen (1985). In this study microspheres with a diameter of $15 \mu \mathrm{m}$ and labeled with $\mathrm{Ce}^{141}$ (Cerium), $\mathrm{Sn}^{113}$ (Stannium), $\mathrm{Ru}^{103}$ (Ruthenium) and $\mathrm{Nb}^{95}$ (Niobium) were used (New England Nuclear, Boston, U.S.A.). Several authors demonstrated that after injection of these spheres radioactivity measured in different organs is proportional to the percentage of the cardiac output received by the organ. Microspheres were delivered in injection vials suspended in $10 \%$ Dextran with $0.05 \%$ Tween 80 as surfactant to reduce aggregation of the microspheres. As described by van der Veen (1985) each batch was checked 
for:
a. purity of the nuclide
b. specific activity of the microspheres,
c. integrity of the microspheres,
d. leakage of the nuclides and
e. diameter distribution of the beads.

Each batch was controlled for the number of microspheres per gram as indicated by the manufacturer. Total activity (mCi) and specific activity ( $\mathrm{mCi} / \mathrm{gm}$ ) were also determined. The required number of microspheres from our stock solution was diluted wice in $10 \%$ Dextran in a $5 \mathrm{ml}$ syringe. After thoroughly shaking on a Vortex agitator the syringe was put in an ultrasonic bath. Sonification should be performed to prevent sedimentation of the beads. Shortly before injection the syringe was again shaken on the Vortex for $1 \mathrm{~min}$, and subsequently the microspheres were injected.

In six dogs, excluded from the merabolic and enzymatic studies, an endto-side portacaval shunt with a devascularization procedure of the liver except the hepatic artery was performed. In four dogs the retrograde flow was interrupted, that means ligation of the gastroduodenal artery and, if necessary, the right gastric artery (see chapter 3.4). The two remaining dogs underwent the same procedure, but ligation of the gastroduodenal and right gastric artery was omitted in order to measure retrograde flow. Directly after these operative procedures microspheres were injected into the thoracic aorta via a catheter inserted in a common iliac artery. An arterial reference sample was taken from the contralateral common iliac artery at a rate of $20.7 \mathrm{ml} / \mathrm{min}$, using a Harvard withdrawal pump. A second microsphere isotope was injected after occlusion of the common hepatic artery and again arterial reference blood samples were collected. After one week the two dogs with intact retrograde flow, had repeated injections with two microsphere isotopes, different from those initially used, again without and with a clamped common hepatic artery.

After the experiment the liver was excised, freed from adjacent structures (vessels, ligaments, gallbladder) and stored at $-70^{\circ} \mathrm{C}$. The hepatic lobes were dissected free and each lobe was sliced into pieces of approximately 3 gram. These tissue pieces were put into test tubes and overall liver blood flow and the flow in each lobe was calculated from the weight and the Tow in each piece. All tissue samples were put into $10 \mathrm{ml}$ PVC test tubes. These tubes were weighed empty and with the sample. The weighing results were entered into a data-entry system. The arterial blood samples and the pieces of liver tissue were counted in a Packard Multi-Channel Analyzer and arterial flow was calculated according to the MIC II program input (Van der Veen, 1985). 


\subsection{Results}

In $\operatorname{dog} 1,2,3$ and 4 , directly after performing an end-to-side portacaval anastomosis with a devascularization procedure of the liver and with interrupted retrograde flow, the common hepatic arterial blood flow amounted to $29,19,27$ and $74 \mathrm{ml} / \mathrm{min} / 100 \mathrm{~g}$ of liver tissue respectively (table 4-1). By occluding the common hepatic artery the flow was in three dogs less than $1 \%$. After the procedure only a minimal flow was still measured in $\operatorname{dog} 2$, about $7 \%$ of the original flow. These findings provide evidence for the completeness of the devascularization procedures. Dog 5 and 6 , with a portacaval shunt and the devascularization procedure of the liver, but without ligation of the gastroduodenal artery and/or the right gastric artery, demonstrated support for the remarkable amount of retrograde flow through these arteries, 10 and $16 \mathrm{ml} / \mathrm{min} / 100 \mathrm{~g}$ of liver tissue respectively (table 4-1). These findings were in agreement with the anatomical relationship of the extrahepatic arterial blood supply as described in chapter 2 . One week later in these dogs no significant change of the flow in the common hepatic artery was measured, 36 versus 45 and 39 versus $37 \mathrm{ml} / \mathrm{min} / 100 \mathrm{~g}$, respectively (table $4-2$ ). The retrograde flow still existed, but was only 3 and $4 \mathrm{ml} / \mathrm{min} / 100 \mathrm{~g}$ comprising $8 \%$ and $10 \%$ of the flow in the common hepatic artery. After one week the percentage of the retrograde flow had dropped to 25 and 30 per cent of the original retrograde flow. In tables 4-1 and 4-2 the amount of flow in the four lobes of the liver is listed. As far as could be ascertained, the literature does not mention amounts of flow in the different lobes. Some differences between the lobes can be seen, but overall no preferential flow exists.

\section{4,4. Discussion}

Hemodynamic studies of portalsystemic shunting in experimental animals have dealt with changes in hepatic arterial and portal venous blood flow immediately after shunting. It was generally accepted that hepatic arterial blood flow rises in response to portasystemic shunting (Thiel, 1980). However, the initial assumption that this response was permanent has not been confirmed (Richardson, 1981; Shatney, 1982a). In experiments designed to quantify the long-term effects of canine portalsystemic shunting on hepatic blood flow, Shatney (1982a) observed changes in portal and non-hepatic visceral blood flow. As a result of these alterations in nonhepatic arterial visceral perfusion, there was a remarkably consistent increase in portal venous blood flow 3 weeks after portalsystemic shunting, 


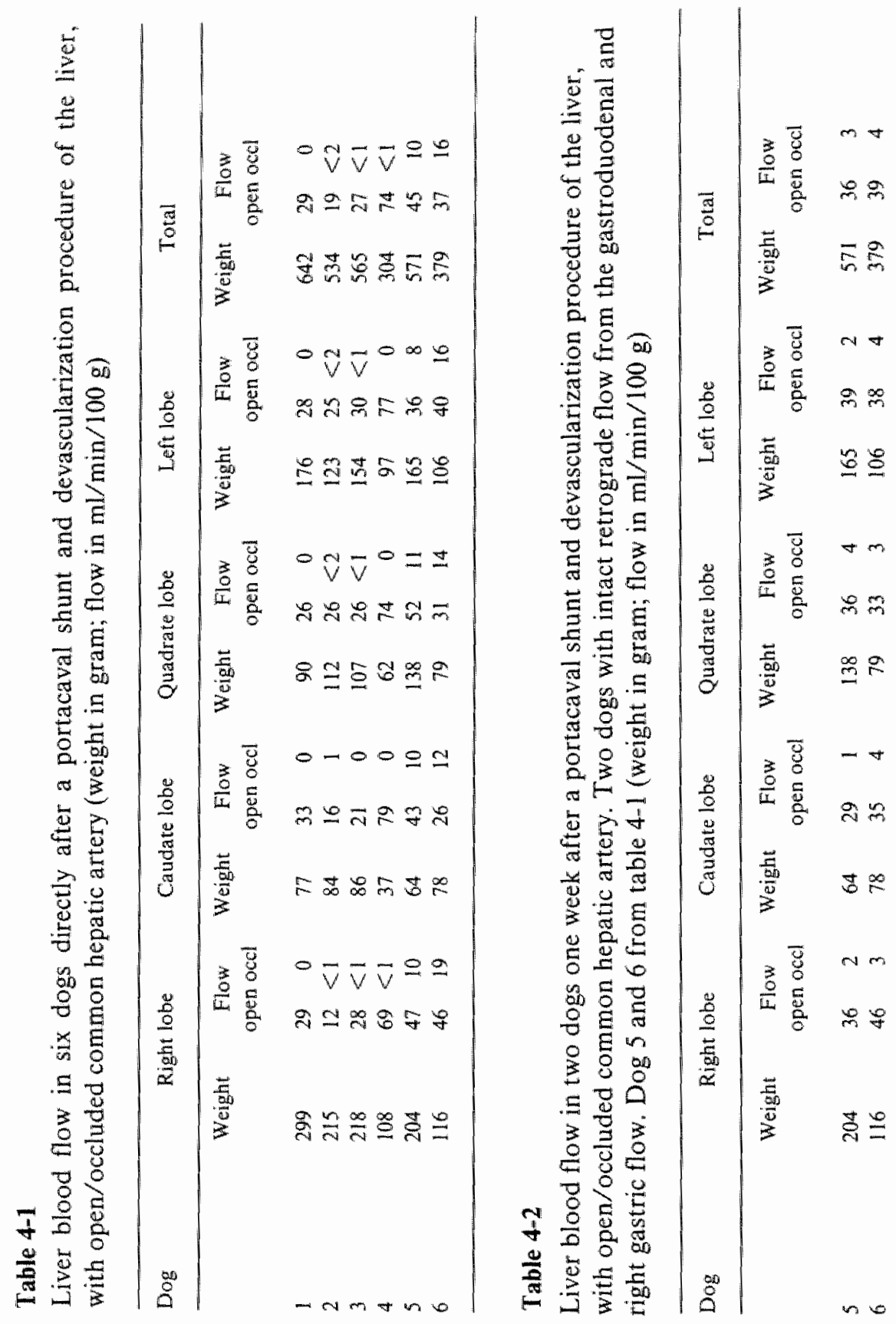


especially in dogs with an end-to-side portacaval shunt. Shatney concluded that there is a significant permanent reduction in total hepatic blood flow in all animals after an end-to-side portacaval shunt. The mean hepatic arterial blood flow stabilizes just below the baseline level, after a transient and small increase directly after the surgical procedure. Gurll (1980) measured the splanchnic regional blood flow by the microsphere technique before and after end-to-side portacaval shunt in dogs. An immediate increase in hepatic arterial blood flow was demonstrated, returning to control values three weeks later. On the other hand there was a significant increase in pancreatic, duodenal and jejunal blood flow. In contrast to Shatney (1982b), Gurll failed to detect an early increase in portal venous flow after the portacaval shunt. As described in chapter 2 several authors investigated the remarkable collateral arterial blood flow to the liver. However, both the amount of retrograde flow as well as the flow from the gastrohepatic ligament and the hepatic branches of the phrenic arteries, were often neglected in clamping studies in combination with a portalsystemic shunt. The striking retrograde flow that we demonstrated is only confirmed by Yokota (1979). In portacaval shunted dogs the common hepatic artery was clamped, but a total devascularization procedure of the liver was omitted. Thus, total hepatic blood flow demonstrated by angiography, consisted of the retrograde flow in addition to the flow of the hepatic branches of the phrenic arteries and the arteries in the gastrohepatic ligament. Most studies focus on flow especially in the common hepatic artery and/or the portal vein and changes in flow in these vessels in several pathophysiological conditions, but overlook the remarkable amount of flow from other arteries (Hollenberg, 1966; Crook, 1970; Leiberman, 1978).

Popper (1954) has discussed the capacity of the liver to adjust to a minimal arterial blood flow, that can still provide sufficient oxygen for adequate function. Green way (1971) and Lindberg (1981) stressed the wide variation in the amount of the total liver blood flow supplied by the hepatic artery. In a review Lautt (1977) concluded that it is clear that the metabolic activity of the liver does not control hepatic arterial resistance, but that the factors that control hepatic arterial flow under normal situations are still unknown. From these data we conclude that in literature the anatomical variability of the extrahepatic arterial blood supply has largely been neglected. Especially in clamping studies of the common hepatic artery, with or without a portalsystemic shunt, the existence and the amount of retrograde flow was neglected.

Our data clearly demonstrate that this retrograde flow may be considerable. This may explain preservation of liver function after clamping 
studies in which the blood flow is erroneously considered to be totally occluded, because retrograde and collateral flow are not taken into account. 


\section{Metabolic parameters in acute liver ischemia in dogs}

\subsection{Introduction}

It is the purpose of this study to establish and characterize a reproducible model of acute liver damage and liver insufficiency. The portacaval shunt model has been well defined metabolically (Aguirre, 1974; Fischer, 1976; Soeters, 1977 and 1979 and Oostenbroek, 1982) but deprivation of portal blood to the liver does not cause liver damage and liver insufficiency in the acute experiment. On the contrary, the portacaval shunt may lead in dogs to liver insufficiency only after 6 weeks or longer periods. In younger dogs, when housed under optimal conditions, hepatic insuffiency may never ensue. Therefore in this study, in addition to a portacaval shunt, the arterial blood supply was thoroughly clamped to achieve liver ischemia. In our efforts to establish a reproducible dog model to study acute liver ischemia we were primarily interested to define the sequential metabolic characteristics occurring after occlusion of the arterial blood supply in the presence of a portacaval shunt, and to define metabolic parameters, that may indicate at an early stage the severity of the ischemic insult and simultaneously predict survival.

For this purpose in this chapter aspects of glucose-, fat- and amino acid metabolism were studied in conjunction with pancreatic hormones and catecholamines. Special attention was payed to those parameters that have been claimed, separately or in combination, to indicate the severity of liver impairment.

In anumal models of acute liver ischemia hypoglycemia has been consistently described. Fluctuations in blood glucose levels are prevented by the effects of glucagon. Impending hypoglycemia requires an immediate hepatic delivery of glucose, a process that is, at least to a large part, glucagonmediated. During acute liver ischemia hepatic glycogenolysis and gluconeogenesis may be expected to be seriously impaired leading to hypoglycemia and consequently to adaptational hyperglucagonemia. The extent. of hypoglycemia and the resulting hyperglucagonism may therefore reflect liver impairment. Unger (197la and b) has stated that the glycogenolytic, 
gluconeogenetic and lipolytic effects of glucagon are precisely the opposite of those of insulin. Insulin and glucagon exert therefore a bihormonal control of the balance of transhepatic glucose levels. Therefore not only the isolated actions of these hormones should be considered but also their combined action.

In addition, however, these hormones also regulate the disposition of gluconeogenic amino acids in the liver. The ischemic insult to the liver most likely induces net catabolism. The (gluconeogenic) amino acids glutamine and alanine and the essential amino acids except the branched chain amino acids resulting from this net catabolism largely rely for their degradation on the splanchnic tissues. Increments in plasma of these amino acids may therefore reflect the severity of liver impairment. The branched chain amino acids are largely degraded peripherally (Soeters, 1983). The ratio between the branched chain amino acids and the aromatic amino acids has therefore been claimed to be a measure for liver failure and especially encephalopathy (Fischer, 1976). Therefore the amino acids mentioned will be evaluated, separately and as a ratio, as potential indicators of liver damage and the eventual outcome. Recently Clowes (1984 and 1985) has advocated the use of a central plasma clearance rate of amino acids (AA) as a potentially useful indicator of the ability of the organism c.q. liver to invoke an effective response to injury. To measure the central clearance of AA a clearance rate was determined consisting of the arterialvenous $(A-V)$ difference of total $A A$ over the leg divided by the arterial AA levels. $A$ better term for clearance rate $(A-V / A)$ would be 'extraction rate'. Because of its use in the literature, however, we will continue using the term clearance rate. To calculate central clearance the clearance rate was multiplied by a factor determined by the assumed leg flow. Leg flow was estimated to comprise $5 \%$ of cardiac output. Central clearance can only be calculated, however, when a steady state exists, namely AA concentrations should not change indicating that all AA released are indeed cleared by the splanchnic tissues. Furthermore cardiac output should be measured and should remain constant including the part of cardiac output that flows to the leg. Clowes' data suggest that survival coincides with high central clearances whereas low clearances coincide with increased mortality. Because two of the required assumptions can not be met in our dog model we can not calculate total central clearance but will only study the significance of clearance rate (A-V/A) as a potential early indicator of mortality.

Over the decades ammonia has been used as a parameter for liver failure. 
In clinical practice the arterial plasma ammonia level may still serve as a useful indicator of chronic hepatic encephalopathy. In acute liver failure however this is questionable, because ammonia levels are not always increased in acute hepatic failure, and because they do not correlate with the degree of encephalopathy. In addition to plasma amino acid levels plasma ammonia levels will be included in the evaluation of its predictive value with regard to acutely induced liver damage and outcome.

Finally Japanese workers (Ukikusa, 1981 and Ozawa, 1983) have suggested that the arterial ketone body ratio (acetoacetate and betahydroxybutyrate) may reflect the redox potential which in turn may parallel the energy charge of the liver. A depression of the ketone body ratio could therefore reflect severe liver damage.

The aforementioned aspects of metabolism will be characterized and evaluated with regard to their possible ability to reflect the seriousness of the insult to the liver with regard to survival or non-survival.

\subsection{Material and methods}

The experimental dog model has been outlined in chapter 3. Also the analytical techniques employed are described in that chapter.

In 7 dogs the hepatic artery was occluded for 60 minutes. Six of the 7 dogs survived.

In the definitive study employing $12 \mathrm{dogs}$, an occlusion time of 90 to 120 minutes was therefore instituted. In control dogs the whole procedure was carried out except for the occlusion of the hepatic artery. Arterial and venous blood samples were obtained before initiation of ischemia during a 90 minutes equilibration period and afterwards as indicated in chapter 3 and in the results section of this chapter. The dogs that were subjected to occlusion had undergone a portacaval shunt one week earlier. Evaluation of pre-occlusion values of the parameters of interest is even more important than normally, because tolerance to a portacaval shunt may differ between dogs. Occlusion of the hepatic artery and the control experiment were carried out under fentanyl anesthesia. Four hours after initiation of ischemia or of the control experiment anesthesia was terminated. Animals were carefully monitored for oxygenation and blood pressure. Resuscitation if necessary occurred only with $0.9 \%$ saline. Metabolic parameters were recorded and analyses performed as described earlier in chapter 3 . 


\subsection{Results}

Pilot study ( 60 minutes occlusion)

In table 5-1 plasma glucose, immunoreactive insulin (IRI) and immunoreactive glucagon (IRG) are demonstrated. Glucose levels did not decrease significantly. Plasma IRG levels however rose significantly at $t=20$ and $t=40 \mathrm{~min}$. Plasma IRI level did not rise significantly when compared to $t=-30$ min basal level. When the insulin levels at $t=0$ are considered ( 12 $\mu \mathrm{U} / \mathrm{ml}$ ) significant increases in plasma IRI occurred. Only one dog died during these experiments and was found to have a necrotic liver at autopsy. The elevations in plasma IRG persisted after deflation of the balloon occluders while normoglycemia was maintained. The marked increase in the standard error reflects the variability of the plasma IRG levels in different dogs. During this pilot study hypoglycemia was not encountered, and mortality was low. In the definitive experiment therefore longer occlusion times were employed.

\section{Table 5-1}

Arterial and venous values for glucose, immunoreactive insulin (IRI) and immunoreactive glucagon (JRG) in the pilot study $(n=7 ; 60$ minutes occlusion)

\begin{tabular}{lllllll}
\hline$x \pm S E$ & \multicolumn{2}{l}{ Glucose $(\mathrm{mmol} / \mathrm{l})$} & \multicolumn{2}{l}{ IRI $(\mu \mathrm{U} / \mathrm{ml})$} & \multicolumn{2}{l}{ IRG $(\mathrm{pg} / \mathrm{ml})$} \\
$\mathrm{t}$ in min & art. & ven. & art. & ven. & art. & ven. \\
\hline-60 & $5.8 \pm 0.2$ & $5.4 \pm 0.4$ & $15 \pm 2.4$ & $14 \pm 3.0$ & $328 \pm 39$ & $315 \pm 72$ \\
-30 & $5.8 \pm 0.2$ & $5.1 \pm 0.3$ & $20 \pm 3.4$ & $14 \pm 3.3$ & $426 \pm 67$ & $275 \pm 43$ \\
0 & $6.0 \pm 0.3$ & $5.2 \pm 0.4$ & $12 \pm 1.6$ & $13 \pm 1.5$ & $376 \pm 37$ & $300 \pm 59$ \\
10 & $6.0 \pm 0.3$ & $5.2 \pm 0.3$ & $15 \pm 1.2$ & $11 \pm 1.7$ & $463 \pm 63$ & $295 \pm 58$ \\
20 & $5.9 \pm 0.4$ & $5.2 \pm 0.3$ & $16 \pm 2.0$ & $13 \pm 1.0$ & $474 \pm 61$ & $343 \pm 50$ \\
40 & $6.0 \pm 0.4$ & $5.3 \pm 0.3$ & $16 \pm 1.8$ & $13 \pm 2.8$ & $519 \pm 66$ & $348 \pm 60$ \\
60 & $5.9 \pm 0.4$ & $5.4 \pm 0.3$ & $22 \pm 5.0$ & $16 \pm 2.4$ & $595 \pm 52$ & $410 \pm 83$ \\
90 & $5.9 \pm 0.3$ & $5.3 \pm 0.3$ & $16 \pm 6.0$ & $15 \pm 4.3$ & $733 \pm 105$ & $477 \pm 92$ \\
120 & $5.7 \pm 0.4$ & $5.2 \pm 0.3$ & $19 \pm 5.0$ & $14 \pm 4.0$ & $964 \pm 150$ & $610 \pm 149$ \\
180 & $5.4 \pm 0.2$ & $5.0 \pm 0.4$ & $16 \pm 3.0$ & $12 \pm 5.6$ & $919 \pm 155$ & $770 \pm 277$ \\
240 & $5.7 \pm 0.3$ & $5.0 \pm 0.4$ & $19 \pm 3.2$ & $11 \pm 2.7$ & $1100 \pm 325$ & $838 \pm 342$
\end{tabular}


Definitive experiment (120 minutes occlusion)

- Plasmaglucose, IRI and IRG.

Figures 5.3-1, 5.3-2 and 5.3-3 demonstrate plasma glucose, IRI and IRG of both surviving and non-surviving dogs. Arterial IRI levels were significantly increased at $t=-30$ in non-survivors in comparison with survivors. Most striking are progressive, continuous elevations of arterial and venous plasma IRG, significant at 40 minutes after occlusion. Plasma IRI exhibited a slight elevation after occlusion, which in contrast to the pilot study was significant at 10 and 20 minutes both for arterial and venous blood when compared with preocclusion levels and when compared with control dogs. Arteriovenous differences of IRI and IRG

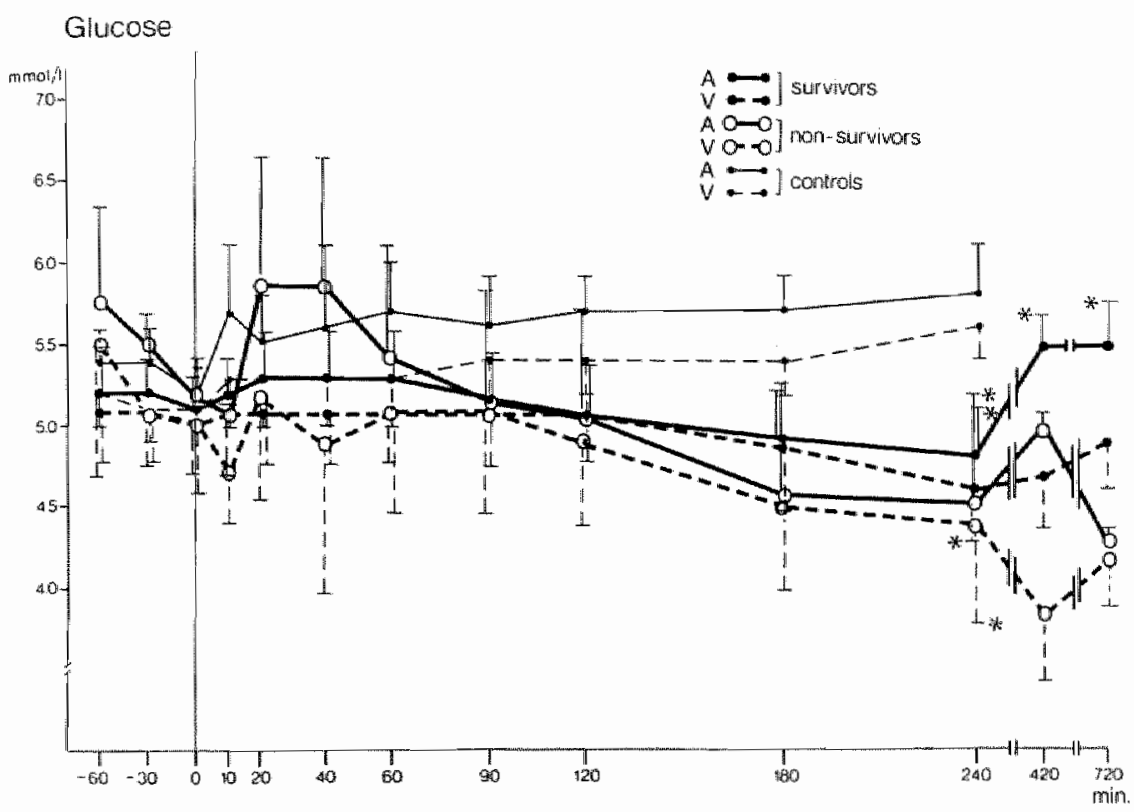

Fig. 5.3-1: Plasma arterial (A) and venous (V) glucose values ( $\mu$ mol/L; mean \pm SEM) in controls, survivors and non-surwivors.
$p<0.05$
C vs S
$t=240$
A and $\mathrm{V}$
S vs NS
$t=420,720$
A 
tended to be higher in occluded dogs than in controls. In the pillot study no significant changes or even trends in plasma glucose levels could be detected. During 120 minutes of occlusion plasma glucose levels tended to decrease after 60 minutes whereas significance was reached after 240 minutes. Plasma glucose, IRI and IRG all rose clearly after termination of anesthesia. Although arterial and venous IRI and IRG levels tended to be higher in non-survivors than in survivors, at almost all time points after occlusion significance was only reached at $t=120$ for IRI. Three out of 4 non-surviving dogs suffered greater decreases in plasma glucose levels than all but one of the surviving dogs. After discontinuation of anesthesia glucose levels rose in survivors, whereas levels stayed depressed in non-survivors (arterial glucose $p<0.05$ at $t=420$ and 720 ).

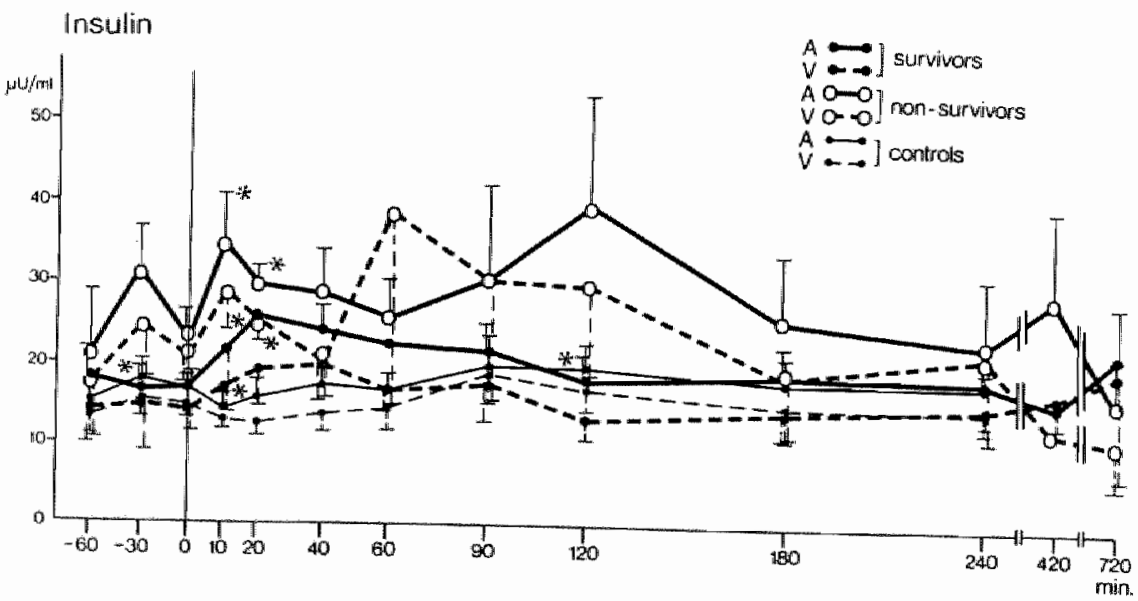
Fig. 5.3-2: Plasma arterial (A) and wenous (V) insulin values ( $\mu \mathrm{U} / \mathrm{ml}$; mean $\pm \mathrm{SEM})$ in
controls, surviwors and non-survivors.

$\begin{array}{llll}\mathrm{p}<0.05, & \text { C vs NS } & t=10,20 & \\ \text { Svs NS } & t=-30,120 & \text { A and V } \\ & & \text { A } \\ & & \text { V }\end{array}$




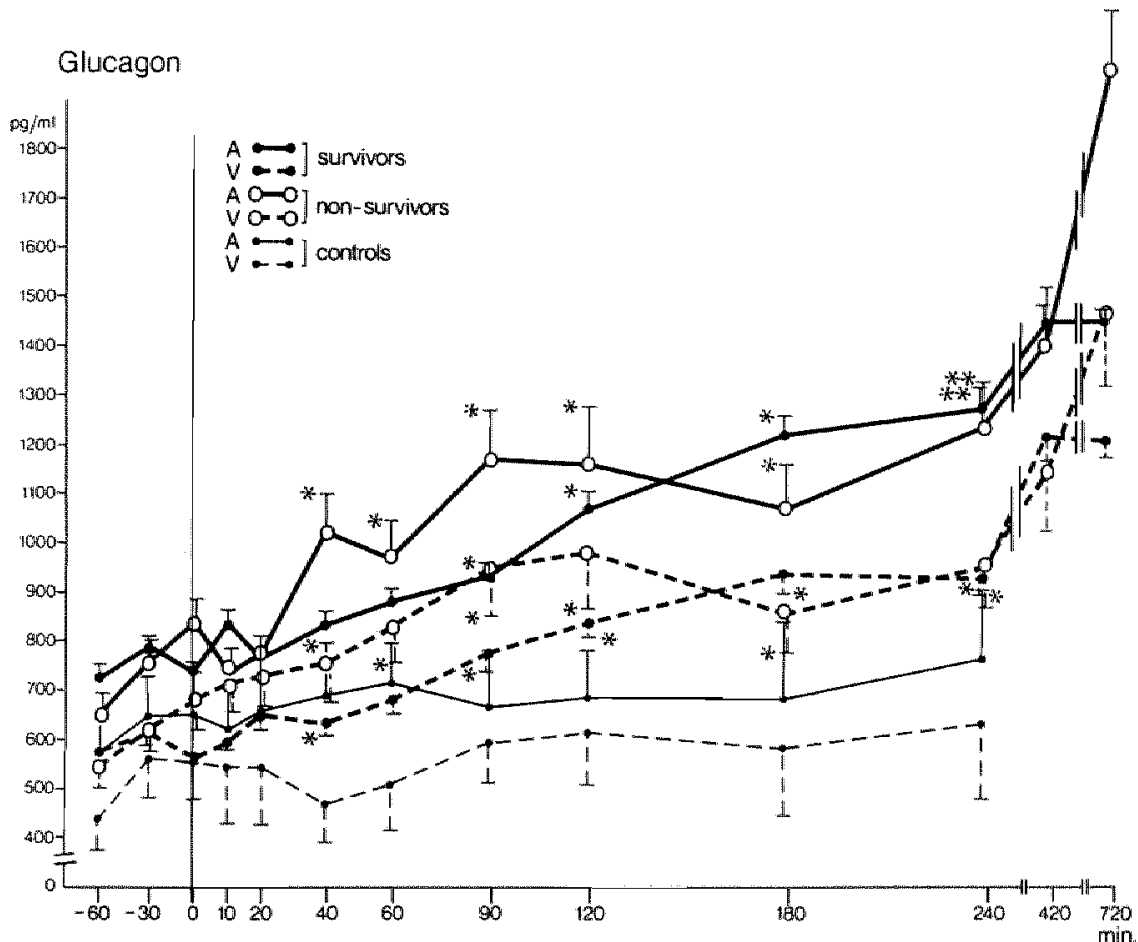

Fig. 5.3-3: Plasma arterial (A) and venous (V) glucagon values (pg/mi; mean \pm SEM) in controls, survivors and non-survivors.

$\begin{array}{llll}p<0.01, & C \text { vs } S & t=240 & A \\ p<0.01, & C \text { vs NS } & t=240 & \text { A } \\ p<0.05, & \text { C vs } S & t=40,60,240 & \text { V } \\ & & t=90,120,180 & \text { A and V } \\ p<0.05, & \text { C vs NS } & t=40,60,90,120,180 & \text { A and V } \\ p<0.05, & \text { C vs NS } & t=240 & \text { V }\end{array}$


- Epinephrine and norepinephrine.

Because of the costs involved in the analysis of plasma catecholamine: measurements were limited to arterial samples in dogs that underwen occlusion of the hepatic artery. The choice of fentanyl-oxygen anesthesi appears to be appropriate because the mean initial values of especiall epinephrine did not fluctuate considerably and were low after inductios of anesthesia and before induction of ischemia (fig. 5.3-4 and fig. 5.3 5). Norepinephrine levels tended to be increased at $t=-30$ and $t=0$ in the non-surviving dogs compared to the survivors, whereas only minol

Epinephrine

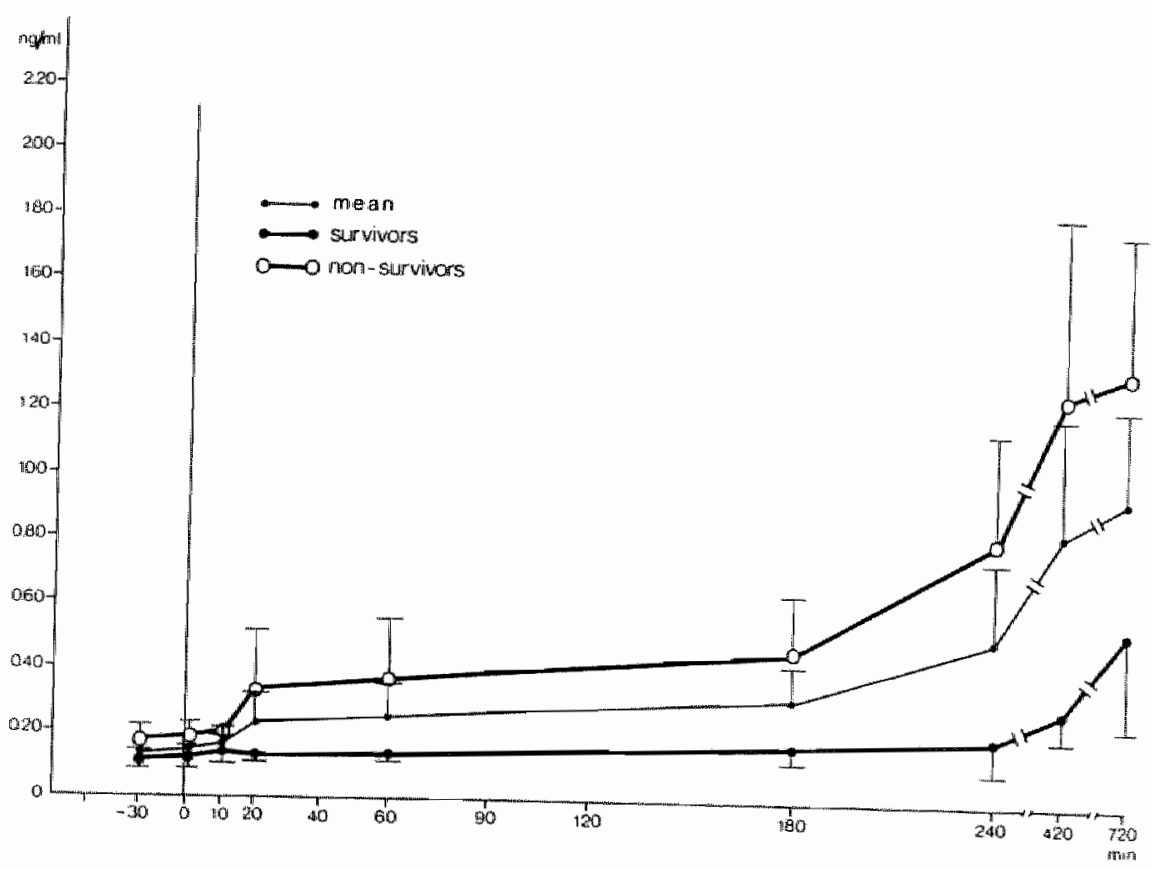

Fig. 5.3-4: Plasma arterial values ( $\mathrm{ng} / \mathrm{ml}$; mean \pm SEM) of epinephrine in survivors and non-survivors, with the mean vallue of the whole group. 
differences were noted in epinephrine levels at these time points. After induction of ischemia both epinephrine and norepinephrine rose slightly in the group as a whole, not significantly however. This is mainly due to the clear increase in the non-surviving dogs. At $t=420$ and $t=720$, when the dogs have woken up and are back in their cages, increases in all dogs are accentuated, which may largely be due to postoperative pain and stress. After occlusion norepinephrine and epinephrine levels were elevated in the non-survivors at all timepoints, compared to the survivors. Differences were not significant however and the large standard deviation precludes the use of epinephrine levels as an early indicator of survival in the individual dog.

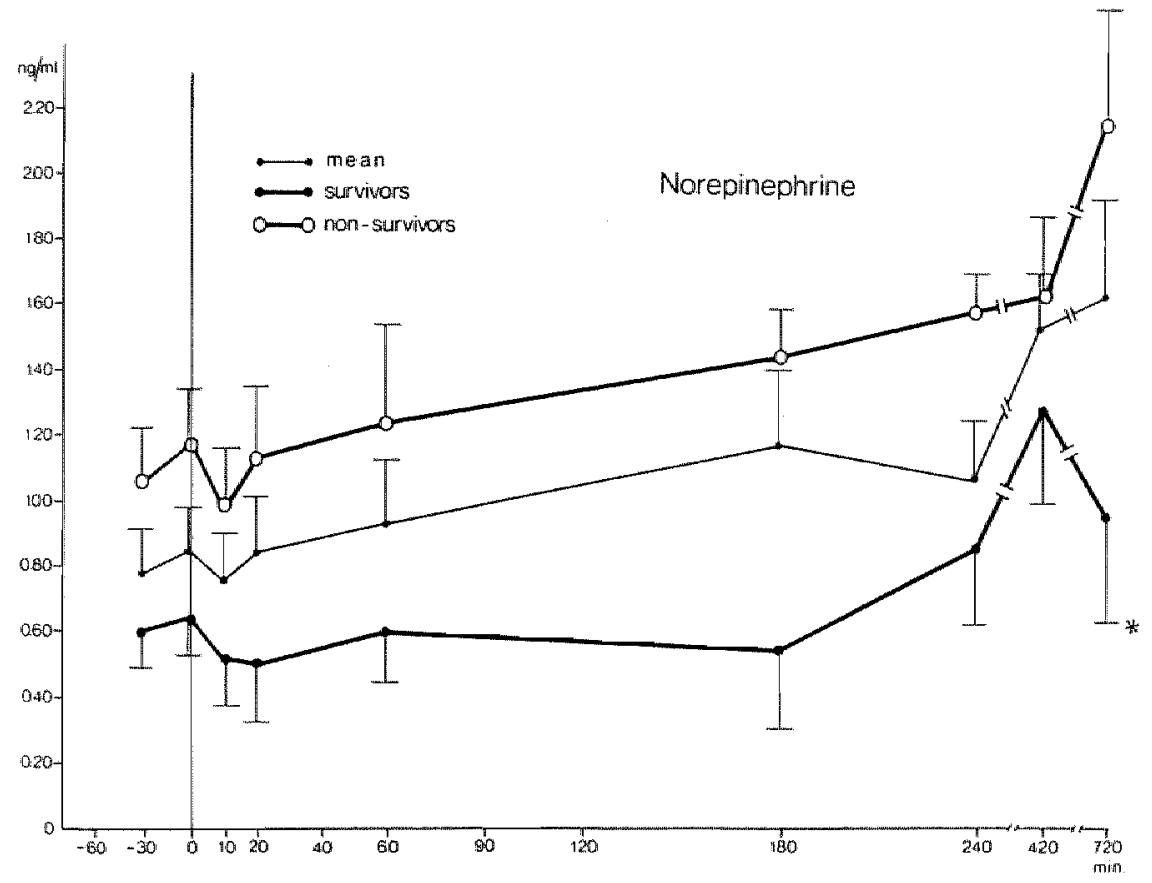

Fig. 5.3-5: Plasma arterial values (ng/ml; mean \pm SEM) of norepinephrine in survivors and non-survivors, with the mean value of the whole group.

$p<0.05 \quad S$ ws NS $\quad t=720$ 
- Amino acids.

The main amino acids present in plasma have been divided into fiv groups: alanine (Ala), glutamine (GIn), branched chain amino acid (BCAA), aromatic amino acids (AAA) and the other amino acids (AA) notably threonine, serine, asparagine, glycine, methionine, lysine, his tidine, citrulline, arginine and ornithine.

In the controls, the arterial-femoral venous differences (A-fV) for the AAA and the BCAA were negligible (fig. 5.3-6 and 5.3-7). At $t=C$ and $t=60$, a net uptake of $A A A$ and $B C A A$ or a zero balance appeared to exist. At $t=120$ and $t=240$ a net release, albeit small, of $B C A A$ and AAA was measured over the hindleg. Alanine also exhibited a small uptake at $t=0$ and $t=60$, wereafter a small release occurred (fig. 5.3-8). Glutamine was released at all time points (fig. 5.3-9).

In the occluded group a net release of BCAA and AAA already occurred at $t=0$, which is difficult to explain. After occlusion an immediate slight but progressive increase in the release of AAA occurred which became significant at $t=180$. Coinciding with this release arterial levels slowly increased, so that net release of AAA over the hindleg rose only slightly. BCAA behaved differently. Similar to the AAA already at $t=0$ a clear net release of $B C A A$ was noted. At $t=60$ release increased which became significant at $t=180$. Arterial levels however remained stable until $t=120$ whereafter they increased.

Compared to the control group net release of AAA and BCAA was greatly increased in the occluded group (fig. 5.3-6 and fig. 5.3-7). Net release of BCAA and glutamine showed a tendency to be increased in non-survivors at $t=0$, possibly also before occlusion, resulting in a BCAA/AAA-ratio which tended to be lower in the non-surviving group. The arterial (as well as the venous) BCAA/AAA-ratio rose slightly from $t=0$ to $t=240$ in the surviving dogs. Only a very minimal decrease of this ratio could be measured at $t=420$ and $t=720$ in the non-surviving dogs (fig. 5.3-10).

The arterial and venous levels of alanine and glutamine showed a tendency to rise immediately after occlusion at $t=20$ and $t=60$ both in survivors and non-survivors (fig. 5.3-8 and 5.3-9). Thereafter levels remained stable in survivors whereas levels tended to rise further in non-survivors. Also for these amino acids remarkable A-fV differences were demonstrated. Net release of alanine and glutamine was most marked at $t=120$. In the suvivors net release was low at $t=0$, and increased thereafter. Net release stayed elevated also after termination of the occlusion. In the non-survivors release was high already at $t=0$ and
thereafter declined. 


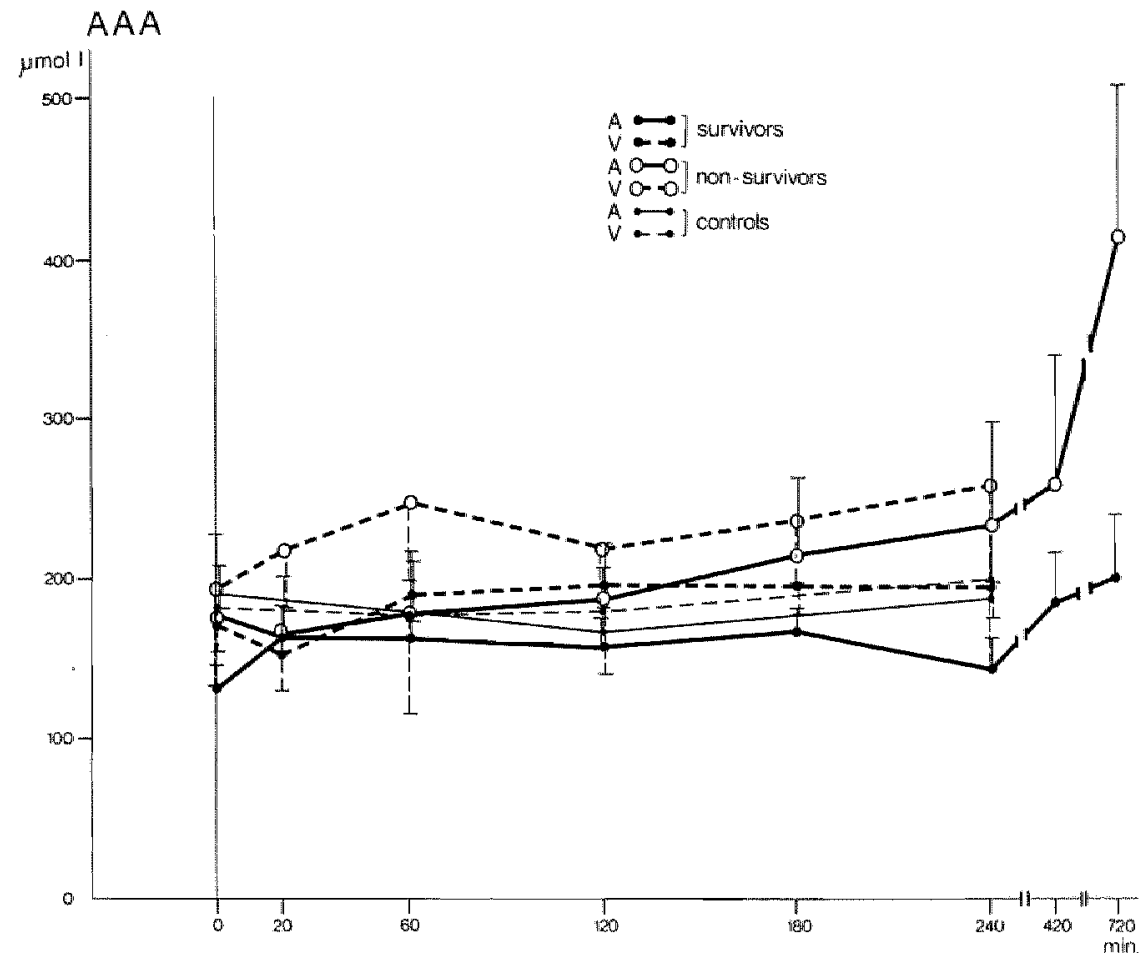

Fig. 5.3-6: Pllasma arterial (A) and venous (V) walues ( $\mu$ mol/L; mean $\pm S E M$ ) of aromatic amino acids (AAA) in controls, survivors and non-survivors. 


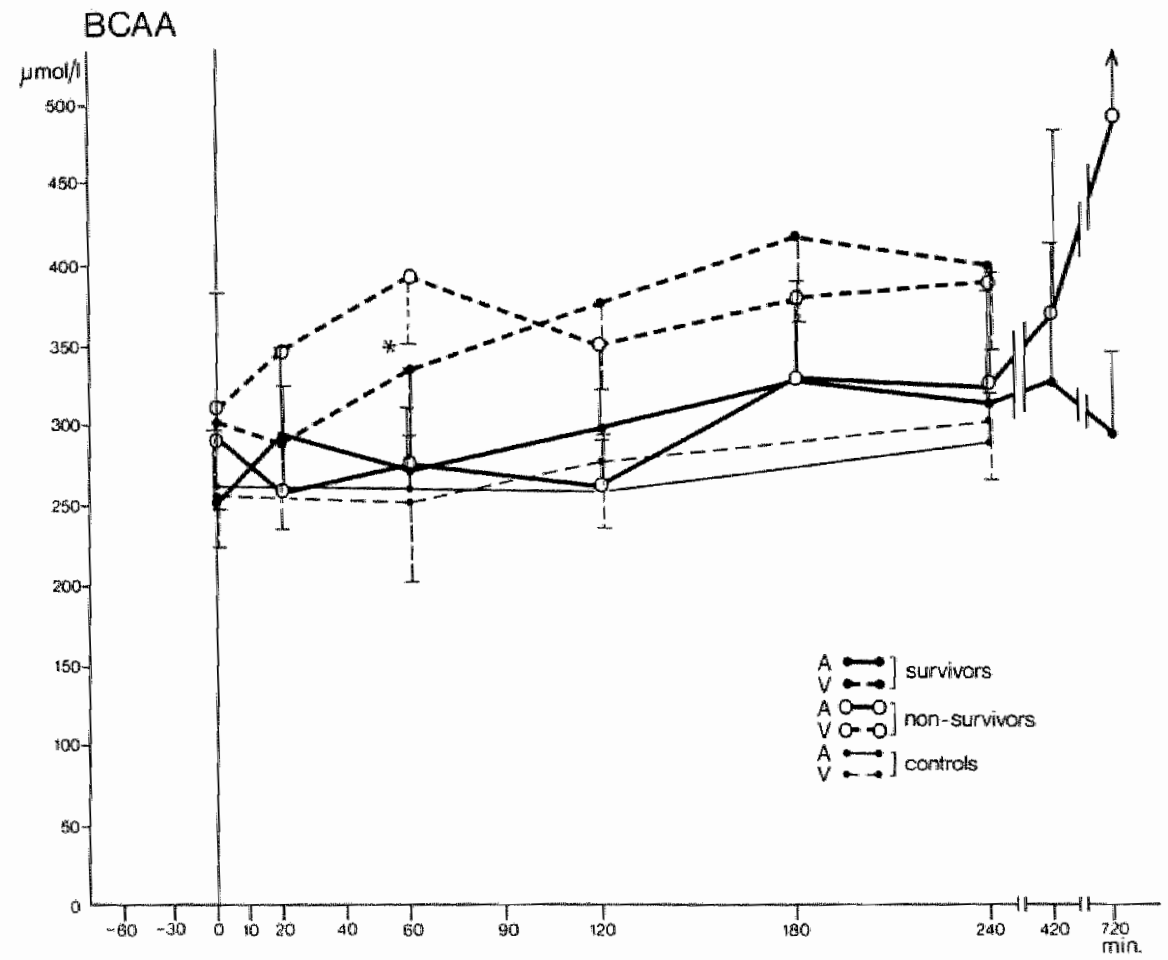

Fig. 5.3-7; Plasma arterial (A) and venous (V) values ( $\mu$ mol/L; mean $\pm S E M$ ) of the branched chain amino acids (BCAA) in controls, survivors and non-survivors.
$p<0.05$
CVS NS
$1=60$
$\mathrm{V}$ 


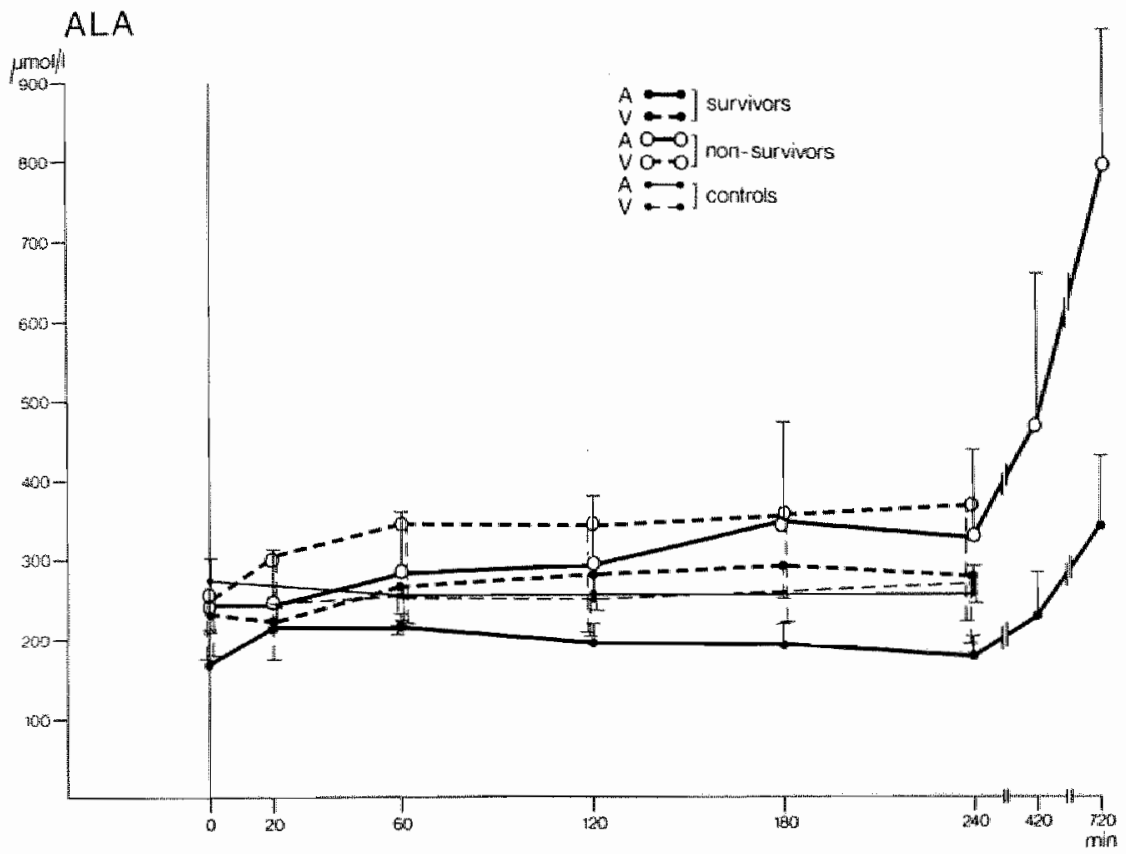

Fig. 5.3-8: Plasma arterial (A) and venous (V) alamine values ( $\mu$ mol/L; mean $\mathbb{E}$ SEM) in controls, survivors and non-Survivors. 


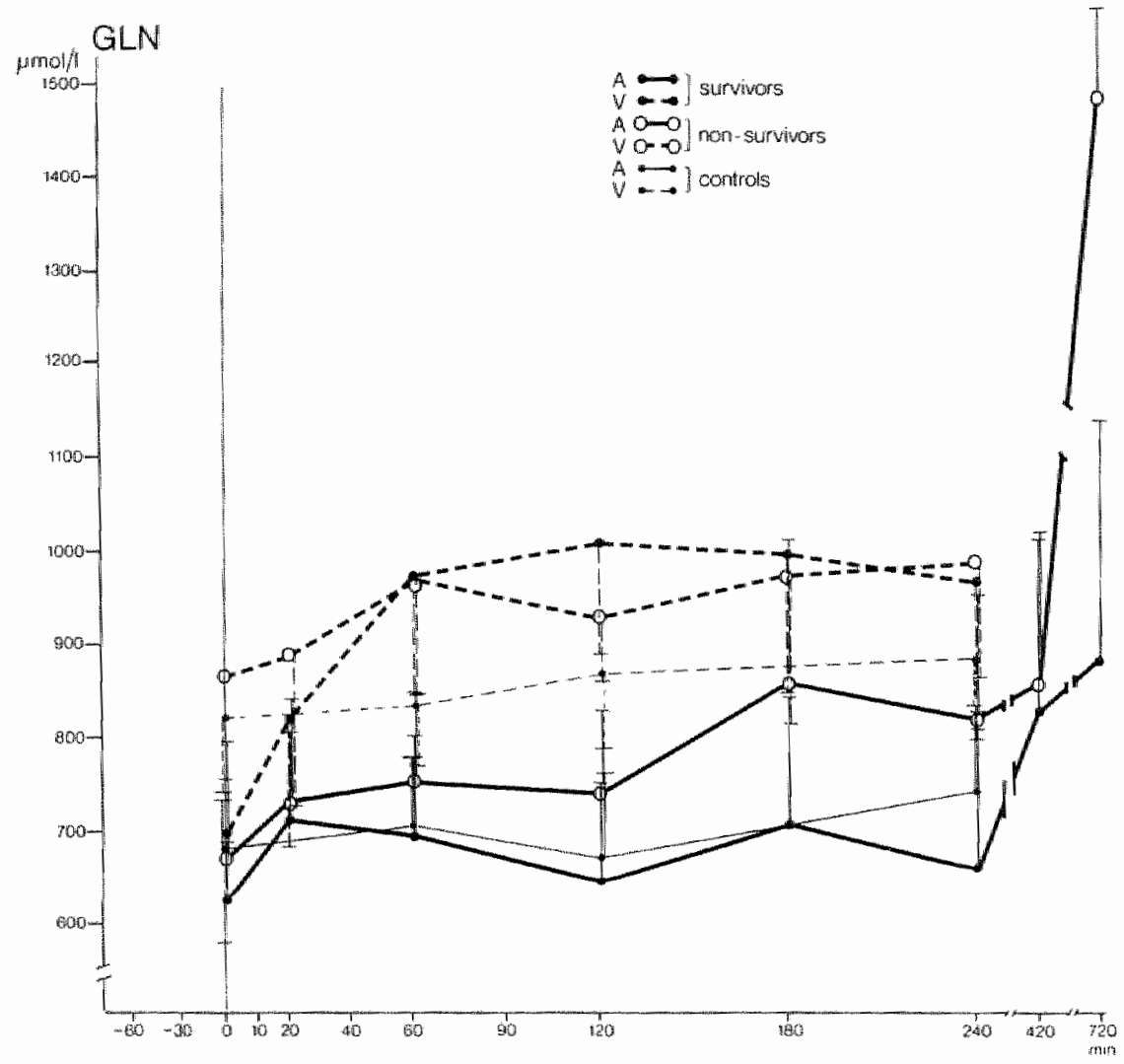

Fig. 5.3-9: Plasma arterial (A) and venous (V) glutamine values ( $\mu$ mol/L; mean it SEM) in controls, survivors and non-surviwors. 


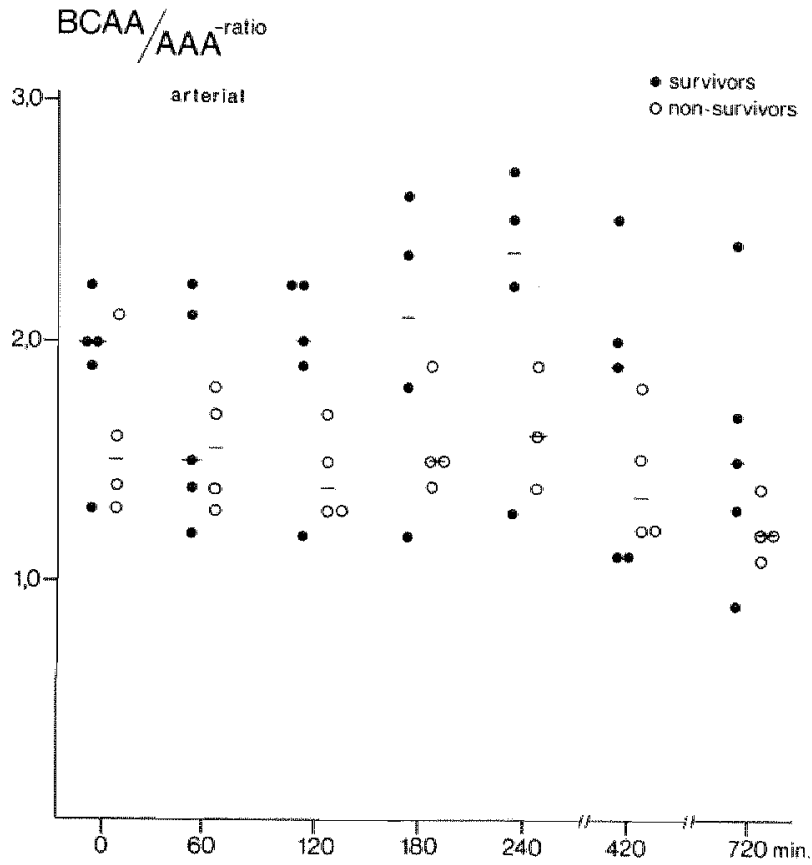

Fig. 5.3-10: The median values in survivors (*) and non-survivors (0) of the arterial BCAA/ AAA-ratio. 
The levels of the amino acids (AA) were not significantly elevated (fig. 5.3-11). The A-fV-differences amounted to 30 to 35 per cent, while in the controls these differences were small. At $t=420$ and 720 in the non-survivors marked arterial and venous elevations of all the amino acids occur, reflecting a massive proteolysis before death and reflecting further deterioration of hepatic function.

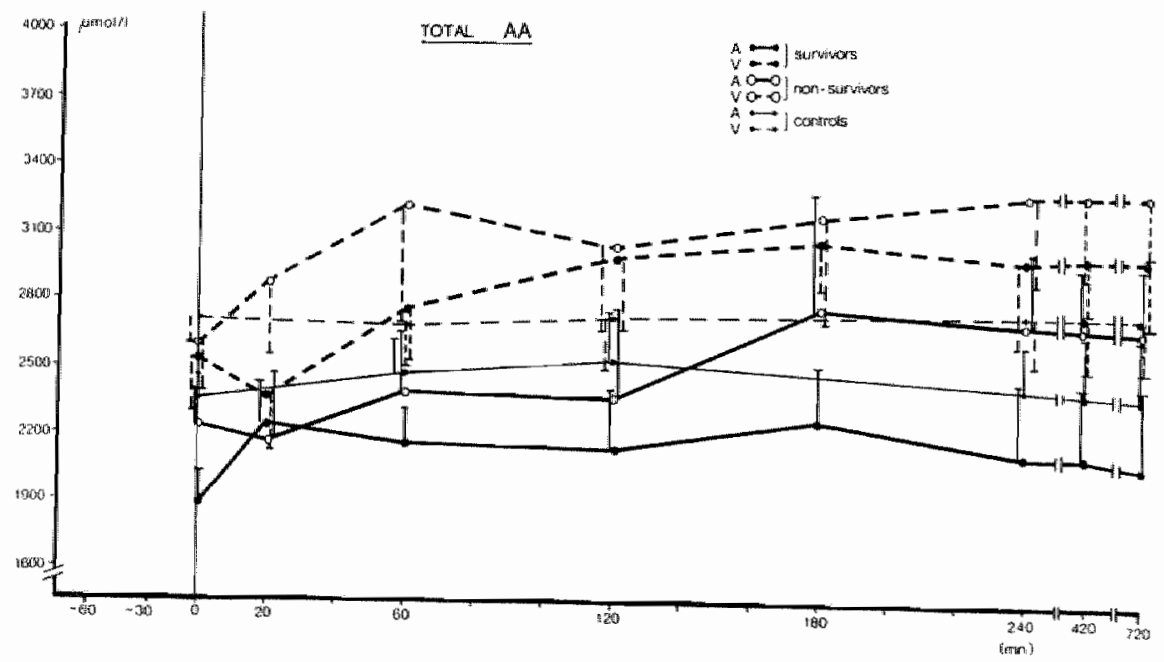

Fig. 5.3-11: Plasma arterial (A) and venous (V) values ( $\mu$ mol/L; mean $\perp$ SEM) of total amino acids (AA) in controls, survivors and non-survivors. 
We determined the clearance rates of the other $A A$, and separately of the BCAA, AAA, Ala and Gin (fig. 5.3-12, 5.3-13, 5.3-14, 5.3-15 and $5.3-16$ respectively). At $t=20$, except for $G \ln$, a remarkable difference between the survivors and non-survivors was evident after $t=20$. An inverse pattern occurred. More negative clearance rates were noted for all amino acids of the survivors versus the non-survivors at or after $t=120$. Especially the levels of Ala and Gln, at $t=120, t=180$ and $t=240$ demonstrate a marked difference, indicating that a considerable uptake occurs in the splanchnic bed, as is required for survival. Compared to the levels of Ala and Gin, the values of the BCAA and AAA at these time points differed less markedly between the survivors and nonsurvivors, indicating once more an accellerated uptake of Ala and Gln under these circumstances. Also the AAA which depend on the liver for their metabolism reveal the same pattern.

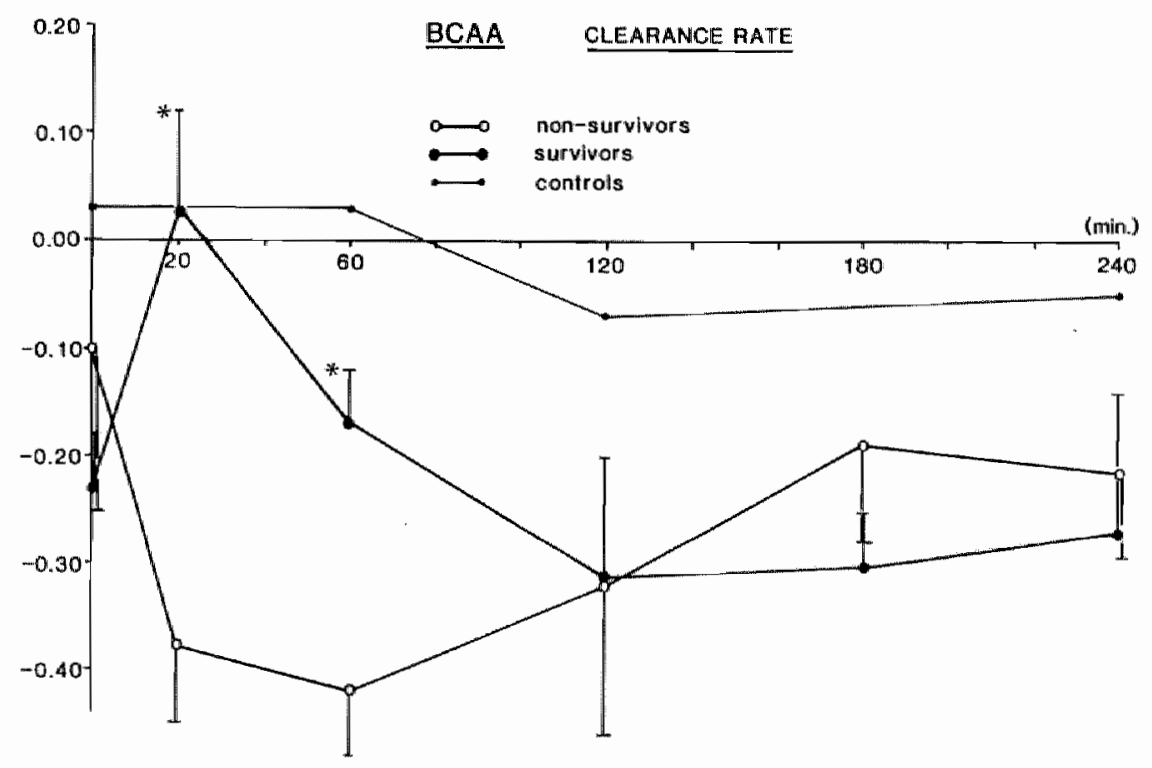

Fig. 5.3-12: Clearance rate of BCAA in controls, survivors and non-5urvivors. $\mathrm{p}<0.05 \quad$ Sis NS $\mathrm{t}=20,60$ 


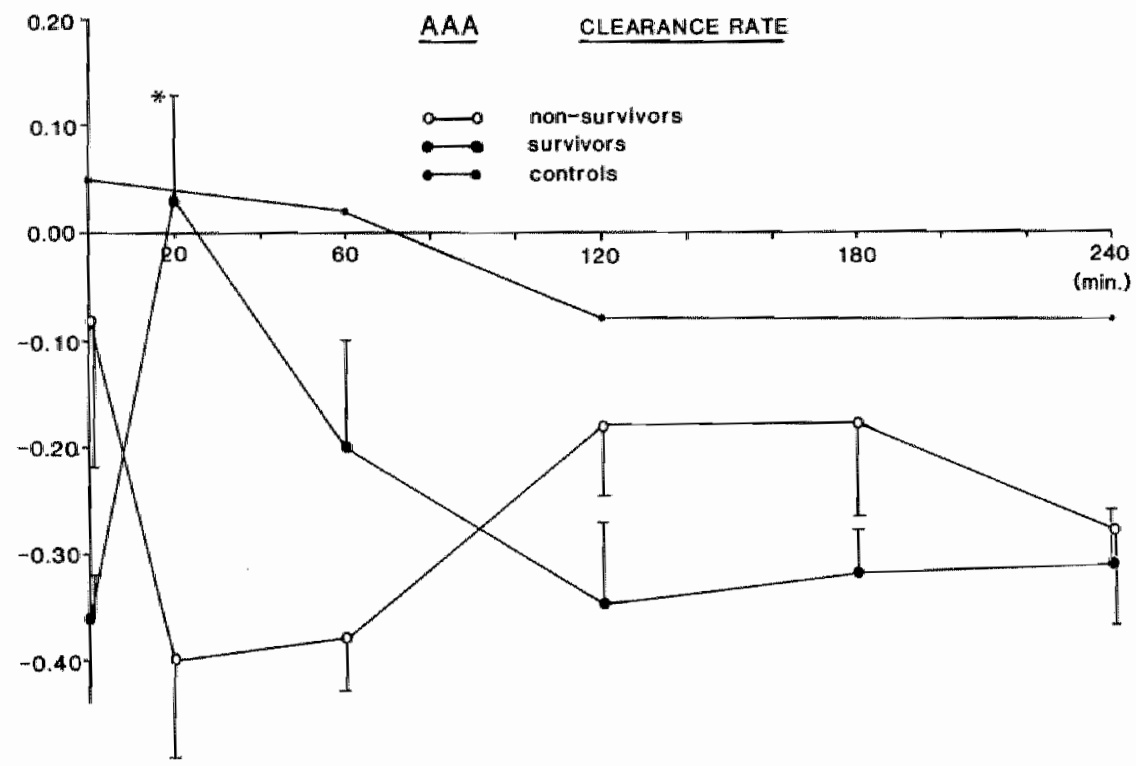

Fig. 5,3-13; Clearance rate of AAA in controls, survivors and non-survivors. $p<0.05$ S vs NS $t=20$ 


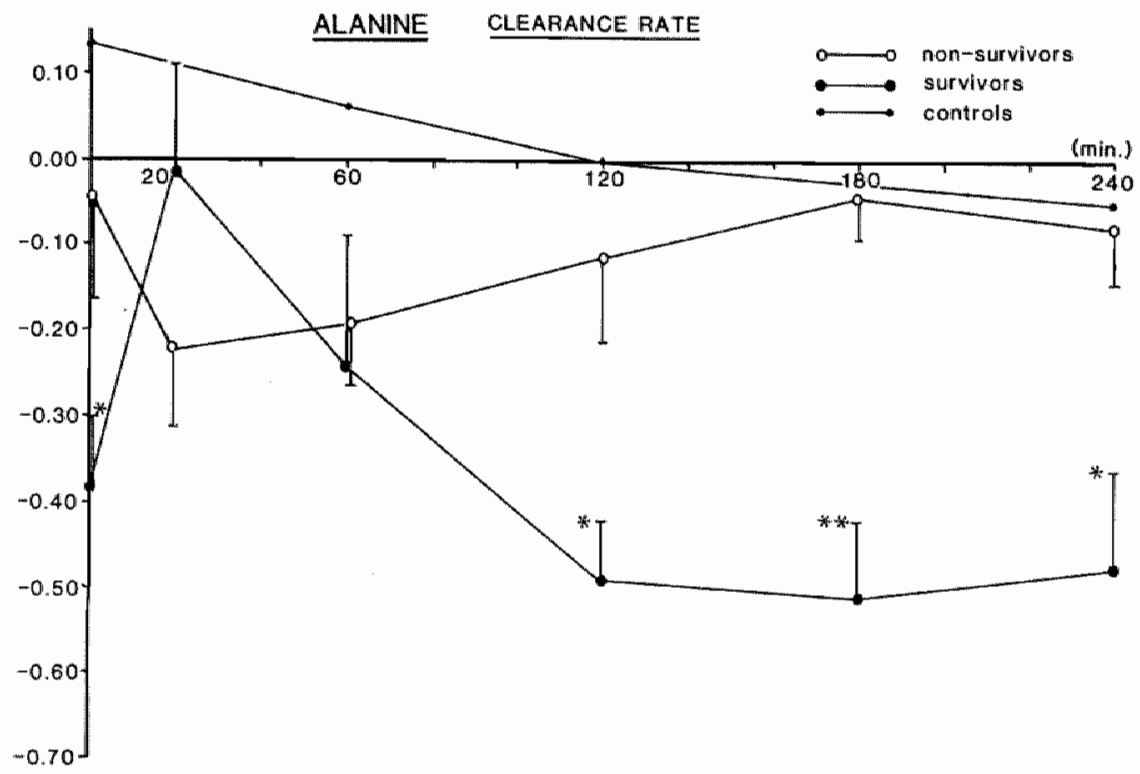

Fig. 5.3-14: Clearance rate of alanine in controls, surwiwors and non-survivors.
$\mathrm{p}<0.01$
S ws NS
$t=180$
$p<0.05 \quad S$ ws NS
$\mathrm{t}=120,240$ 


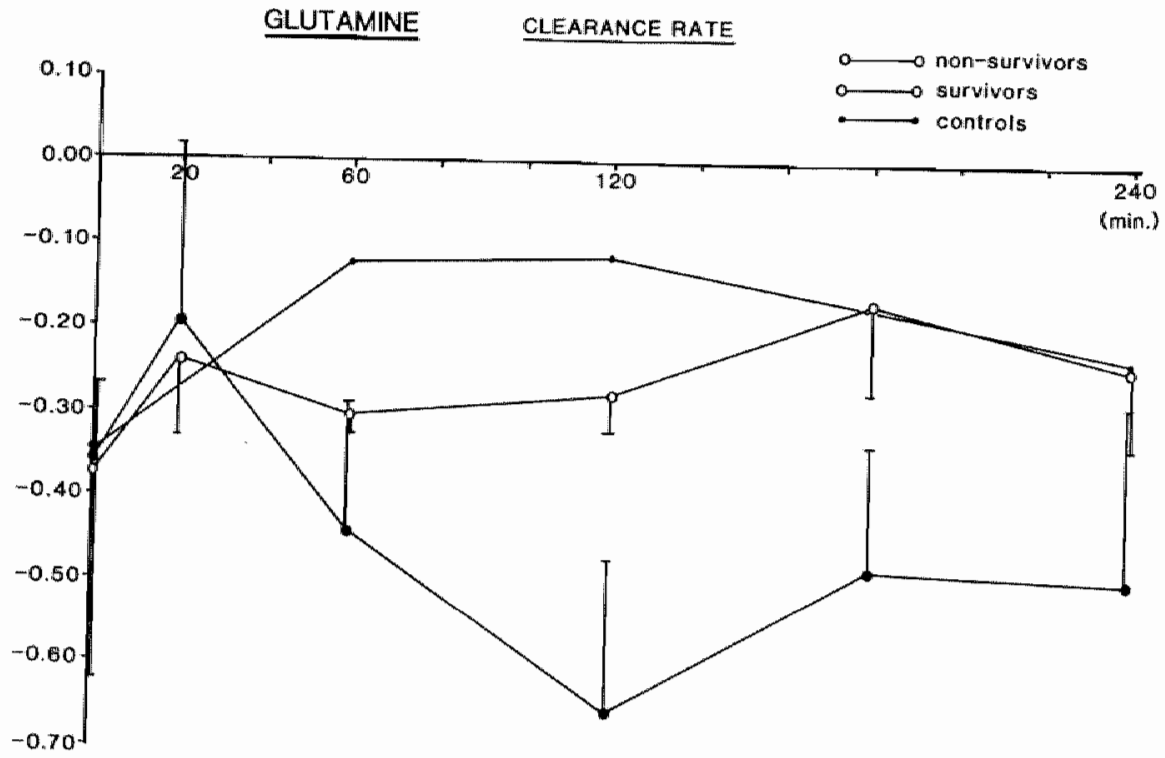

Fig 5.3-15: Clearance rake of glutamine in controls, survivors and non-surviwors. 


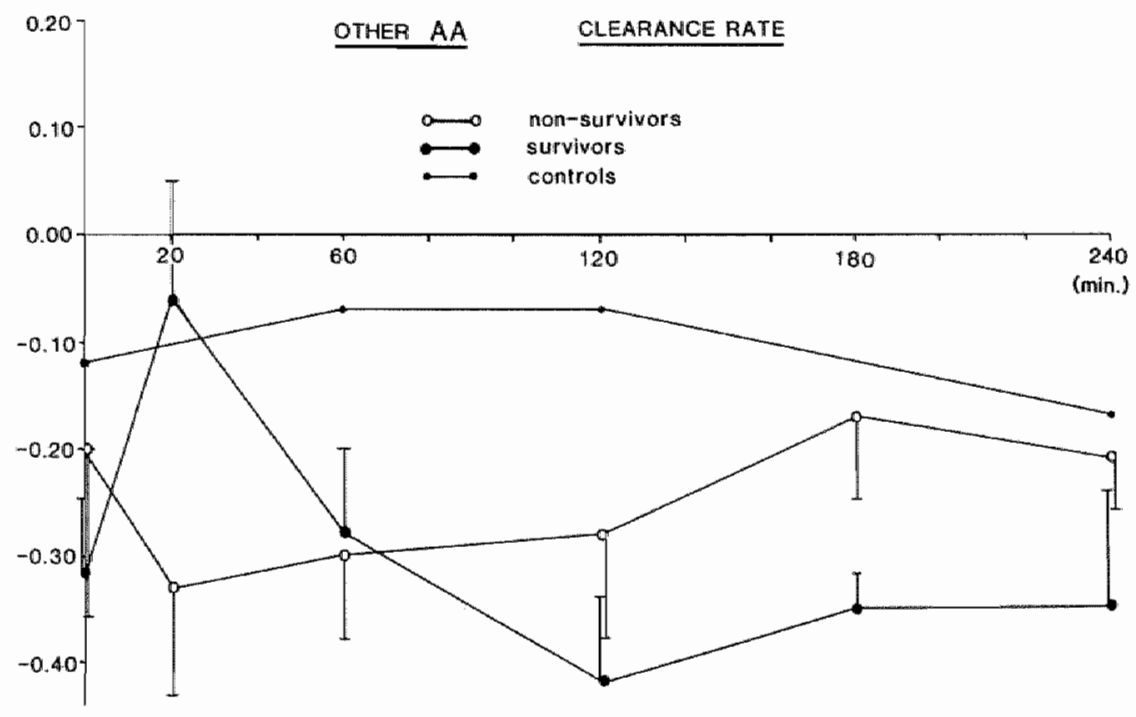

Fig. 5.3-16: Clearance rate of the other $A A$ in controls, survivors and non-surviwors. 
- Ammonia.

In the controls and in the occluded group a consistent positive A-fVdifference was noted (fig. 5.3-17). Ammonia values at $t=-30$ and $t=0$ differed appreciably between survivors and non-survivors, probably due to the inter-individual differences of the dogs one week after shunting. Especially in the occluded group the positive A-fV difference appeared greater after 60 minutes than in the controls. Only exceptionally a venous sample demonstrated a higher value than the corresponding arterial one. Remarkable in comparison to the controls were the maintained elevated arterial ammonia levels in the occluded group. This pattern did not exist in the venous samples, so that a considerable ammoniauptake must have occurred peripherally. At $t=-30, t=0, t=20$ and $t=60$ arterial levels were slightly higher in the non-survivors than in the survivors, not significantly however. Thereafter values were almost exactly comparable to and not higher than pre-occlusion values. Only at $t=420$ a slight increase in arterial ammonia level was noted both in survivors and non-survivors. A-fV values tended to be higher in nonsurvivors at all time points.

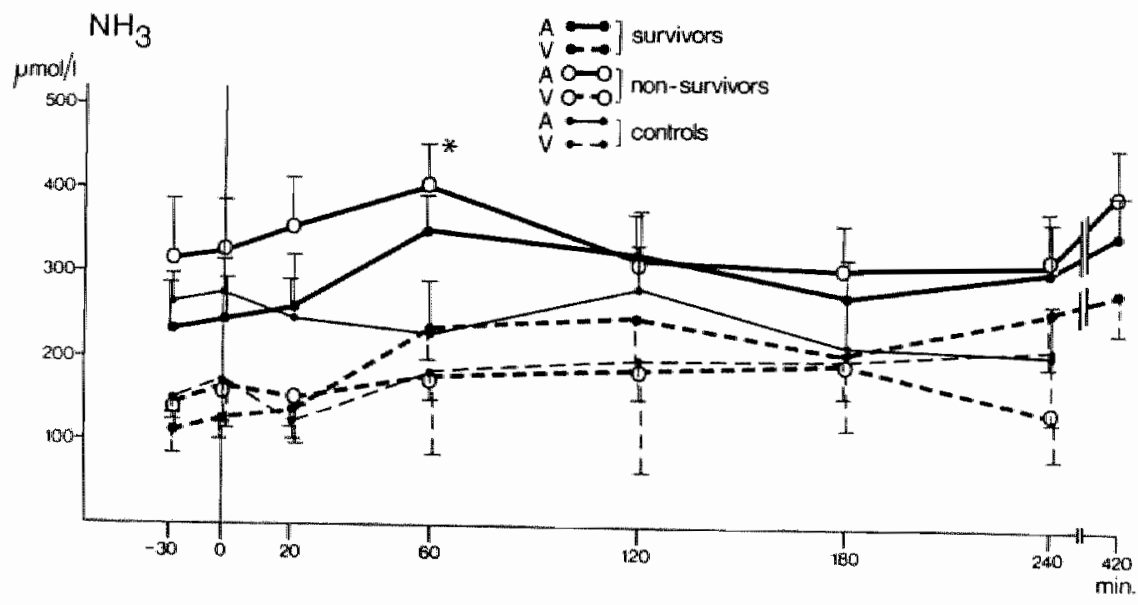

Fig. 5.3-17: Plasma arterial (A) and venous (V) values ( $\mu$ mol/L; mean $\pm S E M)$ of ammonia in controls, survivors and non-survivors.
$p<0.05$
C vs NS
$\mathrm{I}=60$ 
- Lactate and pyruvate.

Lactate and pyruvate slightly increased after occlusion compared to controls and to levels at $t=0$ (fig. 5.3-18 and 5.3-19). These levels plateaued from $t=120$ until $t=240$ during anesthesia and thereafter increased significantlly.

Despite marked individual differences, the mean arterial and venous values for pyruvate in the non-survivors were elevated from $t=60 \mathrm{on}$. This pattern was also seen with the mean arterial and venous lactate values which were already elevated however in the non-survivors at

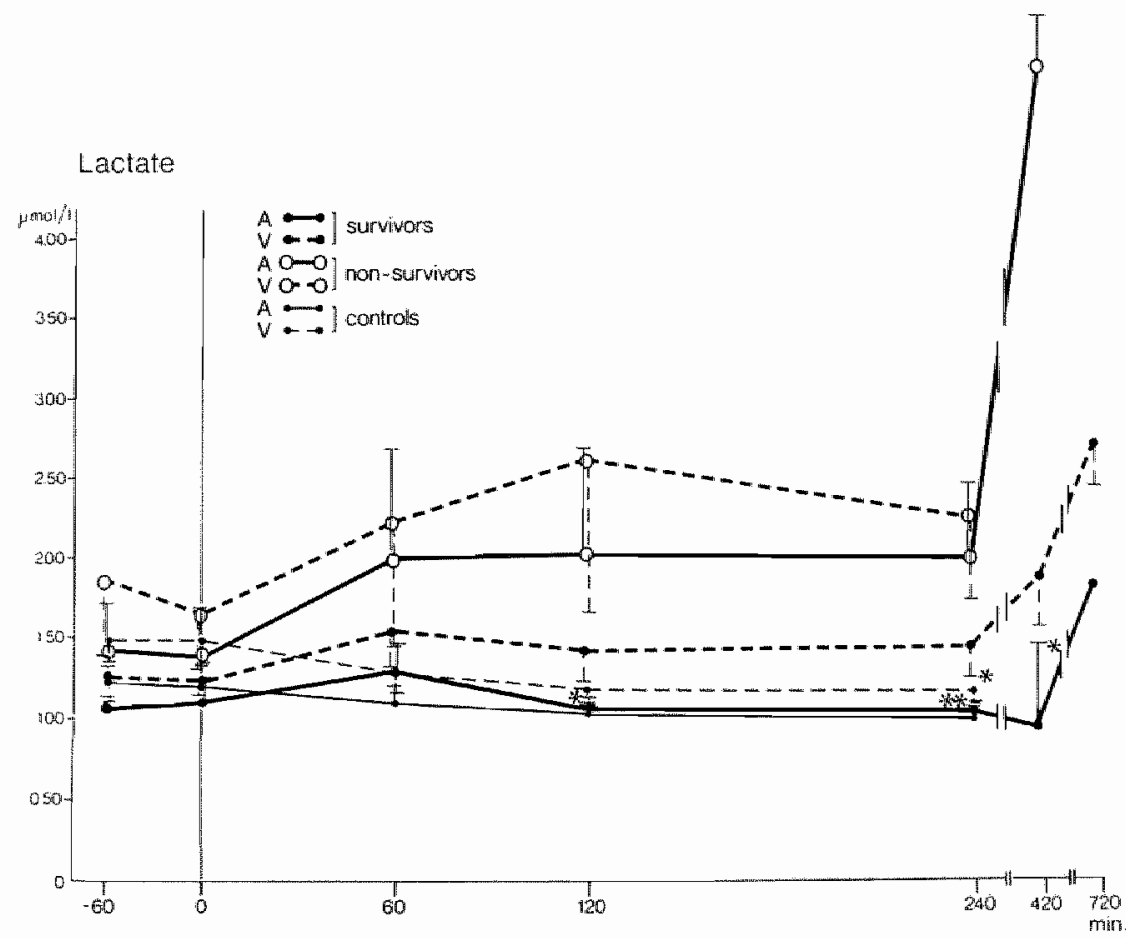

Fig. 5.3-18: Plasma arterial. (A) and venous (V) values ( $\mu$ moll/L", mean $+S E M$ ) of lactate in controls, survivors and non-survivors
$\mathrm{p}<0.01$
$S$ vs NS
$t=240$
A
$p<0.05$
$\mathrm{S}$ vs NS
$t=120,420$
$S$ ws NS $t=240$
A 
$t=-60$ and $t=0$. At $t=0$ the mean arterial lactate/pyruvate-ratio in the survivors and non-survivors was 5.79 and 5.86 respectively. Until $t=240$ a slight decrease occurred, but this impairment was not significant: 4.42 versus 3.90 respectively. The mean venous lactate/pyruvate-ratio also decreased, but again reached no significance, in the survivors from 5.64 to 4.62 , in the non-survivors from 7.28 to 4.44 , respectively.

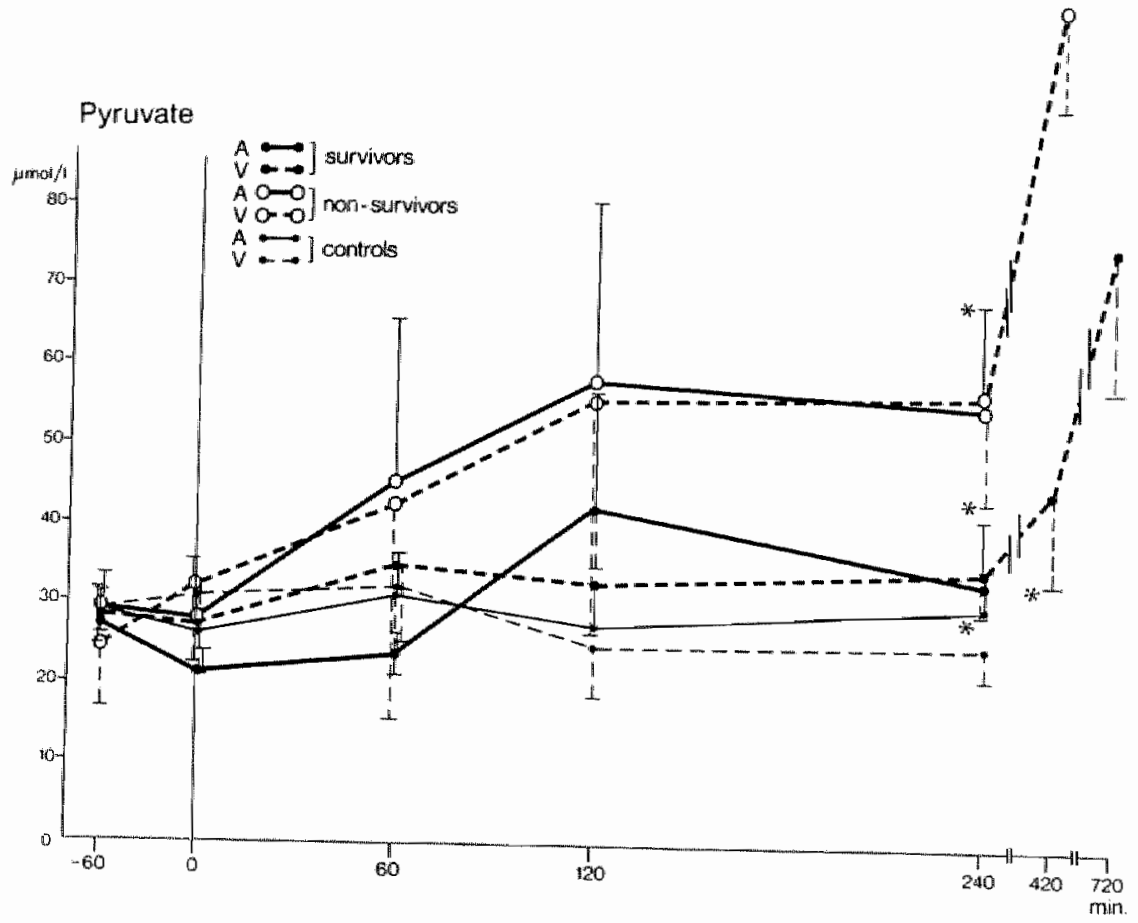

Fig. 5.3-19; Plasma arterial (A) and venous (V) walues ( $\mu$ mol/L; mean $\pm S E M)$ of pyruvate in controls, survivors and noth-survivors.
$p<0.05$
C vs N5
$t=240$
$S$ vs NS $\quad t=240,420$
$A$ and $V$
$\mathrm{V}$ 
- Free fatty acids and total ketone bodies: acetoacetate and beta-hydroxybutyrate.

The behaviour of the ketone bodies, acetoacetate and beta-hydroxybutyrate, was difficult to interpret. No clear pattern could be distinguished and no remarkable differences were determined at $t=0$. Changes in acetoacetate and beta-hydroxybutyrate parallelled roughly those of lactate and pyruvate, but changes were not significant. A slight uptake both in the controls and in the occluded group occurred over the hindleg.

The blood ketone body ratio: acetoacetate/beta-hydroxybutyrate, which has been claimed to reflect the mitochondrial redox potential and may correlate with the hepatic energy charge, presented no evidence for a marked decrease in hepatic energy charge (Ukikusa, 1981 and Ozawa, 1983) (fig. 5.3-20). No differences were found between survivors and non-survivors.

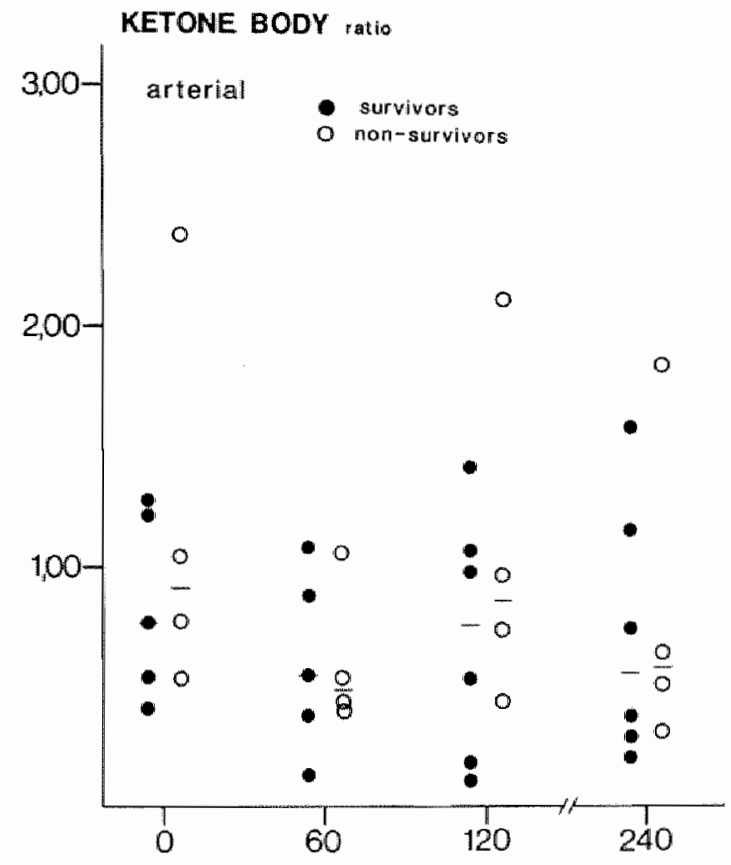

Fig. 5.3-20: The median of the arterial blood ketone body ratio in survivors $(\bullet)$ and nonsurviwors (o). 
F.FA.

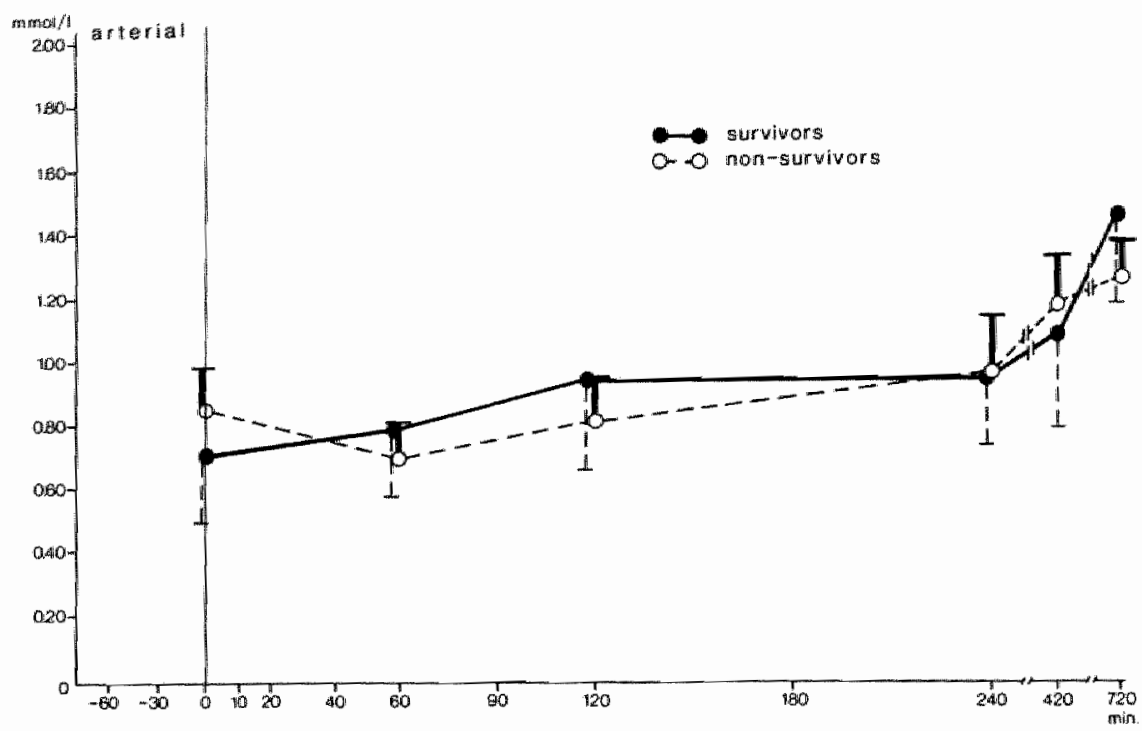

Fig. 5.3-21: Plasma arterial free fatty acid values (mmol/L; mean $t S E M$ ) in survivors (-) and non-survivors (o).

Also arterial free fatty acid levels before, at and after $t=0$ exhibited no marked fluctuations (fig. 5.3-21). As could be expected increased levels were found in a later phase of the experiment. Remarkable increments were detected at $t=240,420$ and 720 , but no significant differences could be detected between survivors and non-survivors.

\subsection{Discussion}

In our model of portacaval shunt and devascularization of the liver, the arterial and venous plasma values of glucagon, insulin, glucose, amino acids and other substrates were sequentially followed. The impairment of glucose homeostasis that has been repeatedly described after hepatic ischemia was only partly confirmed (Lampe, 1971 and Wustrow, 1981). Both in the pilot and in the definitive studies progressive elevations of glucagon occurred, together with normoinsulinemia and a relative hypoglycemia during and after the occlusion. However, a decrease of glucose 
at $t=420$ and 720 especially in the non-surwivors was demonstrated, while only saline was infused. The response of the liver to the high levels of glucagon after withdrawal of the occlusion was probably sufficient to maintain glucose levels albeit at a lower, but not hypoglycemic level. Thus, the recovery of the liver after revascularization and a persistent hyperglucagonemia, in the presence of insulin, maintained relatively adequate glucose levels. Also during occlusion no clear hypoglycemia was noted. This suggests that at least some flow to and from the liver must have been preserved. However a potential additional source of glucose is the kidney which may produce approximately $1 \mathrm{~g}$ of glucose $/ \mathrm{kg} \mathrm{BW} / 24 \mathrm{hr}$ (Lefebvre, 1979).

The roles of insulin and glucagon in the regulation of basal glucose production in the postabsorptive or overnight fasted dogs have been extensively studied by the group of Cherrington (Cherrington, 1976; Jennings, 1977; Cherrington, 1978, 1979 and 1981). A deficiency of one or both pancreatic hormones was achieved by infusing somatostatin, a potent inhibitor of both insulin and glucagon secretion, alone or in combination with intraportal replacement infusions of one pancreatic hormone. A basic conclusion from these studies was that the basal glucagon level is responsible for approximately 65 per cent of glucose production and its primary role is stimulating glycogenolysis. Furthermore, basal glucagon appeared to be essential in maintaining normal glucose production and euglycemia if insulin is present, while appropriate insulin levels prevent increase of glucose production which would result from the unrestrained action of glucagon. These findings support the sequence of events in our dogs. Both in the survivors as well as in the non-survivors, although with striking inter-individual differences in the two groups, a persistent hyperglucagonemia was demonstrated.

From the literature it is clear that hyperglucagonemia is a result of hypersecretion, not from decreased breakdown (Marco, 1973; Sherwin, 1974 and 1978; McDonald, 1979; Keller, 1982; Kabadi, 1984). From a theoretical point of view in liver injury hyperglucagonemia does seem to play a useful adaptive role in maintaining the capacity of the compromized liver for gluconeogenesis and glycogenolysis. In the absence of stress and diabetes, the plasma glucose concentration is the most important factor in the regulation of glucagon secretion between meals (Park, 1972). The A-cell response to stimuli is greatly altered by glucose (Eigler, 1979). Substances that normally stimulate glucagon secretion, such as amino acids and certain gut hormones, fail to do so during hyperglycemia (Unger, 1969 and 1981). Only during stress glycemia has no dominant influence on A-cell function. At the same time glucagon has long lasting effects 
on plasma amino acid levels primarily by augmenting the rate of hepatic gluconeogenesis (Boden, 1984).

In our study theoretically two types of substrates may have been responsible for the hyperglucagonemia observed, namely glucose levels and amino acid levels. Obviously it is impossible to conclude from such a study what is the primary determinant, even more so because amino acids, notably alanine and glutamine, glucose and pancreatic hormones act in concert to achieve homeostasis (Soeters, 1984). We found that at $t=40$ plasma glucagon rises while euglycemia is maintained. At the same time release of alanine over the hindleg is increased whereas arterial levels do not rise dramatically, indicating that alanine is metabolized at this stage. Similarly peripheral uptake of glucose occurs, proving that glucose is still produced. After $t=60$ glucose levels start to fall, hyperglucagonemia intensifies, glucose uptake persists peripherally whereas alanine and glutamine are still released peripherally. At this stage the rise of lactate levels is more pronounced in the non-surviving group than in the survivors although peripheral release is comparable. This suggests that the liver in the non-surviving animals cannot metabolize lactate sufficiently. It should be emphasized however that in the non-survivors lactate levels and glutamine release is already increased at $t=0, t=10$ and when measured before occlusion. This may indicate that the non-survivors had tolerated the portacaval shunt less well than the survivors and that this may eventually have had an important influence on outcome. Increased glutamine release and decreased Jactate clearance from the liver at these early timepoints indicate that the non-surviving group was already catabolic at this stage and had diminished hepatic function.

Catecholamine levels differed also at the early timepoints. Epinephrine levels in non-survivors were higher than in survivors from $t=20$. Before that timepoint no appreciable differences were apparent. Norepinephrine levels however differed already before occlusion and the difference persisted also suggesting that the non-surviving group was already more stressed before occlusion.

At $t=90,120,180$ and 240 hyperglucagonemia persists whereas relative hypoglycemia develops becoming more pronounced in the non-surviving group compared to the survivors. Coinciding with this is the striking phenomenon that release of glutamine and alanine increases in the survivors whereas it diminishes in the non-survivors. This is in accordance with the findings of Clowes (1984), namely that survival of liver patients during stress or trauma, is related to their ability to generate a release of alpha- 
amino-nitrogen from muscle. This in his wiew means, assuming that a steady state exists, that the liver uses these amino acids for the synthesis of proteins operative in the response to injury (Clowes, 1985). Apparently non-survivors were allready challenged before occlusion and, when subjected to the trauma of occlusion, could not keep up a flow response of amino acids resulting in death.

Clearance rates illustrate even beter the phenomena described. Clearance rates of the sum of all AA is greater at $t=0$ for non-survivors than in survivors. This may indicate that non-survivors were already stressed at this stage. Hereafter a gradual decline in clearance rates occurs in nonsurviving dogs whereas survivors have an increased clearance rate, which indicates that hepatic function is preserved. We may conclude this only when a steady state exists namely that all AA released peripherally are indeed metabolized by the liver. This most likely applies for surviving dogs because their arterial free AA levels did not increase substantially from $t=20$ to $t=240$. If we assume that arterial AA levels are representative for the total body pool of free AA, no free AA must have accumulated in survivors. The contrary is true in non-surviving dogs where arterial free AA levels increase. Consequently clearance rate in non-survivors (already low at $t=120$ to $t=240$ ) must have been overestimated. This therefore signifies that constant arterial free AA levels" and an increased clearance rate have a favourable prognostic value. This applies also more or less for the individual AA. Results however are most significant for alanine.

The central role of alanine, a strong A-cell secretagogue, in the operation of metabolic cycles in skeletal muscle and the interrelationship with gluconeogenesis in the liver led to the concept of a glucose-alanine cycle that operates to maintain glucose homeostasis (Felig, 1973). In the liver, alanine represents the most important protein derived gluconeogenetic precursor. Glucose synthesized by the liver from alanine, can then be taken up again by muscle and can be converted back to pyruvate and subsequently to alanine. Studies in dogs (Shulman, 1980) and in man (Robert, 1982) supported the concept that hypoglycemia per se, independent of insulin and/or glucagon secretion, increased the rate of alanine entry into the circulation. This was not confirmed in our study. Despite a relative hypoglycemia which tended to be more severe in the non-survivors than in the survivors peripheral alanine release was lower in the non-survivors than in the survivors. Therefore the inability of the liver to produce glucose must in some way signal the peripheral tissues not to release alanine. Arterial alanine levels, higher in the non-survivors than in the survivors may fulfill this role. 
Fischer (1976) has advocated the ratio between plasma levels of BCAA and AAA as a measure of liver failure and more specifically encephalopathy. This ratio showed, in arterial blood, a tendency to be increased in the survivors compared to the non-survivors at all time points including $t=0$, but with exception of $t=60$. Scrutiny of arterial BCAA levels reveals that no consistent differences occur from $t=0$ to $t=240$. The difference noted in the BCAA/AAA-ratio therefore largely reflects changes in arterial AAA levels. Although the arterial AAA levels exhibited a consistent tendency to rise in non-surviving dogs in comparison with the levels in surviving dogs, which remained stable, no significance was reached due to the large interindividual variations. This precludes the use of the arterial AAA levels c.q. the arterial BCAA/AAA-ratio as a predictor of survival.

As previously described glutamine exhibits a similar behaviour as alanine. In non-survivors peripheral glutamine release diminishes compared to survivors. Again higher arterial glutamine levels in non-survivors may provide the signal to decrease release. Glutamine also plays an important role in a cycle between peripheral tissues and the splanchnic area. Glutamine and alanine contain over $60 \%$ of the alpha-aminonitrogen derived from peripheral proteolysis and serve as non toxic nitrogen carriers. Glutamine is quantitatively the most important, firstly because the glutamine/alanine ratio in venous blood derived from peripheral tissues varies between $3: 2$ and $2: 1$, and secondly because glutamine contains two nitrogen atoms. Subsequently glutamine is taken up by two organs, namely the gut and the kidney. In these organs uptake of glutamine results in production of alanine and ammonia. In this way glutamine participates in the glucosealanine cycle, and shuttles both carbon and nitrogen derived from catabolism in peripheral tissues in a harmless manner via the gut to the liver. The glutamine-alanine ratio is influenced by arterial ammonia (Imler, 1982). When more ammonia is presented to the peripheral tissues more glutamine and less alanine results. Ammonia is taken up and with glutamic acid forms glutamine. This was not observed in our study. Despite increased peripheral ammonia uptake in the non-survivors, this did not result in an increased glutamine/alanine ratio in venous blood. The increase in arterial glutamine level in the non-survivors compared to the survivors may however have been caused by increased ammonia uptake. It is not clear however, why the excess of arterial glutamine in the non-survivors is not metabolized in the gut. Regulation of this process in the gut is not completely elucidated however.

Analagous to the concept of the glucose-alanine cycle lactate is processed 
in the glucose-lactate (Cori-)cycle. The values for lactate parallelled those of pyruvate in the survivors and the non-survivors. This implicates that no significant difference occurred in the lactate/pyruvate ratio between survivors and non-survivors. In the non-survivors absolute levels increase however after occlusion, suggesting that the liver is not able to process lactate and pyruvate and to form glucose in non-survivors, whereas A$\mathrm{fV}$-differences demonstrate that lactate is released at all timepoints measured. It is important however to note that arterial and venous lactate levels were already elevated in non-survivors compared to survivors before occlusion. This suggests that non-survivors had tolerated the portacaval shunt less well than survivors (Lauterburg, 1976). In a similar way this was suggested for alanine and glutamine release from peripheral tissues. After portacaval shunt, reductions of more than $80 \%$ in hepatic cholesterol and triglyceride synthesis were demonstrated in dogs and in humans (Starzl, 1976). To ascertain whether portal diversion affects ketone body (KB) metabolism, Federspil (1980) measured free fatty acids (FFA), acetoacetate (AcAc) and beta-hydroxybutyrate (3-OH-B) in portacaval shunted rats. $\mathrm{KB}$ concentration and $3-\mathrm{OH}-\mathrm{B}$ were significantly lowered in these rats, while AcAc concentration did not appear significantly modified. Probably hypoketonemia is induced by portal diversion due to reduced hepatic availability of fatty acids. The mechanism underlying this reduction is not clear. Nosadini (1984) furnished evidence that a low insulin / glucagon ratio increases KB-production in the liver. Elevations in plasma free fatty acids (FFA) during fasting have been attributed to low insulin levels, while conversely reduced plasma FFA levels after feeding were explained by the increase of insulin and glucose concentrations. In our dogs an increase of FFA due to the progressive hyperglucagonemia would be expected. However, during the occlusion the extra-hepatic uptake of FFA was probably such, that no elevated FFA levels were present. Prolonged metabolic stress however, concomitant with the persistent hyperglucagonemia leads to increased FFA levels at $t=420$ and $720 \mathrm{~min}$. Bernal (1982) discussed the regulation by insulin and described that plasma insulin levels do not change enough to account for the initiation of FFA mobilization. Their results suggested a hepatic factor, which lowered FFA mobilization from adipose tissue.

In the literature, the KB-ratio has been advocated as an indirect measure of the energy charge of the liver (Ukikusa, 1981; Ozawa, 1983). Under normal aerobic conditions, the energy charge of the cel\| is maintained at a high and constant level. The KB-ratio positively correlates with the hepatic energy charge. The ratio of $A c A c$ and $3-O H-B$ in the liver is in equilibrium with the hepatic mitochondrial free micotinamide adenine 
dinucleotide $(\mathrm{NAD})^{+}-\mathrm{NAD}$ dehydrogenase (NADH) ratio, which is closely related to oxidative phosphorylation. Since AcAc and 3-OH-B freely pass through the cell membrane, the KB-ratio in arterial blood may be used as an indicator of the $\mathrm{KB}$-ratio in the liver. When energy-generating sequences are insufficient, the energy charge decreases. Thus, energy charge is a convenient parameter to indicate the intracellular energy status in vivo at any given time. Diminution of mitochondrial function of the liver in the course of anoxemia is plausible, thus the mitochondrial redox state expressed as a ketone body ratio, should be decreased. The results of our determinations of the ketonebodies were not impressive and no differences tended to occur between survivors and non-survivors precluding the ketone body ratio as a predictor of outcome. A possible explanation may be that under the experimental conditions no free exchange of ketone bodies occurs between the liver and the systemic circulation.

In conclusion:

1. Non-surviving dogs had tolerated the portacaval shunt less well than the surviving dogs. Arterial insulin (significantly at $t=10$ and $t=20$ ) and norepinephrine levels were increased in the non-survivors. Similarly alanine clearance in the non-survivors was significantly lower than in survivors. Furthermore peripheral ammonia uptake, arterial lactate and AAA levels exhibited trends to be increased in non survivors.

2. After occlusion several differences could be noted between survivors and non-survivors:

- The most significant differences were found in alanine clearance, which was already significantly higher at $t=120$ after occlusion in the surviving group, whereas arterial alanine levels remained stable.

- Arterial lactate levels were higher in non-survivors than in survivors, but significantly only at $t=240$.

- Other amino acids clearances (total AA, Gln, AAA, other AA) exhibited similar behaviour as alanine clearance, but no significant differences were reached between survivors and non-survivors.

3. Severtal parameters claimed to allow estimation of liver failure or/and encephalopathy did not correctly distinguish between survivors and nonsurvivors.

- The plasma BCAA/AAA ratio was on average lower in non-surviving dogs, but exclusively due to increases in arterial AAA levels. Due to the large standard deviation these levels could not be used as parameters correctly distinguishing between dogs that were to die or survive. 
- The ketone body ratio did not differ between survivors and nonsurvivors.

- Peripheral ammonia uptake tended to be greater in non-survivors from early on $(t=-30, t=0)$. No significance was reached and at no point in time were venous or arterial levels appreciably different between non-survivors and survivors.

- The lactate/pyruvate ratio was not significantly different between groups.

4. These results suggest that it may be worthwile to explore the value of alanine clearance rates in patients undergoing severe hepatic insults (acute fulminant viral hepatitis, acute paracetamol hepatitis, deteriorating liver cirrhosis, etc.) and furthermore to pay more attention to lactate levels. 



\section{Enzymatic and pathological aspects of acute hepatic ischemia in dogs}

\subsection{Introduction}

The liver is sensitive to hypoxia, and different metabolic and structural changes at the cellular and subcellular level rapidly occur during and after liver ischemia (De Duve, 1959). Acute liver failure of varying etiology has been associated with hypoxia and cell death.

The most common cause of acute liver failure in man is viral hepatitis (virus $A$, virus $B$, non-A non-B viruses). Other causes vary, mostly according to the geographic location. Several potentially toxic drugs, like paracetamol, are responsible for a broad spectrum of abnormalities, leading to the characteristics of the syndrome of acute hepatic failure. In man, liver cell damage is present throughout the lobule and demonstrates considerable variation. The diagnosis is based on the co-existence of various morphologic abnormalities. It is most striking in the centrilobular area, zone 3 of Rappaport (1973). There are only a few studies in dogs reporting acute and chronic histological changes of the liver after different periods of total ischemia. In considering the histological features caused by the occlusion in our dogs, we have to take into account the effects of diversion of portal blood to the systemic circulation on hepatocellular function and structure. Studies claiming that hepatic damage can be detected histologically before elevations of enzyme activity occur in plasma are still controversial. In our study sequential measurements of several enzymes in plasma were performed. Liver biopsies were taken within 24 hours after occlusion and after 2,4 and 6 weeks.

\subsection{Enzymatic patterns of acute hepatic ischemia}

Figure 6.2-1 shows plasma CK values after the initial devascularization procedure and after a period of hepatic artery occlusion. The elevations after devascularization can be readily explained by skeletal muscle damage during surgery. The much higher elevations after hepatic artery occlusion are however surprising, because the liver hardly contains CK and the 


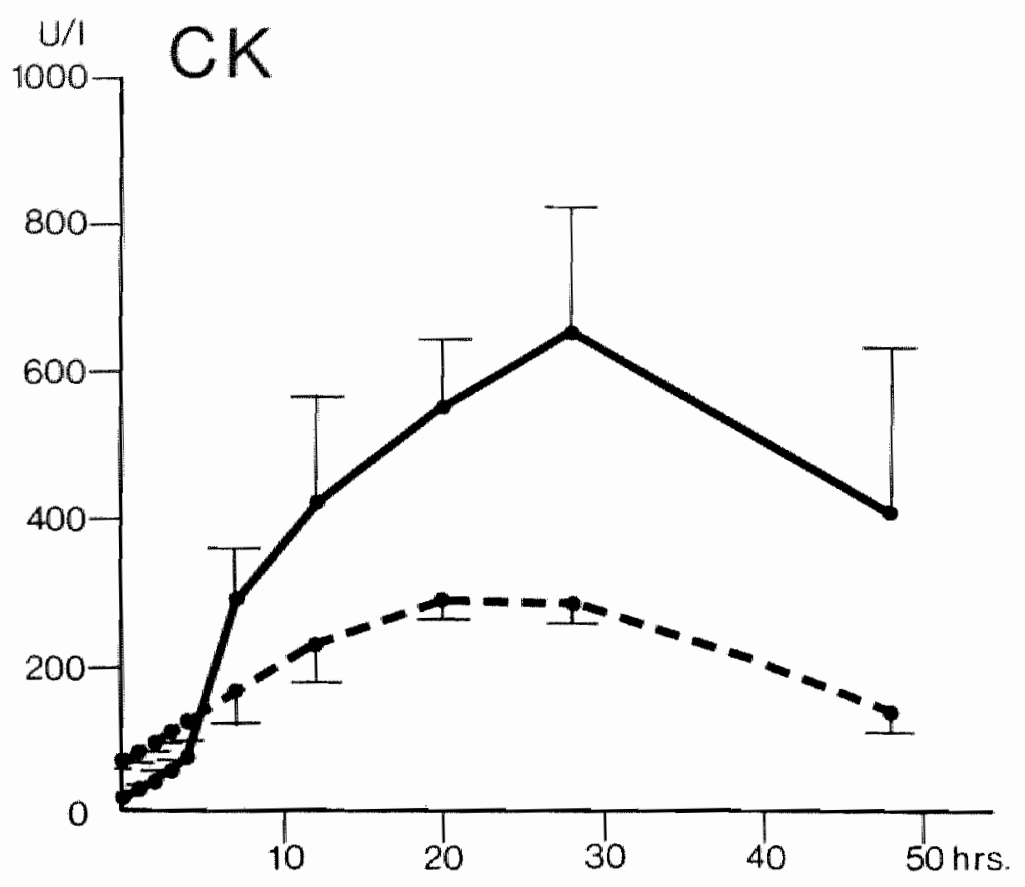

Fig. 6.2-1 Plasma CK-values (U/L; mean \pm SEM) after initial devascularization $(\bullet-\ldots)$ and after hepatic artery acclusion (-)

acclusion procedure does not directly damage skeletal muscle. The somewhat delayed release in this case suggests muscle damage accurring some hours after occlusion when the dogs are regaining consciousness after anesthesia. Indeed, some damage could occur in this period because the dogs are for some time stumbling and bumping into objects, but it is surprising to find the effect larger than during the previous recovery from surgery. The effect could be explained by a decrease of the rate of elimination of $\mathrm{CK}$ from plasma as a result of liver injury.

Figure 6.2-2 shows post-occlusion elevations of plasma AST and ALT activity in four dogs that died within 12 hours after acclusion (upper panel) and four dogs surviving for at least 5 days (lower panel). A logarithmic plot was adopted in order to cover the wide range of activities. The survivors were matched to the non-survivors by taking the previous survivor to each non-survivor. Although the number of cases is too small for final conclusions, a few trends are apparent from figure 6.2-2. The onset of enzyme 

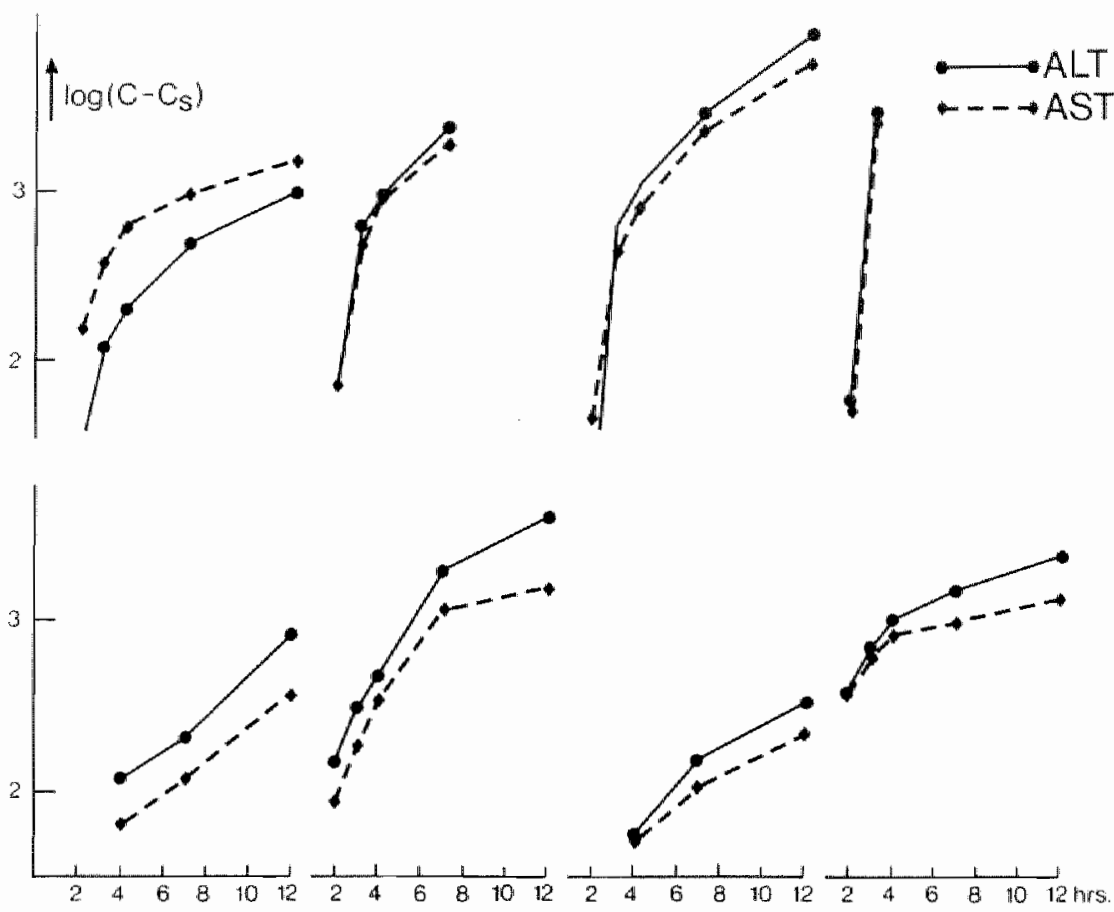

Fig. 6.2-2: Plasma AST and ALT activities in four dogs that died (upper panel) and four surviving dogs (lower panel).

release is more sudden and massive in the non-survivors and this is especially true for AST. In the surviving group the release of AST is more sluggish and trails behind the release of ALT.

Plasma activities of GLDH, determined in the dogs shown in figure 6.2-2, never exceeded $10 \%$ of ALT activities during the first 12 hours after occlusion.

\section{Enzymatic quantitation of acute liver injury}

Figures 6.2-3 and 6.2-4 present mean plasma activities and calculated cumulative release of ALT and AST after temporary hepatic artery occlusion $(n=17)$ and in controls $(n=7)$. The hump noted in the curves (fig. 6.2-3) after 9 hours is largely caused by the drop out of non-survivors.

Table 6-1 presents the numerical values of $Q_{A L T}$ as a function of time after temporary ischemia. It is noted that the ratio $Q_{A S T} / Q_{A L T}$ reaches the expected value of 0.6 after 5 days (see discussion in 6.4). 


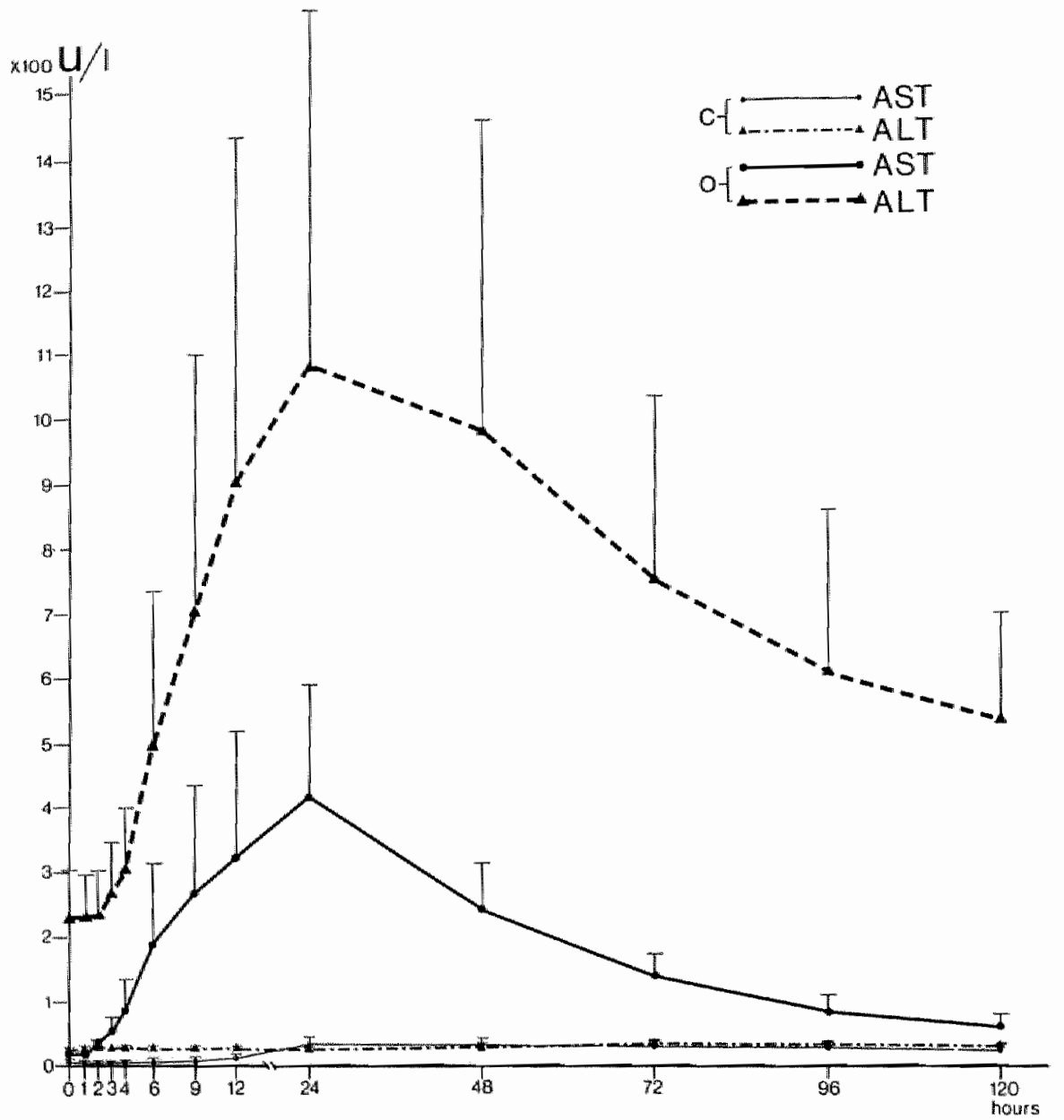

Fig. 6.2-3. Plasma activities of ALT and AST in U/L; mean to SEM.

$C=$ controls $(n=7)$

$0=$ occluded group; survivors $(n=10)$ and non-survivors $(n=7)$. 

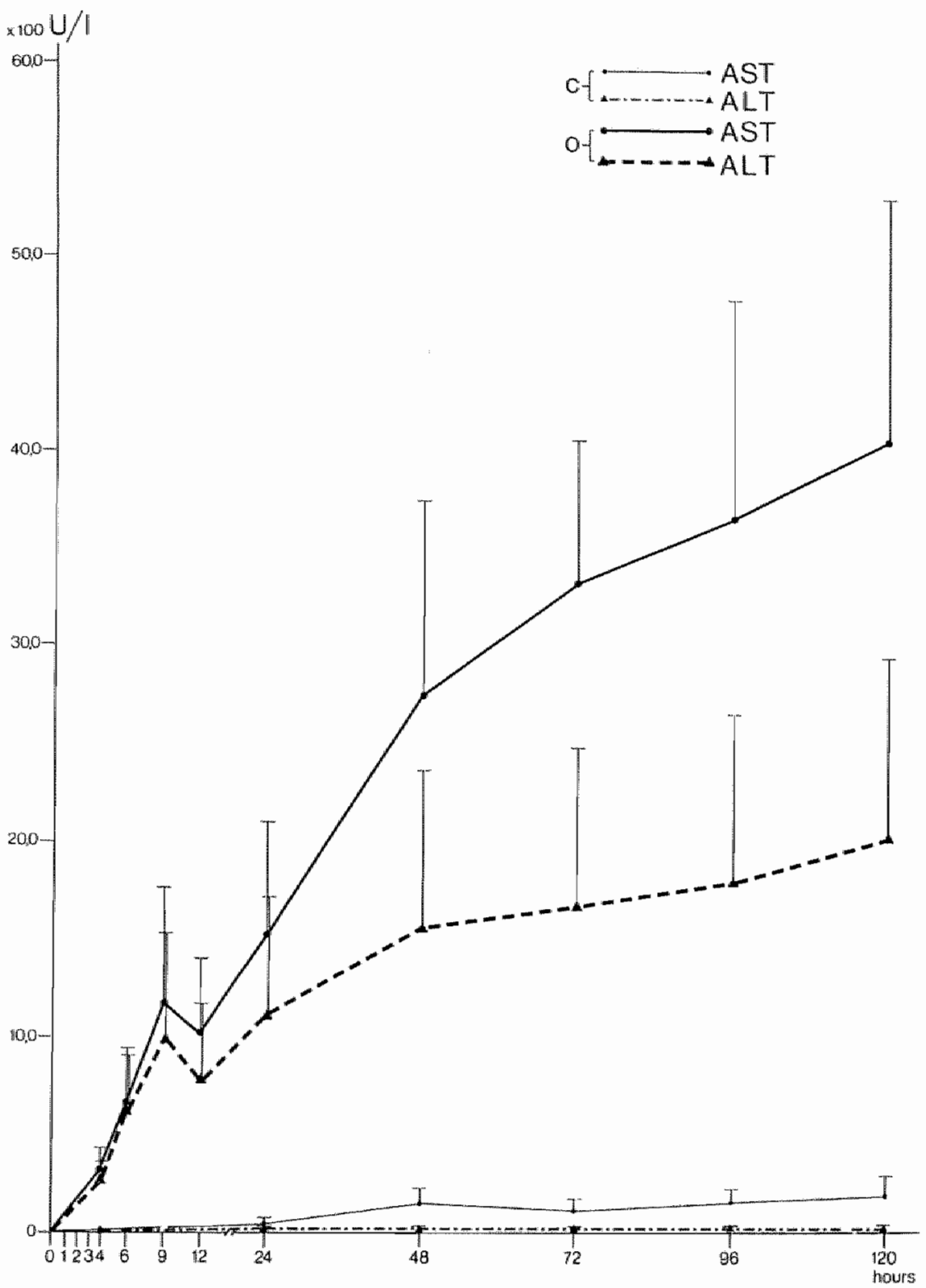

Fig. 6.2-4: Cumulative release of ALT and AST in U/L, mean $\pm S E M$.

$\mathrm{C}=$ controls $(\mathrm{n}=7)$

$\mathrm{O}=$ occluded group; surviwors $(\mathrm{n}=10)$ and non-survivors $(\mathrm{n}=7)$. 


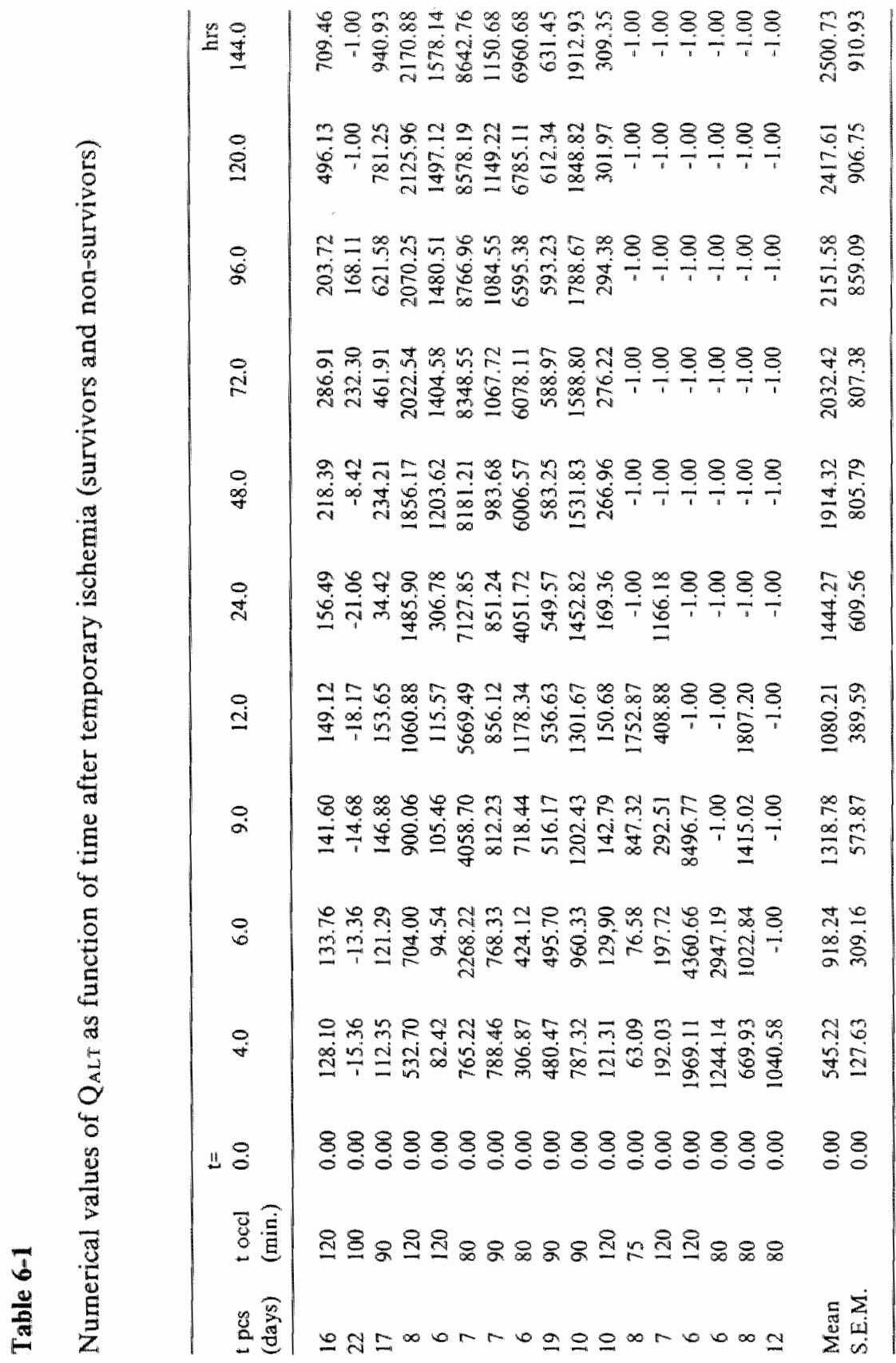




\subsection{Pathological aspects of acute hepatic ischemia}

A marked difference in behavior in the survivors and non-survivors between 9 and 24 hours after occlusion was noted. In the former group most dogs recovered within 9 to 12 hours while in that time most dogs in the latter group developed deep irreversible coma. After the occlusion only a few of the ultimately non-surviving dogs awakened for a short time. They were never able to stand up or to walk in their cages. Only when water was offered they managed to drink a little. Lethargy developed gradually in several hours. The animals often bumped into objects, swaying from side to side. Catatonic behavior became manifest with increasing drowsiness. Twitching of the neck and limbs appeared, together with negative responses to visual and auditory stimuli.

As is described by Edgcomb (1984) diversion of portal flow results in morphologic liver changes which are demonstrable with lightmicroscopy. However, these changes are more marked 3 to 6 weeks postoperatively. During this interval the hepatocytes exhibit reduction in size, an eosinophilic cytoplasm and a decrease in glycogen content. The nuclei of the hepatocytes are more abundant, many cells contain two or more nuclei. More interesting were the electronmicroscopic findings. A marked depletion of glycogen was visualized, while the mitochondria were abundant and more variable in size. The fat-storing cells and endothelial cells seemed unaffected, while the Kuppfer cells emerged larger. Edgcomb demonstrated despite portacaval shunting an increase in functional activity of the Kuppfer cells and a more marked resistance of these cells to deprivation of portal blood than hepatic parenchymal cells. In the literature such marked changes after 6 to 7 days are not reported. In our study, occlusion was performed one week after the portalsystemic shunt and the devascularization procedure, and biopsies were taken within 24 hours after occlusion. The effect of the temporary ischemia was followed in survivors, which were biopsied 2,4 and 6 weeks later. All biopsies showed similar histological features within 24 hours after occlusion. Normal liver tissue was only preserved in the periportal area, whereas extensive necrosis was observed in Rappaport zone 3 (fig. 6.3-1). Two weeks after recovery, multiple ceroid pigmentladen macrophages were demonstrated in areas of liver cell decay (fig. 6.3-2). Extensive macrovacuolar steatosis especially around the terminal veins was evident after 6 weeks. In the region of the portal triads unaffected liver tissue remained (fig. 6.3-3).

Swenson (1967) observed in sections which were studied with light microscopy mainly vascular lesions. In his study dogs underwent occlusion of the hepatic artery after performing a portafemoral shunt with a silicone 


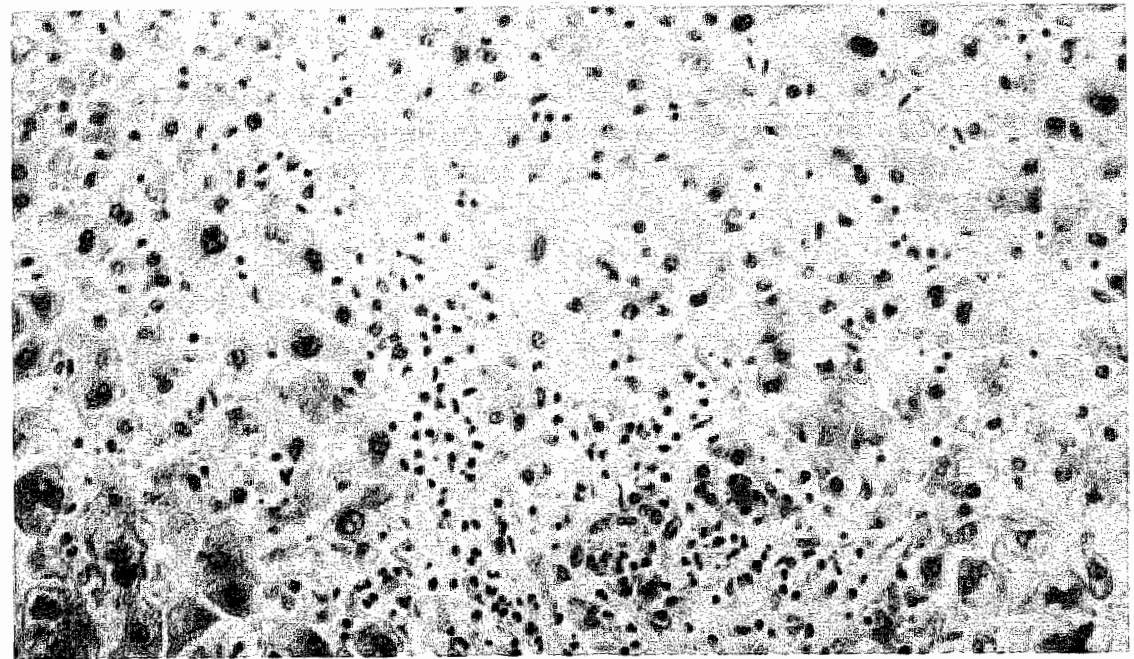

Fig. 6.3-1: Liver biopsy 24 h after occlusion. Note extensive centrilobular necrosis $(\mathrm{H}+\mathrm{E}$, medium power)

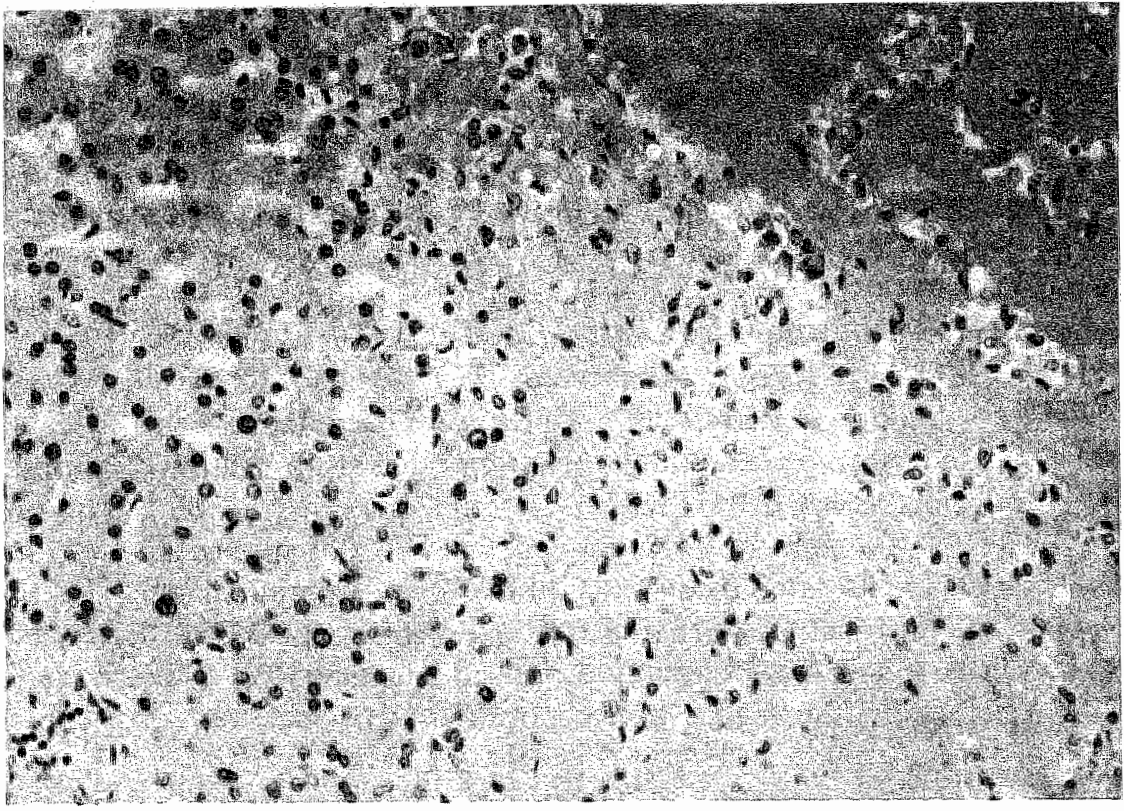

Fig. 6.3-2: Liver biopsy, two weeks after occhusion. Note predominantly mononuclear infiltrate with many macrophages and scarcity of hepatocytes ( $\mathrm{H}+\mathrm{E}$, medium power) 


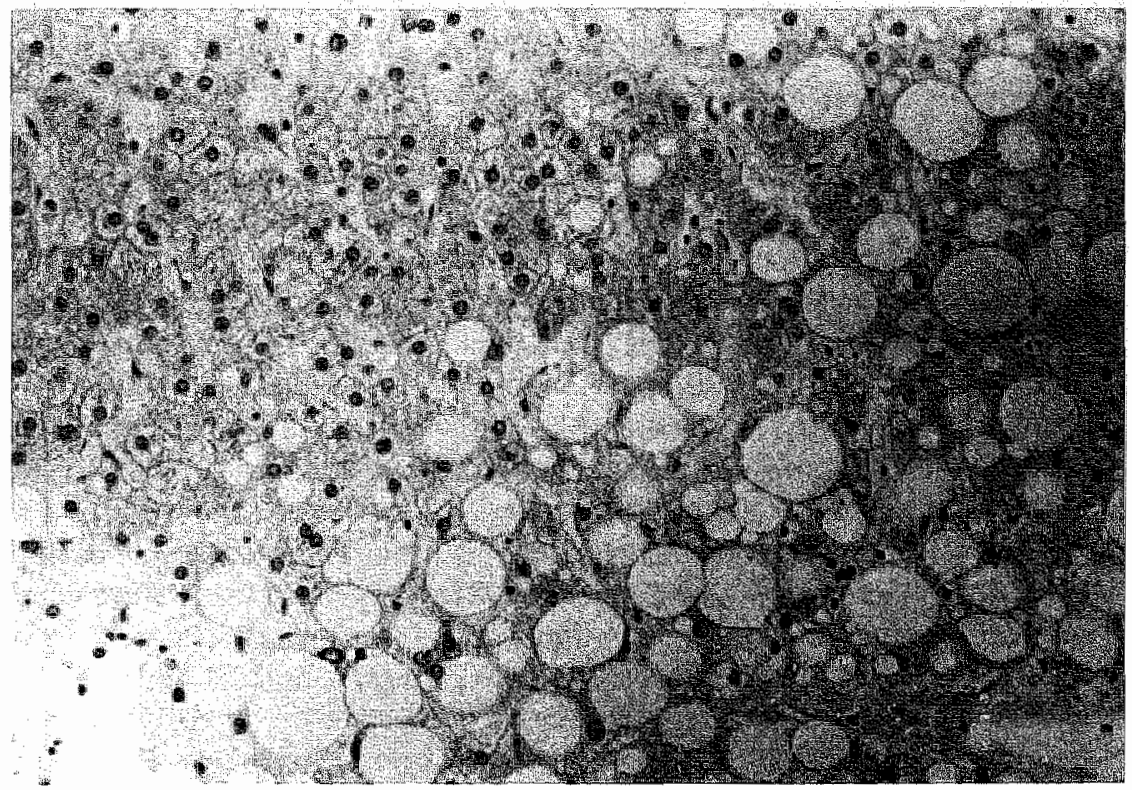

Fig. 6.3-3: Liver biopsy, 6 weeks after acclusion. Note extensive macrovacuolar steatosis around the central vein and relatively normal parenchyma in the portal area. $(\mathrm{H}+\mathrm{E}$, medium power)

tube. Initially, infiltration of the area around the terminal veins by polymorphonuclear leukocytes was observed, together with hepatic cell necrosis. Fatty infiltration of the same area was noted early and persisted. In the study of Misra (1972) with fully conscious dogs with graded periods of total ischemia, the dominant histopathological picture was a patchy hepatic necrosis, most marked at the periphery of the acinus, while the periportal zones demonstrated viable-looking cells. The walls of the central vein showed fibrinoid changes. Some liver cells adjacent to the portal tracts manifested fatty infiltration. In clamping studies in pigs, which had a portal decompression by an external splenojugular bypass procedure, Nordlinger (1980) observed initially cytoplasmatic microvacuolization being respon sible for a spongious appearance of the hepatic cells. After prolonged ischemia important cytoplasmatic condensation and nuclear pycnosis were noted, with some necrosis of hepatic cells. At time of death the liver appeared peliotic with massive necrosis. Inflammatory cells predominated around biliary canaliculi, where epithelial cells were desquamated. 


\subsection{Discussion}

The pattern of release of $\mathrm{CK}$ resembles the release of $\mathrm{CK}$ from damaged skeletal muscle in patients after cardiac surgery (Willems, 1985a and 1985b). In Chapter 7 it is shown that this is not the case during acute hepatic artery occlusion, but an indirect effect of hepatic necrosis on catabolism of $\mathrm{CK}$, developing some hours after occlusion, can not be ruled out. Howewer, this explanation is rather improbable because the postocclusion elevation of plasma CK activities is also observed in cases with negligible release of ALT, i.e. in the absence of substantial liver necrosis. Another explanation is suggested by the observation that straining of skeletal muscle may result in a disproportionally large rellease of CK if it is performed after previous muscle trauma. A large release of CK was observed, for instance, during moderate training of athletes some days after participation in a marathon running contest (Janssen, 1984). This build-up phenomenon in skeletal muscle damage suggests that part of the muscle cells were only reversibly damaged during devascularization surgery, but may release CK after relatively mild additional trauma.

The release of AST is surprisingly large compared to the release of ALT, even in the survivors. With the same assay conditions as used in the present study, the AST and ALT content of canine liver are respectively $112 \pm$ $14 \mathrm{U} / \mathrm{g}$ and $89 \pm 10 \mathrm{U} / \mathrm{g}$ (Visser, 1981a), expressed as mean ( \pm S.D.) activities per gram of wet weight. About $54 \%$ of total hepatic AST activity consists of mitochondrial AST (Visser, 1981a) and this mAST is usually only marginally released in plasma after liver injury. This leaves about $52 \mathrm{U} / \mathrm{g}$ of cytoplasmic AST (cAST) as releasable AST activity and the ratio of cumulative release $Q_{\mathrm{AST}} / \mathrm{Q}_{\mathrm{ALT}}$ should therefore be approximately $52 / 89=0.6$. If $\mathrm{QAST}_{\mathrm{AST}}$ and $\mathrm{Q}_{\mathrm{ALT}}$ are however calculated for the dogs in figure $6.2-2$, using values of $\mathrm{FCR}_{\mathrm{AST}}=0.21 \mathrm{~h}^{-1}$ and $\mathrm{FCR}_{\mathrm{ALT}}=0.022 \mathrm{~h}^{-1}$ (Hermens, 1982), a mean value of $1.7 \pm 0.9$ is found for $Q_{A S T} / Q_{A L T}$ in the non-survivors and $1.0 \pm 0.2$ for the survivors, in the period between 3 and 12 hours after occlusion. This implies that at least 2 times more AST is released than expected from global cytoplasmic enzyme content of the liver.

In order to explain this discrepancy the hypothesis was tested that more mAST is released as a result of additional mitochondrial damage due to reperfusion after temporary ischemia. This hypothesis is suggested by the observation that reperfusion of ischemic myocardium may lead to massive destruction of mitochondria (Hearse, 1977). The liver content of gluta mate dehydrogenase (GLDH), a mitochondrial enzyme, is $160 \pm 20 \mathrm{U} / \mathrm{g}$ (Visser, 
unpublished results) and the release of GLDH could therefore double the release of ALT if total mitochondrial enzyme content was released.

The activities of mAST, determined by column chromatography as explained in the methods, also never exceeded $10 \%$ of total AST activities in this period. Accordingly, there is no evidence for massive release of mitochondrial enzymes after temporary liver ischemia.

Another explanation for the disproportionally large release of AST is liver cell inhomogeneity. It has been noted, for instance, that patients with congestive liver damage due to cardiac failure showed much higher plasma activities of GLDH than patients with hepatitis (Guder, 1975). This finding was associated with a higher GLDH content of the central part of the liver lobule, compared to the periportal zone, and the occurrence of central lobular necrosis in such patients. In order to test this possibility one should study the necrotic liver at the cellular level and correlate the results to the enzyme content of fractionated liver cells. This program was clearly beyond the scope of the present study.

Disproportionate release of enzymes and disparities between survivors and non-survivors as shown in figure 6.2-2, could also indicate that the release of enzymes by the hepatocyte is not an all-or-none phenomenon. The cell could, at least temporarily, retain part of its contents and this process could preferentially influence the release of different enzymes, according to the nature of injury.

This question is closely related to the fundamental question whether the release of enzymes by the hepatocyte indicates irreversible damage or not. Studies aiming at answering this question have been hampered by the large capacity for regeneration of the liver which makes it impossible to measure cumulative necrosis during some length of time. There is an abundance of conflicting results on this matter in the literature. Studies claiming that hepatic damage can be detected histologically before elevations of enzyme activity occur in plasma, are contradicted by studies demonstrating elevated plasma enzyme activities without detectable irreversible injury to the liver (v. Dieijen-Visser, 1981 and Delacroix, 1984). In reviews on this matter (Schmidt, 1967 and 1968) it was concluded that increased plasma activities, as seen in acute liver disease, are accompanied by cellular infiltration and increased fractions of connective tissue in the liver, while exacerbations of enzyme release during chronic liver disease are interpreted as 'necrotic attacks'.

The mechanisms mentioned in the preceding section as possible explanations for a ratio of approximately unity during the first 12 hours after occlusion, need only be temporarily operative. Inhomogeneous necrosis or preferential release of enzymes only occurs during the first 48 hours 
after occlusion and after that time, the ratio of cumulatively released AST and ALT conform to the global liver content of these enzymes. A second aspect evident from table $6-1$ and figure $6.2-4$ is the large variation in the degree of damage, even in dogs occluded for the same period of time. 


\section{Liver damage as a potential source of error in the estimation of myocardial infarct size from plasma creatine kinase activity}

\subsection{Introduction}

Creatine kinase (CK) is often used as a marker enzyme for the detection and quantification of myocardial damage in clinical and experimental situations. Due to the high myocardial CK content, less than one gram of lost myocardium can be detected in plasma and, combined with CKMB, high sensitivity and specificity can be obtained.

The quantitative interpretation of plasma $\mathrm{CK}$ levels is, however, complicated by the rapid elimination of CK from plasma. If significant changes in the rate of $\mathrm{CK}$ elimination should occur, for instance as a result of liver congestion after acute myocardial infarction (AMI), a considerable error could be introduced in quantitive estimates of $C K$ release.

This potential hazard seemed less acute after the demonstration of Roberts (1975) that a number of hemodynamic perturbations in the dog such as reduction of cardiac output by constriction of the inferior vena cava, or subtotal occlusion of the hepatic artery, do not influence the elimination rate of CK from plasma. It was concluded that the liver is not involved in this elimination process. Recently however, Carlson (1982) directly estimated hepatic extraction of $C K$ in plasma and concluded that the liver is the main organ responsible for the elimination of $\mathrm{CK}$.

An obvious way to settle this controversy would be the measurement of CK elimination during complete blockade of hepatic blood supply. However, this cannot be performed straightforwardly because ligation of the portal vein results in immediate visceral congestion and profound shock.

The present study was undertaken to verify if liver damage normally occurs in patients after acute myocardial infarction. In addition, the effect of complete arrest of hepatic blood supply on the rate of elimination of CK from plasma could be measured in the dog after preliminary partial devascularization of the liver.

\subsection{Materials and methods}

Plasma enzyme activities were determined in patients with acute myocardial 
infarction admitted to the coronary care unit of the Academic Hospital Leiden. Patients with cardiogenic shock or manifest heart failure were not included in the study. Immediately after admission an intravenous catheter was installed and blood samples were obtained every $4 \mathrm{~h}$ until 48 hours after first symptoms, then every 8 h until 72 hours, every 12 h until 120 hours and every 24 hours until 240 hours (Witteveen, 1975). Mongrel dogs of both sexes $(20-40 \mathrm{~kg})$ were premedicated with fluanisone $(10 \mathrm{mg} / \mathrm{kg}$ ) and fentanyl citrate $(0.32 \mathrm{mg} / \mathrm{kg})$. Anesthesia was introduced with sodium pentobarbital $(10 \mathrm{mg} / \mathrm{kg})$ and, after endotracheal intubation, maintained with nitrous oxide in oxygen. An end-to-side portacaval shunt was installed and the vessels in the gastrohepatic ligament as well as the hepatic branches of the phrenic arteries were ligated. In order to prevent retrograde perfusion, the gastroduodenal artery was ligated distal from the last proper hepatic artery. The right gastric artery was carefully inspected because in about $30 \%$ of cases this artery did not bifurcate from the gastroduodenal artery but from a proper hepatic artery (cf. fig. 2.2-2). In those cases, the right gastric artery was also ligated. Two inflatable balloon occluders were placed around the common hepatic artery and the attachments were kept in a subcutaneous pocket.

After a single post-operative dose of $500 \mathrm{mg}$ ampicillin i.v., dogs were allowed to recover for 6-26 days and hepatic artery occlusions were performed in anesthetized dogs. Anesthesia was introduced with sodium pentobarbital $(10 \mathrm{mg} / \mathrm{kg})$ and after intubation maintained with intermittent fentanyl i.v. and oxygen monitored by blood pressure, pulse rate, expiratory $\mathrm{CO}_{2}$ concentrations and blood gas analysis (see chapter 3.4). This anesthetic procedure, without premedication, was chosen in order to minimize hemodynamic disturbances (as described in chapter 3.3). After a period of hepatic ischemia ranging from 60-120 minutes, ischemic liver damage was estimated from ALT activities measured in plasma samples taken $1,2,3,4,6,9,12,24,48,72,96,120$ and 144 hours after occlusion. For the determination of the disappearance rate of CK from plasma, a CK preparation was obtained by hypoxic incubation of dog heart in plasma (Visser, 1981a). After occlusion, bolus injections of $5-10 \mathrm{ml}$ of this preparation were given in the foreleg vein and thereafter blood samples of $4 \mathrm{ml}$ were obtained from a catheter in the femoral artery at $5,15,30,45,60$ and 90 minutes. Clotting was prevented with $5 \mathrm{U} / \mathrm{ml}$ heparin. Blood samples were immediately centrifugated for 10 minutes at $1000 \mathrm{~g}$. The supernatant plasma was made platelet-free by subsequent centrifugation at $30.000 \mathrm{~g}$ for 20 minutes. Thereafter samples were stored at $-70^{\circ} \mathrm{C}$. Untill determination of enzyme activities. Creatine kinase (CK, EC 2.7.3.2), alpha-hydroxybutyrate dehydrogenase (HBD, EC 1.1.1.27) and alanine aminotransferase 
(ALT, EC 2.6.1.2.) were assayed spectrofotometrically at $25^{\circ} \mathrm{C}$. using commercial testkits. Enzyme activities are expressed in micromoles of substrate converted per minute per litre of plasma (U/L). These values were determined in biopsies as described by van der Laarse (1980) and are expressed per gram of wet weight of tissue. Under these conditions, values of $856 \pm 86 \mathrm{U} / \mathrm{g}, 123 \pm 12 \mathrm{U} / \mathrm{g}$ and $5.1 \pm 1.5 \mathrm{U} / \mathrm{g}$ (mean \pm SD) are obtained for respectively the $\mathrm{CK}, \mathrm{HBD}$ and $\mathrm{ALT}$ content of human myocardium. The ALT content of dog liver is $89 \pm 10 \mathrm{U} / \mathrm{g}$ (Visser 1981b). The fractional catabolic rate constant of $\mathrm{CK}\left(\mathrm{FCR}_{\mathrm{CK}}\right)$, i.e. the fraction eliminated from plasma per hour, was determined from plots of the logarithm of $\overline{\mathrm{C}}(\mathrm{t})$ as a function of time $t$, where $\overline{\mathrm{C}}(\mathrm{t})$ is the plasma $C K$ activity at time $t, C(t)$, corrected for the normal steady state plasma acitivity $C_{s}$, i.e. $\bar{C}(t)=C(t)-C_{s}$. Values of $C_{s}$ were obtained from plasma samples taken before injection of $\mathrm{CK}$. This procedure assumes that the distribution space of CK can be approximated by the plasma volume (one-compartment model) as has been demonstrated by Visser (1981a). In that case, FCR $\mathrm{CK}_{\mathrm{K}}$ is simply the slope of the straight line fitted to the plot of $\ln \bar{C}(t)$ versus time. Plasma volumes were estimated from dilution of injected CK (Visser, 1982).

\subsection{Results}

Mean plasma enzyme activities and cumulative release of enzymes in patients after AMI are shown in fig. 7.3-1. Cumulative release is expressed in gram-equivalents of myocardium per litre of plasma, i.e. values of $Q$ (t) as callculated from Equations (1) and (2) were divided by the enzyme content of one gram of myocardium (see chapter 3.7). It is apparent from this figure that release of ALT can be fully explained by myocardial damage up to approximately 48 hours after AMI. Thereafter, extra release of ALT occurs. This is also demonstrated in fig. 7.3-2 which shows a good correlation between $Q_{H B D}(48)$ and $Q_{A L T}(48)$ whereas no correllation is apparent between release of ALT after 48 hours and total release of HBD. It should be noted that extra release of ALT of the magnitude as shown in fig. 7.3-1 indicates only minor liver damage because human liver contains about 8 times more ALT than human heart (Hermens 1982). Table 71 presents data on 10 dogs that underwent devascularization surgery and subsequent hepatic artery occlusion. One dog did not recover after installment of the portacaval shunt and is not included in this Table. Dogs Dl-D5 were used as controls to verify a possible direct effect of hepatic artery acclusion on plasma CK activity. Dogs D6-D10 were used for the

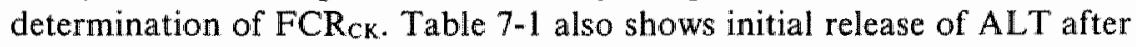




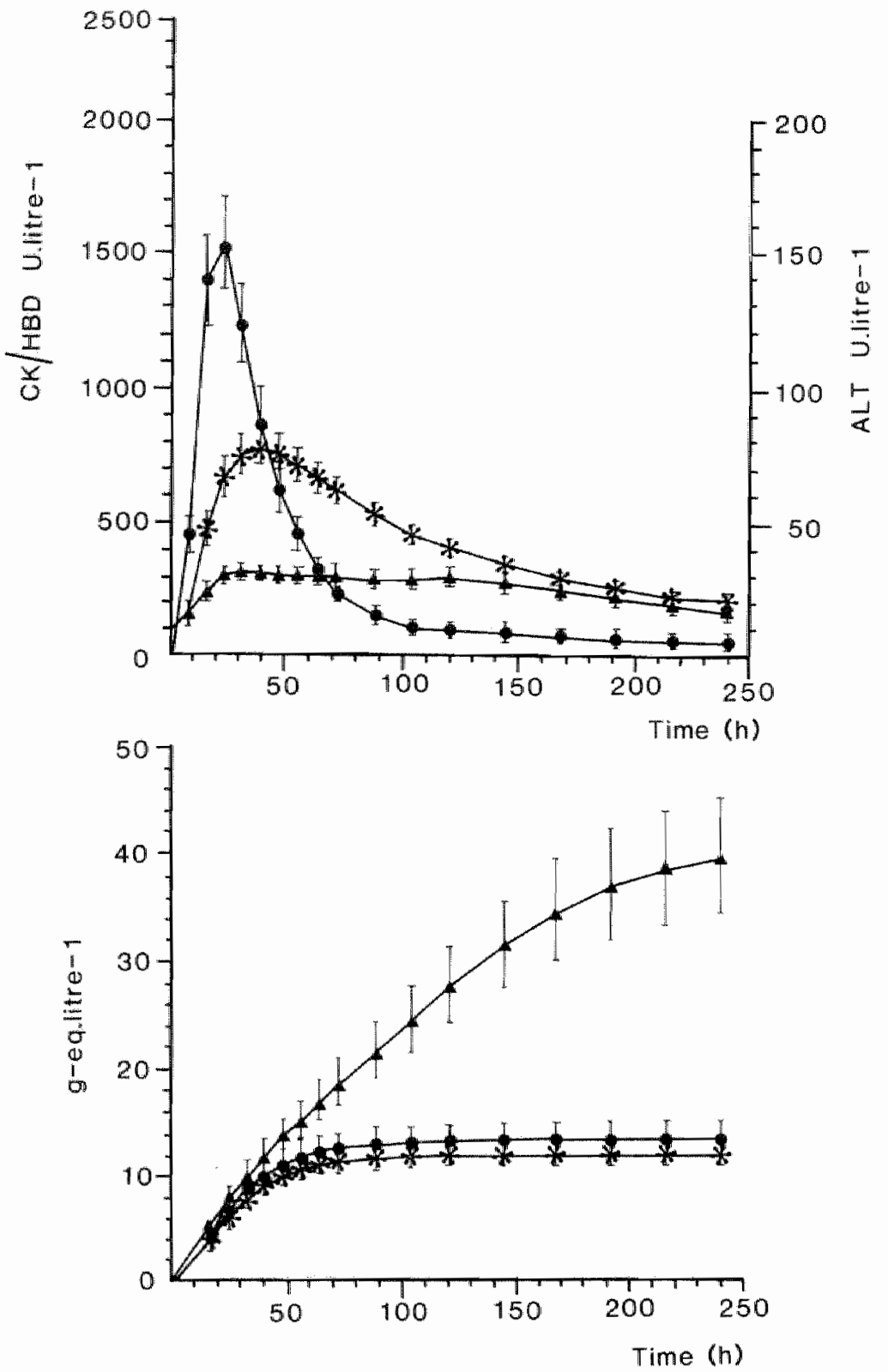

Fig. 7.3-1: Mean plasma activities (upper panel) and cumulative release expressed in gramequivalents of mycoardium (lower panel) of CK (*), HBD (*) and ALT (A) in 17 patients after AMI. Bars indicate SE. 

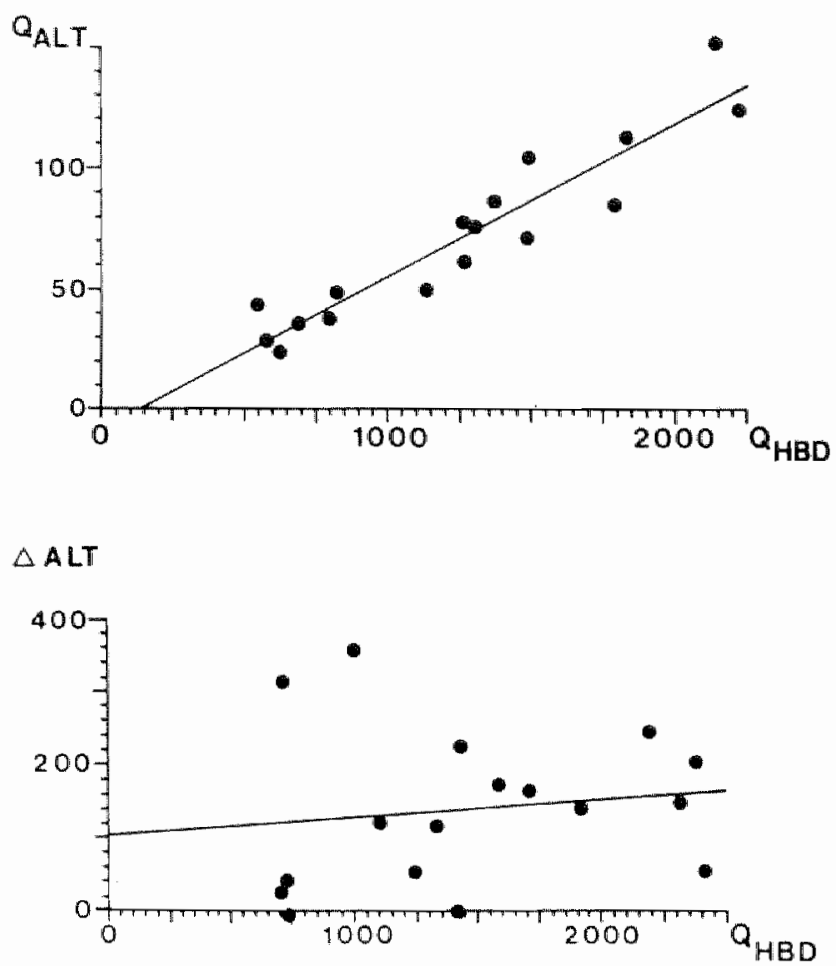

Fig. 7.3-2: Release of ALT and HBD during the first 48 h after AML (upper panel, $r=$ 0.94 ) and release of ALT between 48 and $240 \mathrm{~h}$ ( $\triangle$ ALT) as a function of totall release of HBD during $240 \mathrm{~h}$ (lower panel. $\mathrm{t}=0.12$ ).

hepatic artery occlusion. Two dogs, DI and D 10, showing a large release of A LT already during the first 4 hours after occlusion died soon afterwards in hepatic coma. One more dog, D4, with a somewhat slower but also considerable release of ALT died after 14 hours. It is also apparent that ischemic damage remained small in dogs D2, D5, D7 and D9, although for instance in D2 ischemia lasted for 2 hours. These data indicate large individual differences in the ischemic tolerance of the liver. This is also confirmed by the large individual variation in fig. 7.3-3. It follows from this Figure that leakage of enzymes from the liver mainly occurred during the first 48 hours after occlusion. 


\section{Table 7-1}

Response to hepatic ischemia in dogs

\begin{tabular}{|c|c|c|c|c|c|c|}
\hline \multirow{2}{*}{ Dog } & \multirow{2}{*}{$\begin{array}{l}\text { period with } \\
\text { portacaval } \\
\text { shunt (days) }\end{array}$} & \multirow{2}{*}{$\begin{array}{c}\text { period of } \\
\text { hepatic artery } \\
\text { occlusion (min) }\end{array}$} & \multicolumn{4}{|c|}{$Q_{A L I}(t)(U / D)$} \\
\hline & & & $t=4 h$ & $\mathrm{t}=6 \mathrm{~h}$ & $t=10 \mathrm{~h}$ & $t=144 \mathrm{~h}$ \\
\hline DI & 6 & 80 & 1073 & 2775 & died & - \\
\hline $\mathrm{D} 2$ & 7 & 120 & 152 & 131 & 188 & 473 \\
\hline D3 & 6 & 80 & 161 & 277 & 722 & 6773 \\
\hline D4 & 26 & 80 & 291 & 642 & 1164 & died \\
\hline D5 & 16 & 70 & 8 & 76 & 127 & 389 \\
\hline Do & 10 & 90 & 109 & 106 & 270 & 2265 \\
\hline D? & 19 & 90 & 57 & 71 & 99 & 170 \\
\hline D8 & 10 & 90 & 758 & 931 & 1225 & 1849 \\
\hline D9 & 10 & 50 & 103 & 111 & 126 & 252 \\
\hline DIO & 12 & 70 & 708 & died & - & - \\
\hline
\end{tabular}

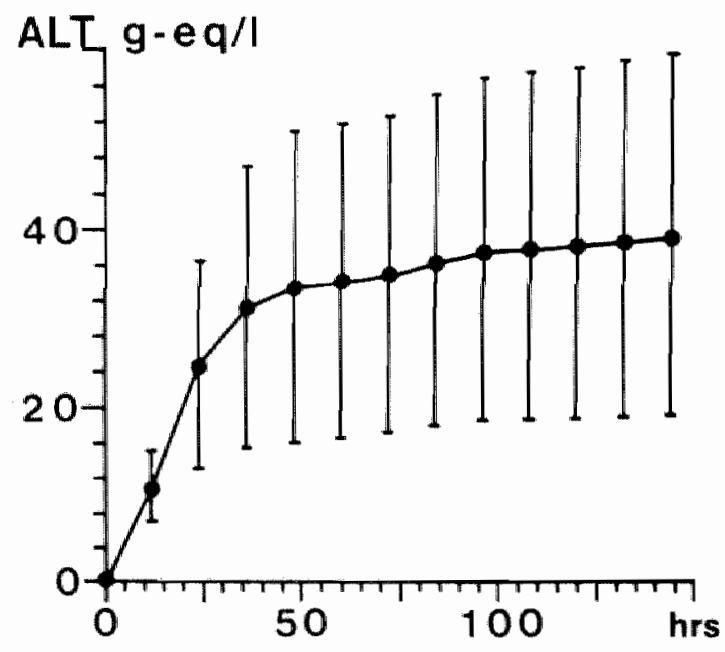

Fig. 7.3-3: Mean cumulative release of ALT, expressed in gram-equivalents of liver, in seven dogs surviving after hepatic artery occlusion. Bars indicate SE. 


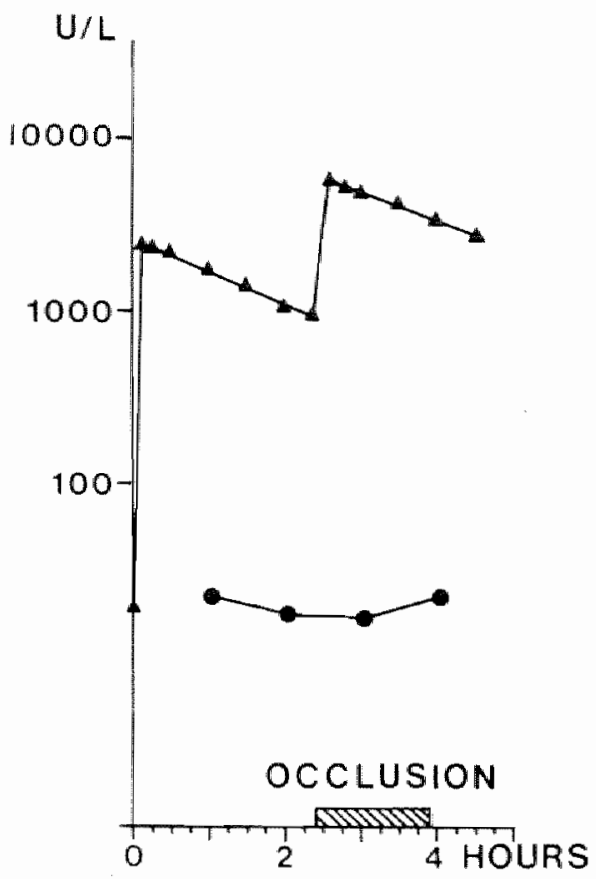

Fig. 7.3-4: Plasma $C K$ activities after repeated bolus injections of $C K$ before and after hepatic artery occlusion in dog D6. Plasma CK activities in control dog Dil are also shown.

Values of FCR $\mathrm{FK}_{\mathrm{K}}$ and plasma volume $\mathrm{V}_{\mathrm{p}}$ were determined twice in dogs D6-D 10. A first time during anesthesia, just before occlusion of the hepatic artery, and a second time during occlusion. Figure 7.3-4 shows an example of plasma $\mathrm{CK}$ activities due to these repeated $\mathrm{CK}$ injections. As also shown in this figure, the occlusion did not have a direct effect on plasma CK activities. Table 7-2 presents values obtained for FCR $\mathrm{FK}_{\mathrm{K}}$ and $\mathrm{V}_{\mathrm{p}}$, compared to control values determined in healthy dogs with the same CK preparation. The slightly reduced value of plasma volume in D7-D10 indicates that the portacaval shunt did not cause a significant degree of venous pooling. It is also apparent from table 7-2 that anesthesia combined with the preliminary partial devascularization of the liver had no effect on FCR CK. $_{\text {. }}$ The subsequent complete blockade of hepatic blood supply also did not cause a significant reduction of $F_{C R}$ and it appears that the liver is not involved to any significant degree in the elimination of $\mathrm{CK}$ from plasma. 


\section{Table 7-2}

Effect of hemodynamic interventions on the fractional catabolic rate constant of $\mathrm{CK}$ and on plasma volume

\begin{tabular}{|c|c|c|c|c|}
\hline \multirow[t]{2}{*}{ dog } & \multicolumn{2}{|c|}{$\begin{array}{l}\text { portacaval shunt without } \\
\text { hepatic artery occlusion }\end{array}$} & \multicolumn{2}{|c|}{$\begin{array}{l}\text { portocaval shunt with } \\
\text { hepatic artery occlusion }\end{array}$} \\
\hline & $\operatorname{FCR}\left(\mathrm{h}^{-1}\right)$ & $V_{p}(\mathrm{ml} / \mathrm{kg})$ & $\mathrm{ECR}\left(\mathrm{h}^{-1}\right)$ & $\mathrm{V}_{\mathrm{p}}(\mathrm{ml} / \mathrm{kg})$ \\
\hline D6 & 0.36 & 50 & 0.34 & 43 \\
\hline $\mathrm{D} 7$ & 0.21 & 41 & 0.25 & 33 \\
\hline $\mathbb{D E}$ & 0.34 & 38 & 0.28 & 38 \\
\hline 09 & 0.23 & 53 & 0.21 & 43 \\
\hline D10 & 0.44 & 38 & 0.27 & 42 \\
\hline McantsEM & $0.32 \pm 0.04$ & $44 \pm 3$ & $0.27 \pm 0.02$ & $40 \pm 2$ \\
\hline
\end{tabular}

\subsection{Discussion}

Erhardt (1974) has demonstrated a correlation of $\mathrm{r}=0,79$ between myocardial infarct size, determined by staining of heart slices with nitrobluetetrazolium, and maximal plasma activity of thermostable lactate dehydrogenase (LDH) in 43 patients who died after AMI. This correlation was found irrespectively of liver damage, defined by plasma ALT activities

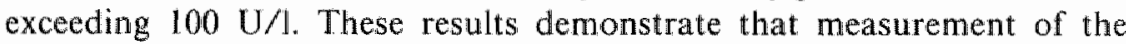
thermostable isoenzymes of $\mathrm{LDH}, \mathrm{LDH}_{1}$ and $\mathrm{LDH}_{2}$, permits estimation of myocardial infarct size even in cases of severe heart failure. The HBD assay used in the present study is based on the preferential capacity of $\mathrm{LDH}_{1}$ and $\mathrm{LDH}_{2}$, compared to the other isoenzymes of $\mathrm{LDH}$, to catalyse the conversion of alpha-ketobutyrate to alpha-hydroxybutyrate. This assay therefore measures the same activity as is determined in the thermostable LDH assay.

Several studies have also validated the use of cumulative release of $\mathrm{CK}$ or CK-MB for the estimation of myocardial infarct size (Bleifeld 1977 , Grande 1982 and Reimer 1983). These results are confirmed by the parallel 
course of cumulative release of $\mathrm{HBD}$ and $\mathrm{CK}$ in fig. $7.3 \mathrm{-1}$ and support the use of these curves for estimation of myocardial necrosis.

Liver cell necrosis as a result of heart failure is well known and has been associated with right heart failure (Sherlock 1951, White 1955 and Killip 1960). In uncomplicated infarction, plasma activities of ALT usually do not exceed the normal upper level (West 1966). This is confirmed in the present study by the mean maximal activity of about $30 \mathrm{U} / \mathrm{l}$ (cf. fig. 7.3-1). It is interesting to note that these moderate ALT elevations still accurately reflect myocardial damage during the first 48 hours after AMI as shown by the high correlation in fig. 7.3-2.

Further release of ALT in the absence of release of CK and HBD, as shown in fig. 7.3-1 after 48 hours, is highly specific for liver damage (Schmidt 1979). This strongly supports the conclusion that some liver damage occurs secondary to AMI, even in uncomplicated cases. This hepatic involvement only becomes manifest in the third day after AMI and is not related to infarct size as shown in the lower panel of fig. 7.3-2.

Hepatic blood supply is effected predominantly by the portal vein and the hepatic artery provides only about $30 \%$ of total inflow (Richardson 1981). Significant additional supply may occur through the hepatic branches of the phrenic arteries, the small arteries in the gastrohepatic ligament and by retrograde flow through the gastroduodenal artery. Occlusion of the portal vein in the dog results in prompt portal congestion and shock. In experimental studies this complication is either prevented by the use of intestinal ischemia or, as in the present study, by providing a shunt pathway for the portal blood. These intricacies of hepatic blood supply were not always appreciated but also in studies taking full account of them, a marked variation in the tolerance of individual dogs to hepatic ischemia has been noted (Popper, 1954; Jolly, 1963; Farkouh, 1971). Apparently some ill-understood, probably metabolic, factors are of major influence on liver cell necrosis after ischemia.

Estimated values of FCR CK $_{\text {in }}$ the dog range from $0.29 \mathrm{~h}^{-1}$ to $0.39 \mathrm{~h}^{-1}$ and in man from $0.12 \mathrm{~h}^{-1}$ to $0.20 \mathrm{~h}^{-1}$ (Rapaport, 1975; Roberts, 1977; Dawson, 1969; Tommassini, 1979; Visser, 1981a; Willems, 1982).

This high value of $F C R_{C K}$, compared for instance to a value of $F C R_{H B D}$ $=0.015 \mathrm{~h}^{-1}$ in man, implies that the eliminated quantity of enzyme, i.e. the last term in Equation (1), soon becomes dominant in calculations of cumulative release of CK (Dawson, 1969; Willems, 1979) (see chapter 3.7). In practical applications cumulative release of $\mathrm{CK}$ is calculated by using a fixed mean value for $\mathrm{FCR}_{\mathrm{CK}}$ and large individual variations in this parameter, due to different degrees of impaired liver function, would cause large errors in such calculations. 
Indirect evidence against the occurrence of such errors is provided by the validations just mentioned. More directly, it was shown that a $70 \%$ reduction of the blood flow in the common hepatic artery only resulted in a temporary reduction of the disappearance rate of $\mathrm{CK}$ from plasma. This effect was attributed to visceral release of $C K$ because the normal disappearance rate was resumed within 100 minutes (Roberts 1975). However, this intervention does not cause major liver ischemia. Also, release of $\mathrm{CK}$ due to hepatic artery occlusion is not observed in the present study (cf. fig. 7.3-4). An alternative approach to assess the relation between liver function and the elimination of CK from plasma is suggested by the recently introduced technique of constant rate infusions of $\mathrm{CK}$ in the dog. If such infusions are maintained until plasma $C K$ levels have reached plateau values, model-independent estimates of FCR $\mathrm{CK}_{\mathrm{K}}$ are obtained by dividing the rate of CK infusion by the plateau CK activity in plasma (Visser, 1981a). Moreover, the absolute quantity of CK eliminated from plasma is largely increased by the high plasma CK activities during infusion, and this allows direct detection of a possible extraction of $\mathrm{CK}$ from blood passing through the liver. In a recent application of this technique, differences in CK activity were measured in blood samples taken from the carotid artery, the inferior vena cava and from the left hepatic vein (Carlson 1982). Total hepatic plasma flow was estimated in this study by different microspheres and it was concluded that hepatic extraction of CK could account for the total elimination of $\mathrm{CK}$ from plasma. This result completely contrasts with the present study demonstrating that elimination of the liver from the circulation has no effect on FCR $\mathrm{CK}_{\mathrm{K}}$. A possible explanation for the discrepancy with Carlson (1982) is suggested by the high value of $708 \mathrm{ml} / \mathrm{h}$ quoted for the plasma clearance of $\mathrm{CK}$ by this author. Taking the mean body weight of $17 \mathrm{~kg}$ quoted in this study, a value of $42 \mathrm{ml} / \mathrm{kg} / \mathrm{h}$ is obtained. For a plasma volume of $51 \mathrm{ml} / \mathrm{kg}$ (cf. Table 7-2) this implies a value of $F_{C R}=42 / 51=0.82 \mathrm{~h}^{-1}$ which is more than twice the normal value (cf. Table 7-2). Such a high value suggests that the purified CK preparation used in this study contained a partially denatured labile fraction. It is well known that such fractions are indeed rapidly cleared by the liver (Hermens 1982).

Information about the sites and mechanism of the degradation of circulating tissue enzymes is surprisingly scarce. Several authors have shown that hemodynamic disturbances in the dog, such as nephrectomy (Dunn, 1958), splenectomy (Fleischer, 1963) or constriction of the vena cava (Roberts, 1975), have no influence on the plasma disappearance rates of aspartate aminotransferase (AST), ALT or CK. This was also demonstrated after hepatectomy for LDH and isocitric dehydrogenase (Strandjord, 1959). 
However, perioperative injury and the rapidly deteriorating animal condition make such experiments difficult to interpret (Sibley, 1958). Intravenous injection of zymosan, a polysaccharide from yeast cell membranes, caused a marked reduction in the disappearance rate of A.ST (Wakim, 1963a), and CK (Roberts, 1975). As zymosan also inhibits the plasma clearance of colloidal carbon (India ink), which is mainly effected by uptake in the Kupffer cells in the liver, this observation suggests hepatic elimination of enzymes. However, inhibition of the uptake capacity of the Kupfer cells by a previous injection of India ink did not influence the disappearance of AST. Also, release of AST and LDH in plasma was observed after administration of zymosan which could explain the observed reduction in the disappearance rates (Wakim, 1963b). Apparently, many questions remain unsettled but the present study indicates that the liver is only marginally involved in the elimination of CK from plasma. 


\section{Summary and conclusions}

In the introductory chapter of this thesis the rationale for performing the studies described in this thesis is given.

Acute hepatic ischemia has been the subject of many studies. Differences in study design and animal models have diminished the reproducibility of the results and have made interpretation of the data obtained difficult. Furthermore in most studies, no endeavour was made to quantitate liver injury.

Therefore the aim of this study was to establish a model of acute liver ischemia in the dog. To quantitate liver injury metabolic, enzymatic and morphologic sequelae of liver ischemia were studied. In addition metabolic and enzymatic parameters were studied with regard to their ability to distinguish at an early stage dogs that were going to die from acute liver ischemia from dogs that would survive.

In chapter 2 the literature is reviewed concerning the arterial blood supply to the liver. It is well documented that there is a great variability in the subhepatic arterial blood supply. It is less well known that suprahepatic arterial branches supply the liver, which are often forgotten in devascularization studies of the liver. Similarly it is not always appreciated that the proper hepatic arteries are no end arteries so that occlusion of the common hepatic artery or the celiac axis does not result in total interruption of the arterial bloodflow to the liver. Retrograde flow may occur from the gastroduodenal artery which is an arcadian artery receiving blood both from the celiac axis and from the superior mesenteric artery, and from the right gastric artery when it branches off from one of the proper hepatic arteries. This retrograde flow may promote survival after devascularization procedures of the liver. In chapter 4 retrograde flow is quantitated by means of injection of radioactive microspheres. It was demonstrated that if no great care was taken to interrupt the gastroduodenal artery and right gastric artery during the devascularization procedure, substantial residual arterial inflow to the liver remained. Similarly in surviving dogs the development of collateral flow after devascularization could be studied. The interval between performing the portacaval shunt / devascularization 
and occlusion of the arterial inflow is crucial in this respect. An interval of not more than a week should be observed to prevent interferences because of the development of collateral circulation.

In chapter 3 , the outline of the definitive protocol is described. The choice of anesthesia proved to be essential to ensure that anesthesia would not interfere with catecholamine-, insulin- and glucagon levels. A combination of fentanyl and oxygen was administered. Repeated intravenous dosages guaranteed reliable measurements of these hormones.

In chapter 5 the value was studied of sequential measurement of metabolic parameters before, during and after occlusion with regard to their ability to quantitate at an early stage the severity of ischemic injury and ultimately to indicate which dogs would die and which would survive.

For that purpose intermediates of glucose-, fat- and protein metabolism were measured in plasma, simultaneously with insulin, glucagon, epinephrine and norepinephrine. In a pilot study the hepatic artery was occluded for 60 minutes. Progressive increases in plasma glucagon, normal insulin levels but no hypoglycemia were found. In the definitive experiment an occlusion time of 120 minutes was employed. This resulted in moderate hypoglycemia coinciding with progressive increases in plasma glucagon and normal insulin levels.

After revascularization the liver appears to be able to maintain adequate glucose levels when high glucagon levels are present. This pattern was found both in surviving and in non-surviving dogs although in the nonsurvivors mean glucose levels were lower than in survivors albeit not significantly. In recent literature the clearance rate for amino acids is introduced (A-fV/A) and employed to estimate clearance of amino acids by the splanchnic tissue and specifically the liver. Especially the clearance rate of alanine was significantly higher in surviving dogs than in nonsurviving dogs. Because alanine is quantitatively by far the most important nitrogen containing precursor for gluconeogenesis in the liver, this may indicate that the capacity of the liver to synthesize glucose is substantially diminished in non-surviving dogs. Clearance rates of other (groups of) amino acids (total AA, GIn, AAA, other AA) exhibited a similar trend as alanine but differences between survivors and non-survivors were not significant. Several other parameters were evaluated that have been propagated in the past as potential indicators of the degree of liver failure and/or encephalopathy. The BCAA/AAA ratio, the ketone body ratio, ammonia levels and the lactate/pyruvate ratio were evaluated. No significant differences between survivors and non-survivors were found.

There is still no clarity in the literature, as to whether liver injury can be detected histologically at an earlier stage than by means of measurement 
of increased enzyme concentrations (chapter 6). To get an impression of the sequence of events occurring after occlusion of the hepatic artery liver biopsies were taken within $24 \mathrm{hr}$, and after 2,4 and 6 weeks. The release of ALT and AST was followed with the use of enzymatic quantitation employing a two compartment model. Histological changes occurred uniformly within $24 \mathrm{hr}$ after occlusion both in survivors and in nonsurvivors.

Massive necrosis occurred preferentially in zone 3 according to Rappaport. Recovery is characterized by some degree of fatty infiltration and relatively little regeneration. Within groups a considerable variability in the release of ALT and AST occurred. Not withstanding this, within 12 hrs after occlusion, considerably more AST was released in non-survivors than in survivors. Apparently the release of enzymes is not an 'all or none' phenomenon. The hepatocyte is able to, at least temporarily, retain part of its contents and this process could preferentially influence the release of different enzymes. In this respect the permeability of the hepatocyte and of the mitochondrial membrane needs further study.

In chapter 7 the model developed is employed to study the elimination of $\mathrm{CK}$ during acute liver ischemia. The use of the cumulative release of $\mathrm{CK}$ in combination with $\mathrm{CK}-\mathrm{MB}$ is an accepted method to estimate the size of a myocardial infarction. It is not completely elucidated, however, in how far the liver is responsible for the elimination of $\mathrm{CK}$ from plasma. It appeared from this study that elimination of CK continues during acute liver ischaemia. Because during complete occlusion we may assume that virtually no clearance can be effected by the liver, this implies that $\mathrm{CK}$ is cleared in other organs in the body. Measurements of the cumulative release of CK, HBD and ALT indicate that patients have, even after an uncomplicated myocardial infarction, on the third day still increased ALT activity. The quantity of ALT that can be released from cardiac muscle after an infarction, cannot explain this phenomenon, so that mild injury of the liver must be responsible for this. 


\section{Samenvatting en conclusies}

Er is weinig bekend over de preventie of behandeling van schade aan de lever door ischemie of shock. Leverfunctiestoornissen, al of niet gepaard gaande met morfologische afwijkingen, zoals deze worden waargenomen in een scala van ziektebeelden, worden dikwijls geassocieerd met een bepaalde mate van ischemie van de lever. Als gevolg van de hoge metabole activiteit van de levercel wordt deze door anoxie snel beschadigd. In studies naar de pathogenese van leverinsufficièntie als gevolg van ischemie wordt dierexperimenteel voornamelijk ófwel met technieken van geisoleerde leverperfusie gewerkt, dan wel met devascularisatieprocedures van de lever met of zonder aanleg van een portaalsystemische shunt. Uit al deze experimenten zijn veel gegevens vrijgekomen over de meest gebruikte diersoorten, echter de grote variabiliteit per species blijkt de reproduceerbaarheid van de gebruikte technieken niet ten goede te komen. De gedetailleerde beschrijving van een reproduceerbaar model van acute leverischemie bij de hond is een belangrijk streven van onze studie geweest. Dit model werd getoetst op de metabole en enzymatische consequenties veroorzaakt door de aangebrachte ischemische schade. Het aanleggen van een portaalsystemische shunt is bij een dergelijk model voorwaarde, omdat occlusie van de vena portae langer dan een half uur tot de dood leidt. Additionele gevolgen van de shunt zelf dienen dan eveneens beschouwd te worden.

Bij literatuurstudie van de arteriële bloedvoorziening van de lever bij de hond blijkt er een grote variabiliteit in de subhepatische regio te bestaan (hoofdstuk 2). De invloed van de suprahepatische takken naar de lever, de arteriae phrenicae, werd in occlusie-studies van de afferente vasculaire inflow van de lever vaak vergeten, ondanks het reeds in 1954 door Popper aangegeven belang van genoemde takken tijdens subhepatische arteriële occlusie. In de beschrijving van vele devascularisatieprocedures wordt deze suprahepatische arteriële voorziening van de lever niet vermeld. Naast deze laatstgenoemde arteriële bloedvoorziening bestaat nog een ander belangrijk fysiologisch fenomeen tijdens arteriële occlusie van de lever. Na occlusie 
van de arteria hepatica communis blijkt een aanzienlijke retrograde flow te bestaan vanuit de arteria gastroduodenalis en/of de arteria gastrica dextra. De grote variabiliteit van het verloop van de arteria gastrica dextra blijkt hierbij van essentieel belang. De retrograde flow bevordert de overleving van de hond na occlusie van de arteriële inflow gecombineerd. met een portaalsystemische shunt. Deze retrograde flow kon met behulp van de microspheertechniek bevestigd worden. Met behulp van deze techniek werd tevens gecontroleerd in welke mate de ischemie absoluut was en in welke mate er sprake moest zijn van een mogelijke ontstane collaterale flow (hoofdstuk 4). Van belang daarbij is de duur van het interval tussen het aanleggen van de portaalsystemische shunt en de werkelijke occlusie, aangezien bij een langer interval onvermijdelijk collateralen ontstaan. Een marge van één week tussen het aanleggen van een portacavale anastomose en de occlusie kon in dit verband worden aangehouden. $\mathrm{Na}$ diverse pilotstudies werd een protocol opgesteld voor de definitieve studie (hoofdstuk 3). De keuze van anesthesie bleek niet onbelangrijk met betrekking tot metingen van catecholaminen, insuline en glucagon. Een combinatie van fentanyl en zuurstof, intermitterend intraveneus toegediend, garandeerde betrouwbare metingen wan deze hormonen.

Sequentieel gemeten metabole parameters tijdens en na occlusie zouden unformatie kunnen verschaffen - separaat dan wel gecombineerd - wélke metabole parameters reeds in een vroeg stadium de ernst van de ischemische schade kunnen weergeven, en wélke parameters overleving of overlijden zouden kunnen aangeven. Daartoe werden intermediairen uit de glucose-, vet- en aminozuurstofwisseling gemeten, simultaan met insuline, glucagon, epinephrine en norepinephrine (hoofdstuk 5). In een pilotstudie waarbij de arteria hepatica gedurende 60 minuten werd geoccludeerd, kon geen hypoglycemie worden geconstateerd. Wel werd een progressief stijgende hyperglycagonemie bij een vrijwel constante normoinsulinemie gemeten. Bij een occlusieduur var 120 minuten ontwikkelde zich echter een lichte hypoglycemie bij progressief stijgende plasmawaarden van glucagon en normale plasmawaarden van insuline. Na rewascularisatie zijn lever en nier blijkbaar in staat in aanwezigheid van een persisterende hyperglucagonemie en normale insulinespiegels een adequaat glucosepeil te handhaven. Zowel in de groep van de overlevende als in de niet-overlevende groep honden werd dit patroon waargenomen, hoewel in de niet-overlevende groep gemiddeld lagere (niet significante) waarden werden gevonden.

In de recente literatuur is het begrip klaringsratio voor aminozuren geïntroduceerd. Hiermee kan, als flow naar de periferie bekend is en aannemende dat een steady state situatie bestaat, gemeten worden hoe groot de hoeveelheid aminozuren is die door het splanchnicus gebied wordt 
opgenomen. Een dergelijke meting is gebruikt als leverfunctietest. In deze studie kon niet beschikt worden over flowmetingen, zodat alleen de klaringsratio (A-fV/A) voor alle aminozuren samen en voor (groepen) aminozuren afzonderlijk gebruikt is als indicator van het vermogen van de lever aminozuren af te breken of om te zetten in eiwit. Het meest duidelijke verschil tussen overlevers en niet-overlevers werd gevonden voor alanine. De alanine klaringsratio nam bij overlevers toe, terwijl deze bij niet-overlevers afnam. Daar alanine de belangrijkste stikstofbevattende precursor is voor gluconeogenese in de lever, wijst dit er op dat het vermogen van de lever glucose te vormen bij niet-overlevers belangrijk verminderd is. Het gebruik van de alanine klaringsratio verdient derhalve ook in de kliniek onderzocht te worden. De klaringsratio's van andere aminozuren (totaal $A Z, G \mid n, A A Z$, andere $A Z$ ) vertoonden eenzelfde beeld als alanine, maar de verschillen tussen overlevers en niet-overlevers waren niet significant.

Verschillende andere parameters zijn in het verleden gepropageerd om de mate van leverfalen of de graad van encephalopathie aan te geven.

- De plasmaratio tussen vertakte keten aminozuren en aromatische aminozuren was gemiddeld lager in de niet overllevende honden maar uitsluitend ten gevolge van toename van de spiegels van aromatische aminozuren. Door de hoge standaarddeviaties konden deze parameters niet gebruikt worden om onderscheid te maken tussen honden die stierven en honden die overleefden.

- De ketonlichaamratio verschilde niet significant tussen overlevers en niet-overlevers.

- De opname van ammoniak over de extremiteiten was al voor occlusie groter in de niet-overlevers. Dit verschil was niet significant. Na occlusie traden geen wezenlijke verschillen op in veneus en arterieel bloed tussen overlevers en niet-overlevers.

- De lactaat/pyruvaat ratio was evenmin significant verschillend tussen de groepen.

Het is in de literatuur nog steeds niet duidelijk of leverschade eerder histologisch kan worden vastgesteld dan wel door middel van het vaststellen van verhoogde enzymconcentraties in plasma. Om hier een indruk van te krijgen werden leverbiopsieën genomen binnen 24 uur en na 2, 4 en 6 weken. Met behulp van enzymquantitering volgens het twee-compartimenten model werd het vrijkomen van ALT en AST vervolgd (hoofdstuk 6). De histologische afwijkingen binnen 24 uur na occlusie waren in de groep van overlevenden en de groep van niet-overlevenden éénduidig. Massale necrose trad op vooral in zone 3 volgens Rappaport. Herstel wordt gekarakteriseerd door vettige infiltratie, waarbij relatief weinig regeneratie 
werd gevonden. Binnen de groepen bestond een aanzienlijke variabiliteit in uitstorting van ALT en AST. Desalniettemin bleek in de twee groepen binnen de eerste twaalf uur na occlusie, een behoorlijke hoeveelheid AST meer te worden uitgestort in de niet-overlevenden dan in de overlevenden. De uitstorting van enzymen is blijkbaar niet een 'alles of niets' fenomeen. De levercel kan mogelijk, althans tijdelijk, een gedeelte van zijn inhoud vasthouden, waardoor het vrijkomen van enzymen wordt beïnvloed. De permeabiliteit van de hepatocyt en van de mitochondriale membraan verdient in dit kader verdere studie.

Het gebruik van de cumulatieve uitstorting van $\mathrm{CK}$ in combinatie met $\mathrm{CK}-\mathrm{MB}$ voor het schatten van de uitgebreidheid van een hartinfarct is een geaccepteerde methode. De mogelijkheid, dat de lever medeverantwoordelijk is voor de eliminatie van CK uit plasma, werd getoetst in een gecombineerde studie bij infarctpatienten en honden volgens het beschreven model. De lever blijkt slechts marginaal betrokken bij de eliminatie van $\mathrm{CK}$ uit plasma. Bij metingen van cumulatieve uitstorting van $\mathrm{CK}, \mathrm{HBD}$ en ALT blijkt dat patienten na een infarct, zelfs in ongecompliceerde gevallen, op de derde dag nog steeds verhoogde ALT-activiteit hebben. De hoeveelheid ALT die uit hartspierweefsel na een infarct vrij kan komen, kan dit niet verklaren, zodat milde leverschade hiervoor verantwoordelijk moet zijn. 


\section{References}

Aguirre, A., Yoshimura, N., Westman, T. and Fischer, J.E. (1974). Plasma amino acids in dogs with two experimental forms of liver damage. J. Surg. Res. 16: 339.

Alford, F.P., Dudley, F.J., Chisholm, D.J. and Findlay, D.M. (1979). Glucagon metabolism in normal subjects and in cirrhotic patients before and after portasystemic venous shunt surgery. Clin. Endocrinol. 11: 413

Alivisatos, D.N. and Filippakis, M. (1971). Quelques données expérimentales sur l'arrêt provisoire de la circulation affërente du foie. J. Chir. (Paris) 101: 191.

Bauer, W., Bale, H.H., Poulsson, I..T. and Richards, D.W. (1932). The control of circulation through the liver. J. Physiol. (London) 74: 343.

Bergmeijer, H.U. and Bernt, E. (1974). Manuelle U-V test Methode für Alanin-aminotransferase in Blut. In: Methoden der enzymatischen analyse, Band I and II, Bergmeijer, H.U. (ed.) Verlag Chemie, Weinheim, 769.

Bernal, R., Hutson, D.G., Dombro, R.S., Livingstone, A., Lewi, J.U. and Zeppa, R. (1982). A possible hepatic factor in the control of plasma free fatty acid levels. Metabolism 31: 533.

Bleifeld, W., Mathey, D., Hanrath, P., Buss, H. and Effert, S. (1977). lnfarct size estimated from serial serum creatine phosphokinase in relation to left ventricular hemodynamics. Circulation 55: 303 .

Boden, G., Rezvani, $\mathbb{l}$, and Owen, $O . \mathbb{E}$. (1984). Effects of glacagon on plasma amino acids. J. Clin. Invest. 73: 785 .

Boer de, J.E.G. (1984). Branched chain amino acid metabolism in portal systemic shunting. Thesis, Uniwersity of Limburg, Maastricht, The Netherlands.

Boer de, J.E.G., Oostenbroek, R.J., Dongen wan, J.J., Janssen, M.A., Soeters, P.B. (1986). Sequential metabollic characteristics following portacaval shunt in rats. Eur. Surg. Res. $18: 96$.

Bradley, E.L. (1974). Measurement of hepatic blood flow in man. Surgery 75: 783.

Brauer, R.W. (1963). Liver circulation and function. Physiol. Rev. 43: 115.

Brunschwig, A. (1955). Observations on the surgical physiology of the human liver pertinent to radical partial hepatectomy for neoplasm. Cancer $8: 459$.

Burchell, A.R., Moreno, A.H., Panke, W.F., Nealon, T.F. (1976). Hepatic artery flow improvement after portacaval shunt: a single hemodynamic clinical correlate. Ann. Surg. 184: 289.

Carlson, C.J., Meister W., Emilson, B., Sheiner, L.B. and Rapaport, E. (1982). Clearance of serum creatine kinase activity. Cardiovasc. Res, 16:66.

Castro de, J., Van de Water, A., Wouters, L., Xhonneux, R., Reneman, R. and Kay, B. (1979). Comparative study of cardiovascular, neurological and metabolic side-effects of eight narcotics in dogs. Acta Anaesth. Belg. 30: 5 .

Cherrington, A.D., Chasson, J.L., Liljenquist, J.E., Jennings, A.S., Keller, U. and Lacy, 
W.W. (1976). The role of insulin and glucagon in the regulation of basal glucose production in the postabsorptive dog. J. Clin. Invest. 58: 1407.

Cherrington, A.D. Lacy, W.W. and Chasson, J.-L. (1978). Effect of glucagon on glucose production during insulin deficiency in the dog. J. Clin. Invest. 62: 664.

Cherrington, A.D., Liljenquist, J.E., Shulman, G.I., Williams, P.E. and Lacy, W.W. (1979). Importance of hypoglycemia-induced glucose production during isolated glucagon deficiency. Ami. J. Physiol. 236: E263.

Cherrington, A.D., Williams, P.E., Shulman, G.I. and Lacy, W.W. (1981). Differential time course of glucagon's effect on glycogenolysis and gluconeogenesis in the conscious dog. Diabetes 30: 180 .

Clowes, G.H.A., Dermott, W.V., Willams, L.F., Loda, M., Menzoian J.O. and Pearl, R. (1984). Amino acid clearance and prognosis in surgical patients with cirrhosis. Surgery 96:675.

Clowes, G.H.A., Hirsch, E., George, B.C., Bigatelloa, L.M., Mazuski, J.E., Villee, C.A. (1985). Survival from sepsis. Ann. Surg. 202: 446.

Cooper, G.M., Paterson, J.L., Ward, I.D. and Hall, G.M. (1981). Fentanyl and the metabollic response to gastric surgery. Anaesthesia 36: 667.

Corbic, M. Lebrec, D., Dafniet Le, D. and Erlinger, S. (1984). A new method to measure portal and hepatic blood flow using taurocholate in the rat. Hepatology 4: 112 .

Crook. J.N., Paris, M.F. and Nance, F.C. (1970). Studies of hepatic blood flow and hepatic function after ligation of the hepatic artery and portal vein. Arm. Surgeon 36: 724 .

Czok, R, and Lamprecht, W. (1974). Enzymatische Bestimmung von Pyruvat. $\mathbb{m}$ : Methoden der enzymatischen Analyse, Band II, Bergmeijer, H.U. (ed.), Verlag Chemie, Weinheim, 1491.

Da Fonseca Wollheim, F., Bergmeijer, H.U and Gutman, J. (1974). Ammoniak. In: Methoden der enzymatischen analyse, Band $I$ and $I 1$, Bergmeijer, H.U. (ed.), Verlag Chemie, Weinheim, 1749.

Dawson, D.M., Alper, C.A., Seidman, I. and Mendelsohn, J. (1969). Measurement of serum turnover rates. Ann. Int. Med, 70: 799.

Delacroix, D.L., Courtoy, P.J., Rahier, J., Reynaert, M., Vaerman, J...P. and Dive, C. (1984). Localization and serum concentration of secretory component during massive necrosis. of human لiver. Gastroenterology 86:521.

Deutsche Geselsschaft fur klinische Chemie $(1970,1971,1972,1974)$. Optimierte StandardMethode Tur GLDH aktiviert. Z. Klin. Chem. und Klin. Biochem. 8: 658, 9: 464, 10 : 182 and $12: 391$ respectively.

Deysach, L.J. (1941). Nahure and loeation of 'sphincter mechanism' in the liver as determined by drug actions and vascular injections. Am. J. Physiol, 132: 713.

Dieifen van-Visser, M.P. (1981). Behaviour of tissue enzymes in the circulation. Thesis, University of Limburg, Mastricht, The Netherlands.

Dilley, K.I. and Rocek, P.H. (1979). In L.KB-protein chemistry notes 10 and 11 (LKB Biochrom Lid., Cambridge, England).

Dongen van, J.J., Maessen, J.M., Oostenbroek, R.J., Boer de, J.E.G., Kootstra, G. and Soeters, P.B. (1984). Portacaval shunts by means of suture and button. In: CRC Handbook of Microsurgery, vol. II, Olszewski, W.L. (Ed.), CRC press, Boca Raton, Flonida, 319.

Drapanas, T., Becker, D.R., Alfano, G.S., Potter, W.H. and Stewart, J.D. (1955). Some of the effects of interrupting hepatic blood flow. Ann. Surg. 142: 831 .

Duncombe, W.G. (1964). In vitro enzymatic colorimetric method for the quantitative determination of non-esterified (or free) fatty acids in serum. Clin. Chim. Acta 9: 122.

Dumn, M., Martins, J, and Reissman, K.R. (1958). The disappearance rate of glutamic 
oxalacetic transaminase from the circulation and its distribution in the body's fuid compartments and secretions. J. Lab. Clin. Med. SI: 259.

Duve de, D. (1959). Lysosomes, a new group of cytoplasmic particles, subcellular particles. Ed. Hyashi, T., Ronald Press Cy., New York, 128.

Edgcomb, L.P., Eckhauser, F.E., Porter-Fink, V.L., Knol, J.A. and Strodel, W.E. (1984). Effects of portacaval shunt and portacaval transposition on hepatoceliular and hepatic reticuloendothelial cell activity in the dog. J. Surg. Res. 36: 446.

Editorial (1979). High-dose fentanyl. Lancet 1: 81.

Editorial (1980). Fentanyl and the metabolic response to surgery. Br. J. Anaesth. 52: 561 .

Engel, G.L. and Vulto, A.G. (1983). De bepaling van Catecholaminen in plasma (1). Chemisch Magazine, sept. 1983, 388

Erhardt, L.R. (1974). Clinical and pathological observations in different types of acute myocardial infarction. Acta Med. Scand. (Suppl.) 560: 1.

Farkouh, E.F., Daniel, A.M. and MacLean, L.D. (1971). The effect of collateral circulation on survival in liver ischemia. J. Surg. Res. 11:130.

Federspil, G., Boninsegna, A., Picchi, G., Zanon, G. and De Palo, C. (1980). Effect of portacaval shunt on circulating free fatty acids and ketonebodies in rats. Metabolism 29: 495 .

Felig, P. (1973). The glucose-allanine cycle. Metabolism 22: 179.

Fischer, J.E., Rosen, H.M., Ebeid, A.M., James, J.H., Keane, J.M. and Soeters, P.B. (1976). The effect of normalization of plasma amino acids on hepatic encephalopathy. Surgery 80: 77 .

Fitts, W.T., Scott, R. and Mackie, J.A. (1950). Antibiotics in the prevention of death following ligation of the hepatic artery in dogs. Surgery 28: 458 .

Fleisher, G.A. and Wakim, K.G. (1963). The fate of enzymes in body fluids - an experimental study I. J. Lab. Clin. Med. 61: 76.

Gelman, S.I. (1976). Disturbances in hepatic blood how during anesthesia and surgery. Arch. Sarg. 111: 881 .

Goodall, R.G.W., Hyndman, W.W.B. and Gurd, F.N. (1957). Studies on hypothermia in abdominal surgery. Arch. Surg. 75: 1011.

Gouma, D.J., Coelho, J.C.U., Schlegel, J., Fisher, J.D., Li, Y.F. and Moody, F.G. (1986). Estimation of hepatic blood now by hydrogen gas clearance. Surgery 99: 439.

Grande, P, Hansen, B.F., Christiansen, C. and Naestoft, J. (1982). Estimation of acute myocardial infarct size in man by serum CK-MB measurements. Circulation $65: 756$.

Grävenstein, H. (1938). Uber die Arterien des grossen Netzes beim Hunde. Morph. Jahrb. 82: 1 .

Greenway, C.V. and Stark, R.D. (1971). Hepatic wascular bed. Physiol. Rev. 51: 23.

Groot de, G.H. (1984). Studies on acute hepatic insufficiency. "Thesis, Erasmus University, Rotterdam, The Netherlands.

Guder, W.G., Habicht, A., Kleissl, J., Schmidt, U. and Wieland, D.H. (1975). The diagnostic significance of liver cell inhomogeneity: serum enzymes in patients with central liver mecrosis and the distribution of glutamate dehydrogenase in nomal human liver. $Z$. Klin. Chem. Klin. Biochem. 13:311

Gurll, N.J., Reynolds, D.G., Coon, D. and Shirazi, S.S. (1980). Acute and chronic splanchnic blood flow responses to portacaval shunt in the normal dog. Gastroenterology $78: 1432$.

Haberer, H. (1906). Experimentelle Unterbindung der Leberarterie. Arch. Klin. Chir. 78: 557.

Hall, G.M., Young, C., Holdcroft, A. and Alaghband-Zadeh, J. (1978). Substrate mobilization during surgery. Anaesthesia 33: 924. 
Hasselgren, P.O., Almersjö, O., Gustavsson, B. and Seeman, T. (1979). Amino acid incorporation into liver proteins during short-term ligation of the hepatic artery in the dog. Eur. Surg. Res. 1 1l: 366.

Hearse, D.J. (1977). Reperfusion of the ischemic myocardium. I. Mol. Cell. Cardiol. 9: 605.

Hermens, W.T. Willems, G.M. and Visser, M.P. (1982). Quantification of circulating proteins. The Hague, Martinus Nijhoff-Kluwer, Boston, Hingham, Mass.

Hines, J.R. and Roncoroni ${ }_{*}$ M. (1956). Acute hepatic ischemia in dogs. Surg. Gynecol. Obstet 102: 689 .

Hollenberg, M. and Dougherty, J. (1966). Liver blood flow measured by portal venous and hepatic arterial routes with Kr-85. Am. J. Physiol. 210 (5): 926.

Huggins, C., Carter, E.L, and McDermott, W.V. (1957). Differential hypothermia in experimental hepatic surgery. Arch. Surg 74: 327.

Huguet, C., Nordlinger, B., Bloch, P. and Conard, J. (1978). Tolerance of the human liver to prolonged normothermic ischemia. Arch. Surg. 113: 1448.

Imler, M., Schlienger, J.L., Frick, A., Stahl, A., Chabier, G. (1982). Study of muscular glutarnine and alanine release in cirrhotics with hyperammonemia and in ammonium infused rats. In: Aminosäuren und Ammoniak Stoffwechsel bei Leberinsufficienz, Holm, E. (ed.), Verlag Gerhard, Witzstrock, Baden-Baden, Köln, New York, 33.

Janssen, E., Kuipers, H., Keizer, H. and Verstappen, F. (1984) Plasma enzyme activities and running performance in a maximal treadmill test before and after a $30 \mathrm{~km}$ race or a marathon. Int. J. Sports Med. 5 (suppl.): 98.

Jennings, A.S., Cherrington, A.D., Liljenquist, J.E., Keller, U., Lacy, W.W., Chiassan, J.L. (1977). The roles of insulin and glucagon in the regulation of gluconeogenesis in the postabsorptive dog. Diabetes 26: 847.

Jeppsson, B., Dahl, E.P., Fredlund, P.E., Stenram, U. and Bengmark, S. (1979). Hepatic necrosis in the pig produced by transient arterial occlusion. Eur. Surg. Res. 11:243.

Johnstone, F.R.C. (1957). Acute ligation of the portal vein. Surgery 41: 958.

Jolly, P.C. and Foster, J.H. (1963). Hepatic inflow stasis. Surgery 54: 45.

Kabadi, U.M., Eisenstein, A.B., Tucci, J. and Pellicone, J. (1984). Hyperglucagonemia in hepatic cirrhosis: its relation to hepatocellular dysfunction and normalization on recovery. Am. J. Gastroenterol. 79: 143.

Karmen, A. (1955). A note on the spectrophotometric assay of glutamic-oxaloacetic transaminase in human blood serum. J. Clin. Invest. 34: 131 .

Keller, U., Sonnenberg, G.E., Burckhardt, D. and Perruchoud, A. (1982). Evidence for an augmented glucagon dependence of hepatic glucose production in cirrhosis of the liver. J. Clin. Endocrinol. Metab. 54: 961 .

Kerr, J.C., Reynolds, D.G. and Swan, K.G. (1975). Hemodynamics of experimental portal wenous occlusion in dogs. Am. Surgeon 41: 198.

Killip, T. and Payne, M.A. (1960), High serum transaminase activity in heart disease. Circulatory failure and hepatic necrosis. Circulation 21: 646.

Knisely, M.H., Harding, F, and Debacker, H. (1957). Hepatic sphincters. Science 125: 1023.

Kock, N.G., Hahnloser, P., Roding, B. and Schenk Ir., W.G. (1972). Interaction between portal venous and hepatic arterial flow: an experimental study in the dog. Surgery 72 : 414.

Latarse van der, A., Dijkshoorn, N.J., Hollaar, L. and Caspers, T. (1980). The (iso-) enzyme activities of lactate dehydrogenase, alpha-hydroxybutyrate dehydrogenase, creatine kinase and aspartate aninotransferase in human myocardial biopsies and atutopsies. Clin. Chim. Acta 104: 381 . 
Lampe, E.W., Moberg, A.W., Simnons, R.L. and Najarian, J.S. (1971) Impairnent of glueose homeostasis after hepatic ischemia. J. Surg. Res. 11:224.

Lautt, W.W. (1977). Hepatic vasculature: a conceptual review. Gastroenterology 73: 1163.

Lefebve, P. and Luyckx, A. (1979). Glucagon. In: Hormones in blood, C.H. Gray and V.H.T. James (Eds.), Academic Press, 171.

Leiberman, D.P., Mathie, R.T., Harper, A.M. and Blumgart, L.H. (1978). The hepatic arterial and portal venous circulation of the liver studied with a Krypton-85 clearance technique. J. Surg. Res. 25: 154.

Lewis, F. and Wangensteen, O.H. (1950). Penicillin in the treatment of peritonitis due to liver autolysis in dogs. Proc. Soc. Exp. Biol. Med. 73; 533.

Lindberg, B.O. And Clowes, G.H.A. (1981). An experimental method for situdy of liver blood flow and metabolism in intact animals. J. Surg. Res. $31: 156$.

Longmire, W.P. and Marable, S.A. (1961). Clinical experiences with major hepatic resections. Anm. Surg. 154: 460.

Mackenzie, R.J., Furnival, C.M., O'Keane, M.A and Blumgart, L.H. (1975). The effect of hepatic ischaemia on liver function and the restoration of liver mass after 70 per cent partial hepatectomy in the dog. Br. J. Surg. 62: 431.

Mackenzie, R.J., Furnival, C.M., Wood, C.B., O'Keane, M.A. and Blumgart, L.H. (1977). The effects of prolonged hepatic ischaemia before 70 per cent partial hepatectomy in the dog. Br. J. Surg. 64: 66 .

Marco, J., Diego, J., Villanueva, M.L., Diaz-Fierros, M., Valverde, I and Segovia, I.M. (1973). Elevated plasma glucagon levels in cirrhosis of the liver. N. Engl. J. Med. 289: 1107 .

Markowitz, J. (1949). Experimental surgery of the liwer. In: Experimental Surgery. Willams and Wilkins Corp., Baltimore.

Mathie, R.T., Lam, P.H.M., Harper, A.M. and Blumgart, L.H. (1980). The hepatic arterial blood flow response to portal vein occlusion in the dog. Pflügers. Archiv. 386: 77.

Maynard Beach, P., Torres, E., Litton, A. and Kundsin, R. (1965). Acute occlusion of the portal vein in dogs. Surg. Gynecol. Obstet. 121, 761.

McDonald, T.J., Dupre, J., Caussignac, Y., Radziuk, J. and Van Vhiet, S. (1979). Hyperglucagonemia in liwer cirmosis with portal-systemic venous anastomoses: responses of plasma glucagon and gastric inhibitory polypeptide to oral or intravenous glucose in cirrhotics with normal or elevated fasting plasma ghucose levels. Metabolism 28: 300.

Mellanby, J. and Williamson, D.H. (1974). Acetacetaat. In: Methoden der enzymatischen analyse, Band II, Bergmeijer, H.U. (ed.), Verlag Chermie, Weinbeim, 1887.

Miller, M.E. Christensen, G.C. and Evans, H.E. (1964). The heart and arteries, chapter 4. In: Anatomy of the dog, Saunders Comp., Philadelphia, Londion.

Miller, D.J., Hickman, R., Fratter, R., Terblanche, J. and Saunders, S.J. (1976). An animal model of fulminant hepatic failure: a feasibility stady. Gastroenterology $7 \mathbb{1}: 109$.

Misra, M.K., P"eng, F.K., Sayhoum, A., Kashii, A., Derry, C.D., Caridis, 'T. and Slapak, M. (1972). Acute hepatic coma: a canine model. Surg. Gynecol. Obstet. 72: 634 ,

Moreno, A.H., Rousselot, L.M., Burchell, A.R., Bono, R.F. and Burke, J.H. (1962). Studies on the outflow tracts of the liver. II. On the outflow tracts of the canine liver with particular reference to its regulation by the hepatic vein sphincter mechanisms. Ann. Surg. 155: 427.

Neill, S.A., Gaisford, W.D. and Zuidema, G.D. (1963). A comparative anatomic study of the hepatic veins in the dog, monkey and human. Surg. Gynecol. Obstet. 116:451.

Nordlinger, B., Douwia, D., Javaudin, L., Bloch, P., Aranda, A., Boschat, M. and Huguet, C. (1980). An experimental study of survival after two hours of normothermic hepatic 
Isichemia. Surg. Gynecoll. Obstet. 1 Ju: ony.

Mosadini, R, Avogaro, A, Mollo, F., Marescott, C., Tiengo, A., Duner, E., Merkel, C.。 Gatta, A., Zuin, R., De Kreutzenberg, S., Trevisan, R. and Crepaldi, G. (1984). Car" bohydrate and lipid metabolism in cirrhosis. Evidence that hepatic uptake of gluconeogenic precursiors and of free fatty acids depends on effective hepatic flow. J. Clin. Endocrinol. Metab. 58: 11.25 .

Nxumalo, J.L., Teranata, M. and Schenk, W. (1978). Hepatic blood flow measurement. Total hepatic blood flow measured by ICG clearance and electromagnetic flowmeters in a canine septic shock model. Ann. Surg. 187: 299.

Ohkubo, T. (1979). Effects of anesthesia and surgery on carbohydrate metabolism and endocrine function including glucagon in man. Jap. J. Anesth. 28: 1062.

Onnis, M., Shumacker, H.B. and Bounous, G. (1962). Response to occlusion of the portal vein. Arch. Surg. 85: 89 ?.

Oostenbroek, R.J., Boer de, J.E.G., Eyk van, H. Wesdorp, R.I.C. and Soeters, P.B. (1982). Normal plasma amino acids, insulin and glucagon levels of frequently used tat models. J.P.E.N. 6: 30 .

Oostenbroek, R.J., Willems, G.M., Boumans, M.L.L., Soeters, P.B. and Hermens, W.T. (1985a). Leverfunctie en creatinekinase-eliminatie in plasma. Ned. Tijdschr. Geneeskd. 129: 569 .

Oostenbroek, R.J., Willems, G.M., Boumans, M.L.L., Soeters, P.B. and Hermens, W.T. (1985b). Liver damage as a potential source of error in the estimation of myocardial infarct size from plasma creatine kinase activity. Cardiovasc. Res. 19:113.

Ozawa, K., Kamiyama, Y., Kimura, K., Yamamoto, M., Aoyama, H., Yasuda, K. and Tobe, T. (1983). Contribution of the arterial blood ketone body ratio to elevate plasma amino acids in hepatic encephallopathy of surgical patients. Am. J. Surg. 146: 299.

Park, C.R and Exton, J.H. (1972). Glucagon and the metabolism of glucose. In: Glucagon, P.J. Lefebvre and R.H. Unger (Eds.), Pergamon Press, 77.

Payer, J., Riedel, J., Minar, J. and Moravec, R. (1956). Der extrahepatale Abschnitt der Leberarterie des Hundes wom Gesichtspunkt der chirurgischen Anatomie. Anat. Anz. 103: 246.

Popper, H.L., Jefferson, N.C. and Necheles, H. (1953). Interruption of hepatic artery and portal ligation of portal vein. Am. J. Surg. 86: 309.

Popper, H.L., Jefferson, N.C. and Necheles, H. (1954). Survival of dogs after partial or total devascularization of the liver. Ann. Surg. 140: 93

Prinzen, F.W., Vusse van der, G.J. and Reneman, R.S. (1981). Blood flow distribution in the left ventricular wall in open-chest dogs. Basic Res. Cardiol. 76: 431.

Racine, Ph., Klenk, H.-O. and Kochsiek, K. (1975). Rapid lactate determination with an electrochemical enzymatic sensor: clinical usibility and comparitive measurements. Z. Klin. Chem. Klin. Biochem. 13:533.

Raffuce, F.L. and Wangensteen, O.H. (1951). Tolerance of dogs to ocelusion of entire afferent vascular inflow to the liver. Surg. Forum 1: 191.

Rapaport, E. (1975). The fractional disappearance rate of the separate isoenzymes of creatine phosphokinase in the dog. Cardiovasc. Res. 9: 473.

Rappaport, A.M. (1973). Liwer architecture and microcirculation. In: Alcoholic Liver Pathology, Khanna, J.M. Israel, J. and Kalant, H. (Eds.), Addiction Research Foundation, Ontario, 43.

Reimer, K.A., Hackel, D.B., Ideker, R.E., Mikat, E.M., Hartwell, T.D., Parker, C.B., Braunwald, E.B., Gold, H.K., Raabe, D.S., Rude, R.E., Sobel, B.E., Stone, P.H. and Roberts, R. (1983). Comparison of enzymatic and anatomic estimates of myocardial infarct 
size in man. Clin. Res. 31: 214A.

Restrepo, J.E, Warren, W.D. (1962). Total liver blood flow after portacaval shunts, hepatic artery ligation and 70 per cent hepatectomy. Ann. Surg. 156: 719.

Richardson, P.D.I. and Withrington, P.G. (1981). Liver blood flow. Gastroenterology 81 : 159.

Robert, J.-J., Bier, D.M., Zhao, X.H., Matthews, D.E. and Young, V.R. (1982). Glucose and insulin effects on de nowo amino acid symthesis in young men: studies with stable isotope labeled alanine, glycine, leucine and lysine. Metabolism 31: 1210.

Roberts, R., Henry, P.D., Sobel, B.E. (1975). An improved basis for enzymatic estimation of infarct size. Circulation $52: 743$.

Roberts, R. and Sobel, B.E. (1977). Effect of selected drugs and myocardial infarction on the disappearance of creatine kinase from the circulation in conscious dogs. Cardiovasc. Res. 11: 103.

Sampson, E.J., Miller, A.S. and McKneally, S.S. (1978). Columnchromatographic separation of isoenzymes of aspartate aminotransferase. Clin. Chem 24: 1805 .

Schmidt, E. Schmidt, F.W. and Otto, P. (1967). Isoenzymes of malic dehydrogenase, glutamic oxaloacetic transaminase and lactate dehydrogenase in serum in diseases of the liwer. Clin. Chim. Acta 15: 283.

Schmidt, E. (1968). Enzym-Austritt. In: Praktische Enzymologie, Schmidt, F.W. and Huber, H. (Eds.), Hans Huber Verlag, Bern, 93.

Schmidt, E., Schmidt, F.W., Trautschold, I. and Friedel, R. (1979). In: Advances in clinical enzymology. Karger, Basel, 239.

Sebel, P.S., Bovill, J.G., Schellekens, A.P.M. and Hawker, C.D. (1981). Hormonal responses to high-dose fentanyl anaesthesia. Br. J. Anaesth. 53:941.

Shatney, C.H., Harmon, J.W., Rich, N.M. (1982a). Hepatic blood flow after canine portasystemic shunting. Ann. Surg. 196: 153.

Shatney, C.H., Harmon, J.W., Rich, N.M. (1982b). Effects of portasystemic shunting on visceral and portal blood flow in the dog. Gastroenterology 83: 1170.

Sherlock, S. (1951). The liver in heart failure. Relation of anatomical, functional and circulatory changes. Br. Heart J. 13:273.

Sherwin, R., Joshi, P., Hendler, R., Felig, P. and Conn, H.O. (1974). Hyperglucagonemia in Laennec's cirrhosis. N. Engl. J. Med. 290: 239.

Sherwin, R. Fisher, M., Bessoff, J., Snyder, N., Hendler, R., Conn, H.O. and Fellig, P. (1978). Hyperglucagonaemia in cirrhosis: altered secretion and sensitivity to glueagon. Gastroenterology 74: 1224 .

Shulman, G.I., Lacy, W. W., Liljenquist, J.E. (1980). Effect of glucose, independent of changes in insulin and glucagon secretion, on alanine metabolism in the conscions dog. $J$. Clin. Invest. 65: 496.

Shumway, N.E. and Lewis, F.I. (1956). Hypothermia and temporary occlusion of the hepatic circulation. National Academy of Sciences, National Research Council, 221.

Sibley, J.A. (1958). Significance of serum aldolase levels. Ann. N.Y. Acad. Sci. 75: 339.

Smitb. G.W., Zug, R.C. and Wilson, S.K. (1967). Periarterial neurectomy of the hepatic artery. An adjunct to portacaval shunt. Am. J. Surg. 113: 117.

Soeters, P.B., Weir, G., Ebeid, A.M. and Fischer, J.E. (1977). Insulin, glucagon, portal systemic shunting, and hepatic failure in the dog. J. Surg. Res. 23: 183.

Soeters, P.B.(1979). Hepatic encephalopathy, a new perspective for therapy. Thesis, University of Limburg, Maastricht, The Netherlands.

Soeters, P.B., Boer de, J.E.G., Oostenbrock, R.J. and Janssen, M.A. (1983). Fate of branched chain amino acids. In: New aspects of clinical nutrition, $G$. Kleinberger and E Deutsch 
(Eds.), Karger, Basel, 337.

Soeters, P. B., Boer de, J.E.G., Oostenbroek, R.J. and Janssen, M.A. (1984). Carbohydrate metabolism in liver disease. In: Hepatic encephalopathy in chronic liver failure, L. Capocaccia, J.E. Fischer and F. Rossi-Faneli (Eds.), Plenum Publishing Corporation, 137.

Stanley, T.H. Berman, L., Green, O. and Robertson, D.H. (1980). Plasma catecholamine and cortisol responses to fentanyll-oxygen anesthesia for coronary-artery operation. Anesthesiology $53: 250$.

Starzl, T.E., Porter, K.A., Watanabe, K. and Putnam, C.W. (1976). Effects of insulin, glucagon, and insulin/glicagon infusions on liver morphology and cell division after complete portacawal shunt in dogs. Lancet 1: 821 .

Strandjord, P.E., Thomas, K.E. and White, L.P. (1959). Studies on isocitric and lactic dehydrogenases in experimental infarction. $\mathfrak{J}$. Clin. In west. 38.2111.

Swenson, O., Grana, L., Inouye, T. and Donnellan, W.L. (1967). Immediate and Iong-term effects of acute hepatic ischemia. Arch. Surg. 95: 451.

Tanturi, C., Swigart, L.L. and Caneda, J.F. (1950). Prevention of death from experimental ligation of the liver (hepatic proper) branches of the hepatic artery. Surg. Gynecol. Obstet. 91: 690 .

Teranaka, M. and Schenk, W. (1977). Hepatic flow measurement. A comparison of the indocyanine green and electromagnetic techniques in normal and abnormal flow states. in the dog. Ann. Surg. 185: 58.

Terblanche, J., Hickman, R., Miller, D.J. and Saunders, S.J. (1975). Animal experiences with support systems: are there appropriate animal models of fulminant hepatic necrosis? In: Artificial liver support, $\mathbb{R}$. Williams and 1 . Murray-Lyon (Eds.), Pitnam, London, 163.

"Thiel, H. (1980). Liver hemodynamics and portacaval shunt. Surg. Gynecol. Obstet. 150: 587.

Tommassini, G. and Presta, M. (1979). Prediction of infarct size by enzymatic techniques; modification of a method and clinical application. Br. Heart J. 42: 326.

Ukikusa, M., Ozawa, K., Shimahara, J, Asano, M., Nakatani, T. and Tobe, T. (1981). Changes in bllood ketone body ratio. Arch. Surg. 116: 781 .

Unger, R.H., Ohneda, A., Aguilar-Parada, E. and Eisentraut, A.M. (1969). The role of aminogenic glucagon secretion in blood glucose homeostasis. J. Clin. Invest. 48: 810 .

Unger, R.H. (1971a). Glucagon physiology and pathophwsiology N Engll I. Med. 28.5.443.

Unger, R.H. (197/b). Glucagon and the insulin: glucagon ratio in diabetes and other catabollic illnesses. Diabetes 20: 834 .

Unger, R.H. and Orci, L. (1981). Glucagon and the A-cell. Physiology and pathophysiology. N. Engl. J. Med. 304: 1518 .

Veen van der, F.H. (1985). St. Thomas Hospital cardioplegia versus intermittent aortic crossclamping in arto-coronary bypass surgery. Thesis, University of Limburg, Maastricht, 1985.

Visser, M.P., Krill, M.T.A., Muijtjers, A.M.M., Willems, G.M. and Hermens, W.T. (1981a). Distribution of enzymes in dog heart and liver. Significance for assessment of tissue damage from data on plasma enzyme activities. Clin. Chem. 27: 1845.

Visser, M.P. , Krill, M.T.A., Willens, G.M. and Hermens, W.T. (1981 b). Selection of a suitable circulatory model for the plasma clearance and distribution of cardiac enzymes in the dog. Cardiovase. Resi, 15: 35.

Visser, M.P., Krill, M.T.A., Willems, G.M. and Hermens, W.T. (1982). Plasma volume determination by use of enzyme dilution in the dog. Lab. Animals 16:248, 
Vorobioff, J., Bredfeldt, J.E. and Groszmann, R.J. (1984). Increased blood How through the portal system in cirrhotic rats. Gastroenterology 87:1120.

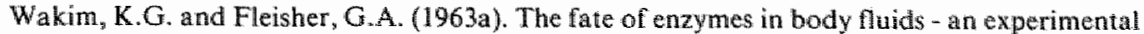
study II. J. Lab. Clin. Med. 61: 86.

Wakim, K.G. and Fleisher, G.A. (1963b). The fate of enzymes in body fluids - an experimental study IV. J. Lab. Clin. Med. 61: 107.

West, M., Eshchar, J. and Zimmerman, H.J. (1966). Serum enzymology in the diagnosis of myocardial infarction and related cardiovascular conditions. Med. Clin. North Am. 50: 171 .

White, T.J., Leevy, C.M., Brusca, A.M., Gnassi, A.M. (1955). The liver in congestive heart failure. Am. Heart J, 49: 250.

Willems, G.M., Muijtjens, A.M.M., Lambi, F.H.H. an Hermens, W.T. (1979). Estimation of circulatory parameters in patients with acute myocardial infarction. Cardiovase. Res. 13: 578 .

Willems, G.M., Visser, M.P., Krill, M.T.A. and Hermens, W.T. (1982). Quantitative analysis of plasma enzyme levels based upon simultaneous determination of different enzymes. Cardiovasc. Res. 16:120.

Willems, G., Veen van der, F.H., Huysmans, H.A., Flameng, W., Meijere de, R., Laarse van der, A., Vusse van der, G.J. and Hermens, W. (1985a). Enzymatic assessment of nyyocardial necrosis after cardiac surgery. Differentiation from skeliatal muscle damage, hemolysis and liver injury. Am. Heart $\mathrm{J}$.

Willems, G.M. (1985b). Assessment of myocandial injury. Thesis, University of Limburg. Maastricht, 1985.

Williamson, D.H. and Mellanby, J. (1974). D-(-)-3-hydroxybutyraat. In: Methoden der enzymatischen analyse, Band II, Bergmejer, H.U. (ed.), Verlag Chenuie, Weinheim, 1883.

Witteveen, S.A.G.J.. Hemker, H.C., Hollaar, L., Hermens, W.T. (1975). Quantitation of infarct size in man by means of plasma enzyme levels. Br. Heart J، 37: 795.

Wustrow, Th., Hoorn-Hickman van, R., Hoorn van, W.A., Vinilk, A.I. ש"ischer, M., Terblanche, J. (1981). Acute hepatic ischaemia in the pig - the changes in plasma hormones, amino acids and brain biochemistry. Hepato-gastroenterol. 28: 143.

Yokota, T. (1979). Functional effect of collateral circulation after dearterialization of the liver. Jap. J. Surg. 9: 335.

Zurick, A.M., Uזzua, J. Estafanous, E.G., Padua, N. and Yared, J.P. (1981). Hemodynamic and hormonal effects of high dose fentanyl versus halothane for cardiac anaesthesia. Anesthesiology 55: A248. 



\section{Nawoord}

Het onderzoek dat in dit proefschrift is beschreven, werd uitgevoerd in het Biomedisch Centrum, Rijksuniversiteit Limburg te Maastricht. Het is een weergave van een deel van de experimenten, die werden verricht in een research periode gedurende de opleiding tot algemeen chirurg aan de afdeling Algemene Heelkunde (hoofd: prof. dr. J.M. Greep) van genoemde universiteit.

Velen hebben bijgedragen tot de verwezenlijking van dit proefschrift. Zonder deze hulp zou het niet tot stand zijn gekomen. De grootste stimulatoren tijdens het bewerken van de behoorlijke hoeveellheid gegevens tot een mogelijk leesbare dissertatie waren de beide co-promotoren, dr. W.Th. Hermens en dr. P.B. Soeters.Peter en Wim, jullie, vanuit de heelkunde en de biofysica toch verschillende wetenschappelijke porte d"entrée, leidde tot een convergentie, vooral als gevolg van een niet aflatende vasthoudendheid, waarbinnen ik soms aanzienlijk divergerende gevoelens ondervond. Behoudens een enkel flink obstakel, hebben jullie met grote inzet en analyserend vermogen zeer veel aan dit proefschrift bijgedragen.

Hooggeleerde Greep, beste Co, je visie op de gezondheidszorg in het algemeen en op het chirurgisch gebeuren in het bijzonder, in ons land zowel als daarbuiten, heeft voor mij verhelderend gewerkt. Mede als gevolg van je visie op hoe een breed opgeleid algemeen chirurg zou moeten functioneren, schiep je de mogelijkheden voor het verrichten van een dergelijke studie. De chirurgie in Maastricht betekent voor mij een periode met dankbare herinneringen.

De referenten, de hooggeleerden Bosman, Flendrig en Wilson, dank ik voor de uitgebreide en kritische kanttekeningen, alsmede voor hun suggesties de duidelijkheid te vergroten.

Marja van Dieijen-Visser legde de initiële link met de lever-geïnteresseerden van de Capaciteitsgroepen Biofysica en Fysiologie. De discussies met 
George Willems werkten altijd stimulerend en legden de beperkingen van klinische research bloot. De samenwerking met Erik van der Veen tijdens het "liver slicen" en de bewerking van de cijfers ten behoeve van hoofdstuk 4 zijn om diverse redenen onvergetelijk. Pim Dassen hielp bij de statistische bewerking.

Het laboratoriumwerk, de radioimmunoassays en de biochemische bepalingen werden nauwgezet verricht door Mieke Janssen, Hans van Eijk, Marie-Louise Boumans en Hennie Goossens. Vooral Mieke heeft op de haar typerende gedegen en accurate wijze honderden bloedmonsters verwerkt. Jurjen de Boer met vooral inhoudelijke, en Johan van Dongen met voornamelijk, maar wel noodzakelijke, niet-inhoudelijke bijdragen, maakten de werkzaamheden aangenaam.

Voorbereiding van operaties, assisteren bij "het shunten", de directe postoperatieve zorg en het kanaliseren van de stemming van de operateur bij enige tegenslag, werden telkens weer verzorgd door Petra Rommers. Ton van den Bogaard hield de vrij stevige vinger aan de vaak voortijdig niet palpabele pols.

Huub Simons, Ruud Kruger, Inger Simons-Achtenberg, Jet Beekman en Theo van der Nagel waren behulpzaam bij de dierexperimenten.

Fré Bosman en Jan-Willem Arends leverden hun bijdrage aan de beschrijving van de histologische preparaten.

De grafieken en figuren werden in eerste instantie door Chris Voskamp, daarna door Alfons Jannink verzorgd.

Marcia van Puijenbroek verrichtte al het typewerk met veel zorg. Marcia, ik dank je voor je toewijding en geduld.

De wetenschap van de altijd aanwezige stimulans, het medeleven en het grote anticiperend vermogen van mijn ouders, vooral tijdens de afgelopen jaren, zijn voor mij een grote ruggesteun geweest. Het is goed dat hier te kunnen vermelden.

Elk proefschrift, dit zeker niet uitgezonderd, vergt aandacht en vaak veel tijd voor degenen die er, in welke hoedanigheid dan ook, bij betrokken zijn geweest. Deze aandacht en tijd is, mogelijkerwijze, dikwijls ten koste gegaan van anderen en andere, wellicht meer belangrijke zaken. Mijn dank voor deze bereidwilligheid is groot. 


\section{Curriculum vitae}

Robert Joannes Oostenbroek was born on the 24 th of July 1946 in Brisbane (Australia).

He attended high school in Amsterdam (H.B.S.-b) and went to Medical School at the University of Amsterdam. In 1974 he was research assistant at the Unit of Pediatric Psychiatry, Department of Pediatrics at the same University. In May 1975 he graduated and became assistant at the Surgical Department (Head Dr. J. Bonnet) of the Bethlehem Hospital, The Hague. His surgical residency was started in February 1976 at the Department of Surgery (Head H.J. van der Reijden) of the Andreas Hospital, Amsterdam. In September 1977 he continued his residency at the Department of Surgery (Head Prof. Dr. J.M. Greep) of the St. Annadal Hospital, University of Limburg, Maastricht. This residency was interrupted from August 1980 - August 1982 for a research fellowship at the Biomedical Centre, University of Limburg, where the experimental work of this thesis was performed. After registration as a surgeon in February 1984 he worked as a 'chef de clinique' at the Department of Surgery of the St. Annadal Hospital, Maastricht. At present, since October 1985, he is surgeon at the Merwede Hospital, Dordrecht. 